UNIVERSIDADE DE SÃO PAULO
FACULDADE DE ZOOTECNIA E ENGENHARIA DE ALIMENTOS

HELENA FAGUNDES

Ocorrência de Staphylococcus aureus e Escherichia coli O157: H7 em rebanhos leiteiros do Estado de São Paulo. 


\section{HELENA FAGUNDES}

\section{Ocorrência de Staphylococcus aureus e Escherichia coli 0157: H7 em rebanhos leiteiros do Estado de São Paulo.}

Tese apresentada à Faculdade de Zootecnia e Engenharia de Alimentos da Universidade de São Paulo, para fins de Defesa para obtenção do Título de Doutor em Zootecnia.

Área de Concentração: Qualidade e Produtividade Animal

Orientador: Prof. Dr. Carlos Augusto Fernandes de Oliveira 


\section{FICHA CATALOGRÁFICA}

preparada pela

Biblioteca da Faculdade de Zootecnia e Engenharia de Alimentos da Universidade de São Paulo

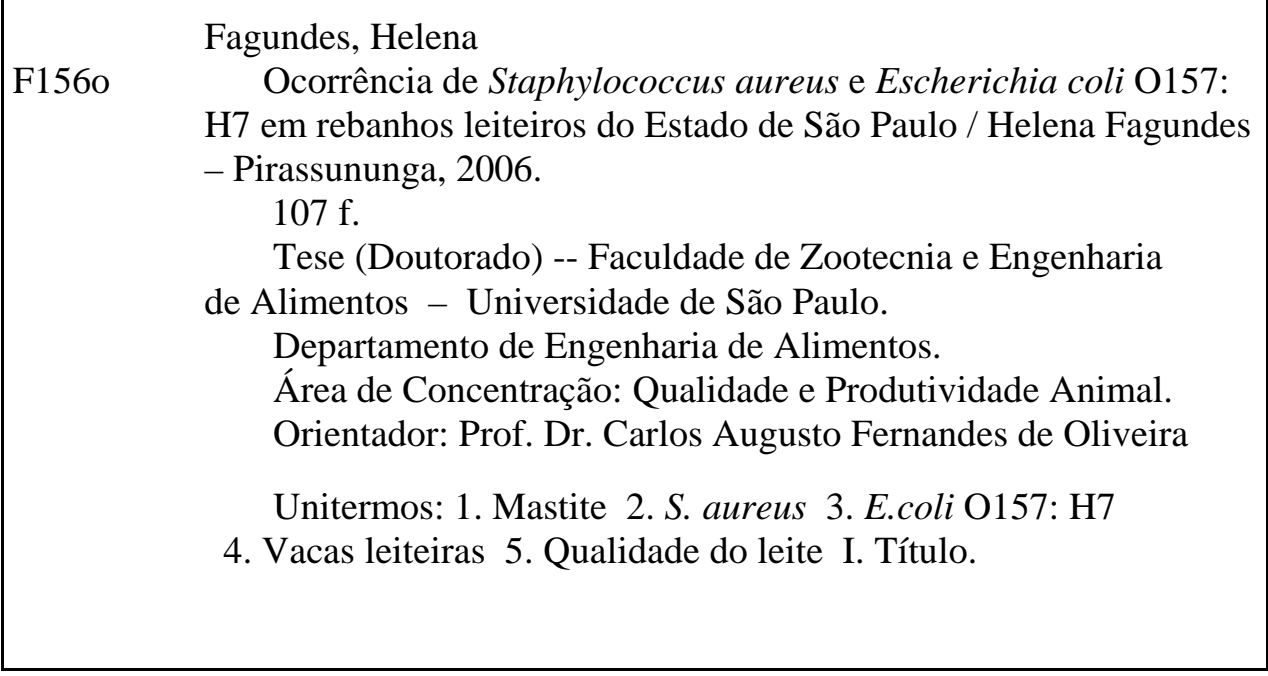


"O valor das coisas não está no tempo em que elas duram, mas na intensidade com que acontecem.

Por isso existem momentos inesquecíveis, coisas inexplicáveis e pessoas incomparáveis".

Fernando Pessoa

Ao J. Henrique, e a nossa pequena Manuella que está a caminho...

DEDICO

"Se eu pudesse deixar algum presente a você, deixaria aceso o sentimento de amor à vida dos seres humanos. A consciência de aprender tudo o que nos foi ensinado pelo tempo afora. Lembraria os erros que foram cometidos, como sinais para que não mais se repetissem. A capacidade de escolher novos rumos. Deixaria para você, se pudesse, o respeito àquilo que é indispensável: alem do pão, o trabalho e a ação. E, quando tudo mais faltasse, para você eu deixaria, se pudesse, um segredo. O de buscar no interior de si mesmo a resposta para encontrar a saída“.

Mahatma Ghandi

Aos meus pais Renato e Leora, por me ensinarem acima de tudo a "ser" antes de "ter"... E a Laura, minha irmã, pelo exemplo de luta e obstinação pelo que deseja e faz... 


\section{AGRADECIMENTOS}

A Deus, por estar sempre segurando minha mão e me indicando o caminho,

Ao meu orientador Carlos Augusto Fernandes de Oliveira pelo exemplo de profissional dedicado e excelente pesquisador,

A Liane, por todo o carinho, dedicação e exemplo de competência profissional.

As minhas amigas, Lu, Laurinha e Erica. "A glória da amizade não é a mão estendida, nem o sorriso carinhoso, nem mesmo a delícia da companhia. É a inspiração espiritual que vem quando você descobre que alguém acredita e confia em você." (Ralph Waldo Emerson).

Ao Saulo pela amizade e "paciência (...)". Aos amigos, Bugio, Andrezza, Evelise e Roice e demais colegas de pós-graduação que tive o prazer de conviver nestes anos.

A aluna de graduação Luciana Barchesi, pela dedicação e ajuda durante todo o período do trabalho.

Ao Professor Antônio Nader Filho, ao colega Luciano Ferreira e ao Laboratório de Medicina Preventiva Veterinária, Universidade Estadual Paulista - UNESP, Campus de Jaboticabal, Estado de São Paulo.

Ao Médico Veterinário Ubiraem Mário Schalch pelo empenho em conseguir produtores de leite interessados em participar do trabalho.

A FAPESP pela bolsa de estudo e ao CNPq pelo auxílio financeiro.

A Faculdade de Zootecnia e Engenharia de Alimentos, FZEA/USP pelas oportunidades e apoio na realização deste projeto.

As 42 propriedades leiteiras que participaram gentilmente deste trabalho. Obrigada pela cordialidade e receptividade! 


\section{LISTA DE FIGURAS}

FIGURA 1: Mapa do Estado de São Paulo com a localização das cidades em que foram coletadas as amostras de leite em um raio de 150 quilômetros.

FIGURA 2: Frascos estéreis de coleta de leite para análise microbiológica (esquerda) e frascos contendo leite e o conservante bronopol para a análise de células somáticas (direita).

FIGURA 3: Fluxograma de análise das amostras de leite individual de vacas leiteiras. .44

FIGURA 4: Fluxograma de análise das amostras de leite de mistura das propriedades leiteiras. .45

FIGURA 5: Petrifilm ${ }^{\circledR}(3 M-$ EUA) com colônias de microrganismos coradas em vermelho. 46

FIGURA 6: Agar Baird Parker com colônias típicas de S. aureus. A seta indica colônias pretas ao centro, circundadas por um halo de precipitação (interno) e outro transparente (externo).

FIGURA 7: Colônias típicas de E. coli O157: H7, sem alteração de cor do meio (sorbitol negativas).

FIGURA 8: Colônias típicas de E. coli O157: H7 (placa a esquerda) sem fluorescência sob luz u.v. (MUG negativa). À direita, colônias MUG positivas (fluorescência a luz u.v.). .48

FIGURA 9: Kit de detecção de toxina TSST-1 (TST - RPLA) e o material utilizado para a execução da técnica. .50

FIGURA 10: Cuba de eletroforese contendo o gel posicionado para a corrida. .52

FIGURA 11: Sistema de ordenha tipo balde ao pé, utilizado principalmente em propriedade leiteira de pequeno e médio porte. .56

FIGURA 12: Sistema de ordenha tipo canalizada em sistema fechado, utilizado geralmente em propriedades leiteiras de grande porte. 
FIGURA 13: Leitura da PFGE do grupo 1 (isolados de S. aureus de 1 a 13). Seqüência da esquerda para direita: padrão lambda, isolados $1,2,3,4,5,6,7,8,9,10,11,12$ e 13, padrão concatâmeros. .80

FIGURA 14: Leitura da PFGE do grupo 2 (isolados de S. aureus 14 a 26). Seqüência da esquerda para direita: padrão lambda, isolados 14, 15, 16, 17, 18, 19, 20, 21, 22, 23, 24, 25 e 26, padrão concatâmeros.

FIGURA 15: Leitura da PFGE do grupo 3 (isolados de S. aureus de 27 a 35). Seqüência da esquerda para direita: padrão lambda, isolados $27,28,29,30,31,32$, 33, 34, 35, padrão concatâmeros. 


\section{LISTA DE TABELAS}

Tabela 1: Resumo das principais características observadas entre as 42 propriedades leiteiras avaliadas nas regiões 1 (São Carlos) e 2 (Ribeirão Preto). .54

Tabela 2: Características gerais das propriedades leiteiras avaliadas na Região de São Carlos, São Paulo.

Tabela 3: Características gerais das propriedades leiteiras avaliadas na Região de Ribeirão Preto, São Paulo. .59

Tabela 4: Distribuição das propriedades leiteiras avaliadas nas regiões 1 (São Carlos) e 2 (Ribeirão Preto) de acordo com a contagem de mesófilos no leite de mistura, através do uso de Petrifilm $®$.

Tabela 5: Distribuição das propriedades leiteiras avaliadas nas regiões 1 (São Carlos) e 2 (Ribeirão Preto) de acordo com a contagem de psicrotróficos no leite de mistura determinado, através do uso de Petrifilm®.

Tabela 6: Distribuição das propriedades leiteiras avaliadas nas regiões 1 (São Carlos) e 2 (Ribeirão Preto) de acordo com a contagem de células somáticas (CCS) no leite de mistura, realizado através da técnica de citometria de fluxo.

Tabela 7: Número de animais amostrados por região e por fazenda e o número de animais positivos encontrado em cada fazenda para Staphylococcus aureus.

Tabela 8: Número de animais amostrados e positivos para Staphylococcus aureus agrupados de acordo com o volume de produção de leite/dia. .65

Tabela 9: Número de animais amostrados positivos para Staphylococcus aureus de acordo com a contagem de células somáticas (CCS).

Tabela 10: Número de animais amostrados positivos para Staphylococcus aureus de acordo com o sistema de ordenha utilizado na propriedade.

Tabela 11: Número de animais amostrados positivos para Staphylococcus aureus de acordo com a prática de pré dipping. 
Tabela 12: Número de animais amostrados positivos para Staphylococcus aureus de acordo com a prática de pós dipping.

Tabela 13: Número de animais amostrados positivos para Staphylococcus aureus de acordo com a prática de uso de luvas descartáveis durante a ordenha.

Tabela 14: Número de animais amostrados positivos para Staphylococcus aureus de acordo com o uso do teste da caneca de fundo preto para detecção de mastite clínica

Tabela 15: Número de animais amostrados positivos para Staphylococcus aureus de acordo com a prática de desinfecção de teteiras com cloro.

Tabela 16: Número de animais amostrados positivos para Staphylococcus aureus de acordo com o tipo de desinfetante utilizado no pré e pós dipping.

Tabela 17: Número de amostras de leite de mistura, positivos para Staphylococcus aureus, agrupados de acordo com a região (1 - São Carlos e 2 - Ribeirão Preto).

Tabela 18: Número de amostras de leite de mistura, positivos para Staphylococcus aureus agrupados de acordo com o volume de leite produzido na propriedade.

Tabela 19: Número de amostras de leite de mistura, positivos para Staphylococcus aureus agrupados de acordo com a contagem de células somáticas.

Tabela 20: Número de amostras de leite de mistura, positivos para Staphylococcus aureus agrupados de acordo com a contagem de aeróbios mesófilos.

Tabela 21: Número de amostras de leite de mistura, positivos para Staphylococcus aureus agrupados de acordo com o tipo de sistema de ordenha utilizado.

Tabela 22: Número de animais amostrados positivos para Staphylococcus aureus de acordo com a prática de pré dipping.

Tabela 23: Número de animais amostrados positivos para Staphylococcus aureus de acordo com a prática de pós dipping.

Tabela 24: Número de animais amostrados positivos para Staphylococcus aureus de acordo com a prática de uso de luvas descartáveis durante a ordenha. 
Tabela 25: Número de animais amostrados positivos para Staphylococcus aureus de acordo com o uso do teste da caneca de fundo preto para detecção de mastite clínica.

Tabela 26: Número de animais amostrados positivos para Staphylococcus aureus de acordo com a prática de desinfecção de teteiras.

Tabela 27: Número de animais amostrados positivos para Staphylococcus aureus de acordo com o tipo de desinfetante utilizado no pré e pós dipping. 76

Tabela 28: Freqüência de detecção de toxinas de isolados de $S$. aureus testados em amostras de leite individual e leite de mistura.

Tabela 29: Perfil bioquímico dos isolados de $S$. aureus positivos para as toxinas estafilococócicas.

Tabela 30: Especificação dos isolados de S. aureus analisados por PFGE no Grupo 1, quanto à fazenda, região e origem da amostra de leite.

Tabela 31: Especificação dos isolados de S. aureus analisados por PFGE no Grupo 2, quanto à fazenda, região e tipo de amostra de leite.

Tabela 32: Especificação dos isolados de S. aureus analisados por PFGE no Grupo 3, quanto à fazenda, região, tipo de amostra de leite.

Tabela 33: Padrões de identificação de Staphylococcus aureus isolados de vacas leiteiras e tanques de resfriamento.

Tabela 34: Número de animais amostrados por região e por fazenda e o número de animais positivos encontrado em cada propriedade para E. coli O157: $\mathrm{H} 7$.

Tabela 35: Número de animais amostrados positivos para E. coli O157: H7 de acordo com o volume de leite produzido na propriedade (L/dia).

Tabela 36: Número de animais amostrados positivos para E. coli $\mathrm{O} 157$ : $\mathrm{H} 7$ de acordo com a contagem de células somáticas (CCS).

Tabela 37: Número de animais amostrados positivos para E. coli $\mathrm{O} 157$ : $\mathrm{H} 7$ de acordo com o sistema de ordenha utilizado na propriedade. 
Tabela 38: Número de animais amostrados positivos para E. coli O157: $\mathrm{H} 7$ de acordo com a prática de pré dipping.

Tabela 39: Número de animais amostrados positivos para $E$. coli $\mathrm{O} 157: \mathrm{H} 7$ de acordo com a prática de pós dipping

Tabela 40: Número de animais amostrados positivos para E. coli O157: $\mathrm{H} 7$ de acordo com a prática de uso de luvas descartáveis durante a ordenha

Tabela 41: Número de animais amostrados positivos para E. coli $\mathrm{O} 157$ : $\mathrm{H} 7$ de acordo com o uso do teste da caneca de fundo preto para detecção de mastite clínica. .89

Tabela 42: Número de animais amostrados positivos para $E$. coli $\mathrm{O} 157: \mathrm{H} 7$ de acordo com a prática de desinfecção de teteiras.

Tabela 43: Número de animais amostrados positivos para E. coli $\mathrm{O} 157$ : $\mathrm{H} 7$ de acordo com o tipo de desinfetante utilizado no pré e pós dipping. .90 


\section{LISTA DE ABREVIATURAS E SIGLAS}

\begin{tabular}{|c|c|}
\hline ANVISA & Agência Nacional de Vigilância Sanitária \\
\hline $\mathrm{BHI}$ & Brain and heart infusion \\
\hline BP & Baird Parker Agar \\
\hline CCS & Contagem de células somáticas \\
\hline CDC & Centers for Disease Control and Prevention - EUA \\
\hline Céls/mL & Células por mililitros \\
\hline CMT & California Mastitis Test \\
\hline CVE & Centro de Vigilância Sanitária \\
\hline DVAs & Doenças veiculadas por alimentos \\
\hline ECDA & E. coli difusamente adesiva \\
\hline ECEagg & E. coli enteroagregativa \\
\hline ECEH & E. coli entero-hemorrágica \\
\hline ECEI & E. coli enteroinvasiva \\
\hline ECEP & E. coli enteropatogênica \\
\hline ECET & E. coli enterotoxigênica \\
\hline ECST & E. coli produtora de shiga-toxina \\
\hline EUA & Estados Unidos da América \\
\hline FDA & Food and Drug Administration \\
\hline IBGE & Instituto Brasileiro de Geografia e Estatística \\
\hline IN 51 & Instrução Normativa 51 \\
\hline L & Litros \\
\hline M & Mol \\
\hline MAPA & Ministério da Agricultura Pecuária e Abastecimento \\
\hline MUG & 4-metillumbeliferil - $\beta$ - D - glicuronídio \\
\hline $\mathrm{ng}$ & Nanograma \\
\hline OMS & Organização Mundial da Saúde \\
\hline PFGE & Eletroforese em gel de Campo Pulsado \\
\hline RPLA & Aglutinação reversa passiva em látex \\
\hline SCT & Síndrome do choque tóxico \\
\hline SET-RPLA & Kit de detecção das enterotoxinas - A, B, C e D \\
\hline $\mathrm{SHU}$ & Síndrome Hemolítica Urêmica \\
\hline stx & Shiga-toxinas \\
\hline TSST-1 & Toxina da síndrome do choque tóxico \\
\hline
\end{tabular}


TST-RPLA Kit de detecção da toxina da síndrome do choque tóxico

TTC 2,3,5 trifeniltetrazólio

UFC/ mL Unidades formadoras de colônias por mililitros

VM

Vermelho de metila

VP

Voges Proskauer 


\section{SUMÁRIO}

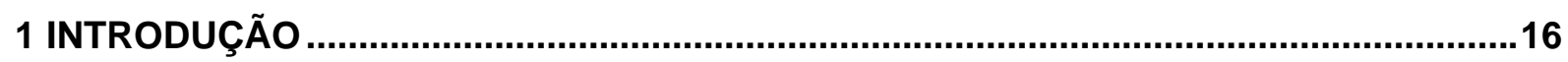

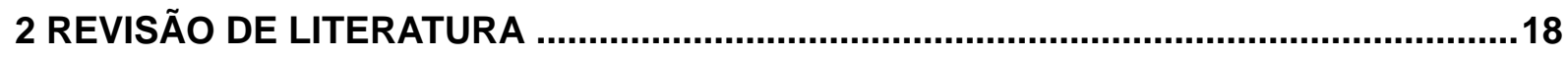

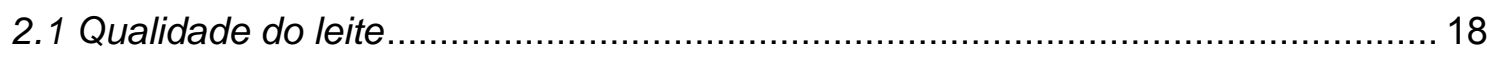

2.2 Doenças veiculadas por alimentos .............................................................. 20

2.3 Importância da mastite na transmissão das DVAs ................................................ 21

2.4 Manejo de ordenha e sua importância no controle da mastite e qualidade do leite .....23

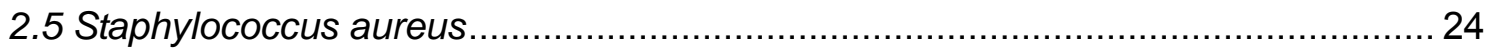

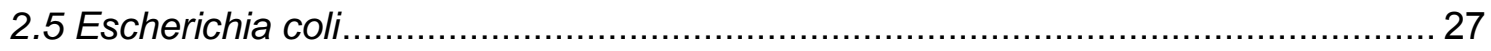

2.6 Características das toxinas produzidas por S. aureus ....................................... 29

2.7 Características das toxinas produzidas pela E. coli. ........................................... 32

2.8 Variabilidade genotípica dos isolados de S. aureus ............................................ 34

2.9 Princípios da eletroforese em gel de campo pulsado ........................................... 35

2.10 Riscos associados à presença de S. aureus e E. coli O157: $\mathrm{H} 7$ no leite .............. 36

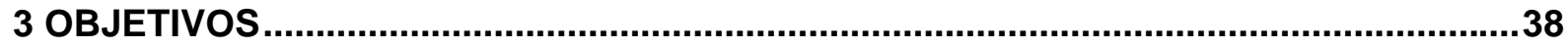

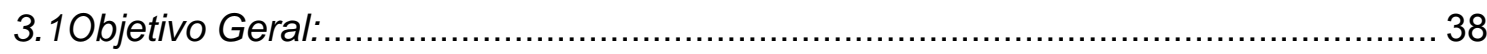

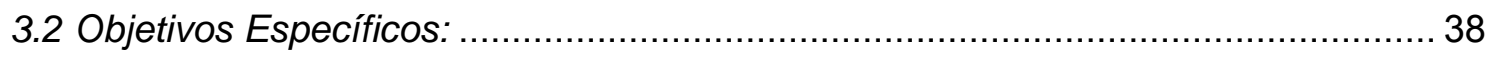

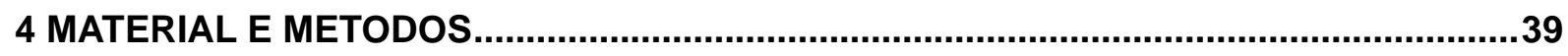

4.1 Caracterização do universo amostral ........................................................... 39

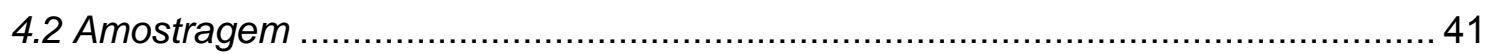

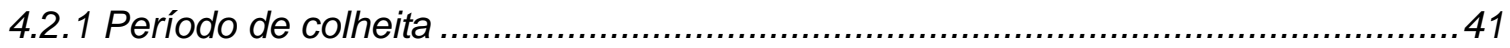

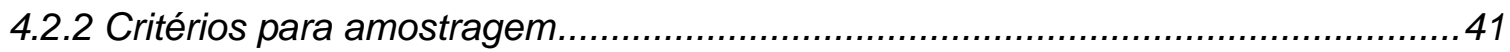

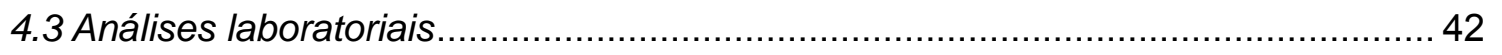

4.3.1 Contagem global de microrganismos...................................................... 42

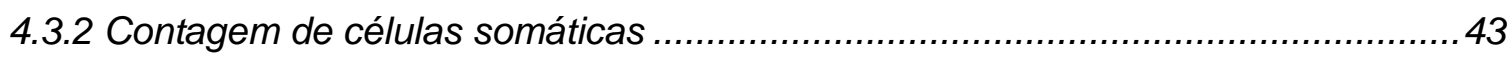

4.3.3 Isolamento e identificação de Staphylococcus aureus........................................46

4.3.4. Isolamento e identificação de Escherichia coli O157: H7 .................................. 47

4.3.5 Detecção das toxinas estafilococócicas.......................................................49

4.3.6. Identificação genotípica dos isolados de S. aureus através da técnica de PFGE 50 4.4 Delineamento experimental e análise estatística. 53 
5.1 Características gerais das propriedades leiteiras avaliadas (Regiões 1 e 2) ..........54

5.2 Parâmetros de qualidade do leite de mistura ........................................................ 61

5.3. Isolamento e identificação de Staphylococcus aureus ....................................... 63

5.3.1 Amostras de leite individuais (vacas leiteiras em produção)................................63

5.3.2 Amostras de leite de mistura (Tanques de expansão) ....................................... 71

5.4 Identificação dos isolados enterotoxigênicos de S. aureus no leite individual e no leite

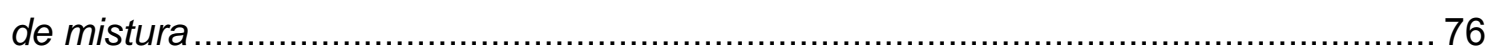

5.5 Identificação genotípica dos isolados de S. aureus................................................ 79

5.6 Isolamento e identificação de Escherichia coli O157: H7 ...................................... 84

5.6.1 Amostras de leite Individual (vacas leiteiras em produção) .................................84

5.6.2 Amostras de leite de mistura (tanques de expansão) ........................................90

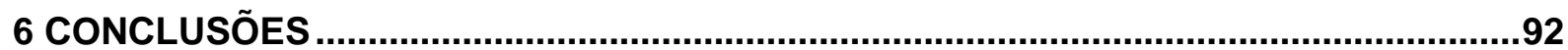

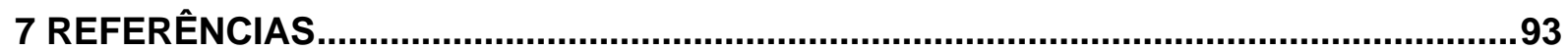




\section{RESUMO}

FAGUNDES, H. Ocorrência de Staphylococcus aureus e Escherichia coli O157: H7 em rebanhos leiteiros do Estado de São Paulo, 2007. 101 f. Tese (Doutorado) - Faculdade de Zootecnia e Engenharia de Alimentos, Universidade de São Paulo, Pirassununga, 2007.

O objetivo deste estudo foi verificar a ocorrência de S. aureus e E. coli O157: H7 no leite de vacas com mastite subclínica e no leite de mistura de 42 propriedades leiteiras localizadas em duas regiões do Estado de São Paulo: São Carlos e Ribeirão Preto. Paralelamente, entre os isolados de $S$. aureus foi objetivo identificar os produtores de toxinas e determinar sua origem epidemiológica. $\mathrm{O}$ isolamento de $\mathrm{S}$. aureus foi realizado em agar Baird-Parker $\left(35^{\circ} \mathrm{C}, 48 \mathrm{~h}\right)$ e a confirmação bioquímica através da catalase, coagulase, termonuclease, produção de acetoína e fermentação aeróbia da maltose. O isolamento de E. coli O157: $\mathrm{H} 7$ foi realizado em agar Sorbitol MacConkey MUG $\left(35^{\circ} \mathrm{C}, 24 \mathrm{~h}\right)$. Para confirmação utilizaram-se as provas do IMVC e sorologia através do kit Soro Anti E. coli O157. Para a detecção da TSST-1 e das enterotoxinas A, B, C e D utilizou-se aglutinação reversa passiva em látex (RPLA). A identificação epidemiológica dos isolados de $S$. aureus foi realizada por eletroforese em gel de campo pulsado (PFGE). A ocorrência de S. aureus no leite individual nas regiões 1 (São Carlos) e 2 (Ribeirão Preto) foram $3,9 \%$ e $6,7 \%$, respectivamente. Animais pertencentes às propriedades leiteiras com produção entre $400 \mathrm{~L}$ e $1.000 \mathrm{~L} /$ dia apresentaram maior risco de veiculação de $S$. aureus através do leite quando comparadas com propriedades com produção $<400 \mathrm{~L} \mathrm{e}>1.000 \mathrm{~L} /$ dia. Quanto ao leite de mistura, verificou-se que a ocorrência de $S$. aureus foi a mesma em ambas as regiões $(19 \%)$. A produção simultânea das enterotoxinas B e C foi observada em $4,7 \%$ dos isolados de leite individual, enquanto que $4,7 \%$ produziram enterotoxina A e toxina TSST-1. A produção de TSST1 , isoladamente, foi constatada em $14,3 \%$ dos isolados de leite individual e em $25 \%$ do leite de mistura. Houve similaridade genética entre os isolados de $S$. aureus, evidenciando sua dispersão epidemiológica entre as propriedades avaliadas. A ocorrência de E. coli O157: H7 no leite individual foi $1 \%$ na região 1 e $1,6 \%$ na região 2 . No leite de mistura não foi detectada $E$. coli 0157: H7. Ressalte-se a importância de medidas preventivas para assegurar a qualidade do leite durante a ordenha, a fim de evitar a ocorrência de microrganismos patogênicos, principalmente S. aureus, e conseqüentemente prevenir riscos de veiculação de toxinfecções através deste alimento.

Palavras-chave: mastite, S. aureus, E. coli O157: H7, vacas leiteiras, qualidade do leite, Saúde Pública. 


\begin{abstract}
FAGUNDES, H. Staphylococcus aureus and Escherichia coli 0157: H7 occurrence in dairy herds located in São Paulo State, 2007. $101 \mathrm{f}$. Thesis (PhD) - Faculdade de Zootecnia e Engenharia de Alimentos, Universidade de São Paulo, Pirassununga, 2007.

The aim of this study was to verify the occurrence of S. aureus and E. coli O157: $\mathrm{H} 7$ in the milk from dairy cows with subclinical mastitis and in the bulk milk from 42 dairy farms located in two regions of São Paulo State (Region 1: São Carlos, Region 2: Ribeirão Preto). Among the $S$. aureus strains isolated, the aim was to identify the toxin producers and their epidemiological origin. The isolation of $S$. aureus was conducted using Baird-Parker agar, and the strains were confirmed by catalase, coagulase, thermonuclease, maltose aerobic fermentation and acetoin production. The isolation of $E$. coli $\mathrm{O} 157$ : $\mathrm{H} 7$ was conducted using Sorbitol MacConkey MUG agar. The strains were confirmed by IMVC and serology using anti E. coli $\mathrm{O} 157$ sera. Rapid passive latex agglutination was used for detection of TSST-1 and enterotoxigenic strains of $S$. aureus. The epidemiological identification was performed using pulsed field gel electrophoresis (PFGE). S. aureus was isolated from $3.9 \%$ and $6.7 \%$ of the individual milk samples from regions 1 and 2, respectively. Dairy cows belonging to farms with milk production ranging from 400 to 1.000 L/day showed higher risk of $S$. aureus carrying-over, when compared with dairy farms with milk production $<400 \mathrm{~L} /$ day and $>1.000$ L/day. In bulk milk samples, the occurrence of $S$. aureus was the same in both regions evaluated (19\%). The simultaneous production of enterotoxin $B$ and $C$ was observed in $4.7 \%$ of strains isolated from individual milk samples, while $4.7 \%$ produced both enterotoxin $A$ and TSST-1. TSST-1 production alone was observed in $14.3 \%$ of $S$. aureus strains isolated from individual milk and $25 \%$ of bulk milk samples. S. aureus strains tested by PFGE demonstrated genetic similarity, showing the dispersion patterns of this microorganism among dairy farms. E. coli $\mathrm{O} 157$ : $\mathrm{H} 7$ was isolated from $1 \%$ and $1.6 \%$ of individual milk samples from regions 1 and 2, respectively, although it was not detected in bulk milk samples. The importance of preventive measures to ensure milk quality during milking extraction is stressed, aiming to avoid pathogenic agents, mainly S. aureus, and therefore, to prevent the carry-over of food borne diseases to humans through milk.
\end{abstract}

Keywords: mastitis, dairy cows, S. aureus, E. coli O157: H7, milk quality, Public Health. 


\section{INTRODUÇÃO}

A produção de leite do Brasil segue em crescente expansão ao longo dos anos. Segundo o IBGE, em 2005 a produção de leite atingiu 25 bilhões de litros, classificando o Brasil, como sexto produtor de leite no mundo. A pecuária leiteira, devido a sua enorme importância social, é uma das mais significantes dentre as atividades ligadas ao agronegócio do país. A atividade é praticada em todo o território nacional em mais de um milhão de propriedades rurais e, somente na produção primária, gera acima de três milhões de empregos e agrega mais de seis bilhões ao valor da produção agropecuária nacional.

Neste contexto, a qualidade da matéria prima tornou-se um dos maiores requisitos para o desenvolvimento e consolidação da indústria de laticínios no Brasil. De modo geral, o controle da qualidade do leite nas últimas décadas tem se restringido à prevenção de adulterações do produto in natura como, por exemplo, a determinação da acidez, índice crioscópico e densidade. A contagem global de microrganismos aeróbios mesófilos, a qual indica a higiene no processo de obtenção do leite, e a contagem de células somáticas, que indica a presença de mastite nos animais, só passaram a serem exigidas com a criação da Instrução Normativa 51 (IN 51) em 2002. Esta norma, implementada oficialmente desde julho de 2005, é constituída pelos regulamentos técnicos sobre produção, identidade e qualidade dos diversos tipos de leite no país, bem como a coleta e o transporte a granel de leite cru refrigerado.

O número crescente e a gravidade das doenças transmitidas por alimentos em todo o mundo, têm aumentado consideravelmente o interesse do público em relação à segurança alimentar. Assim, considerando o leite como alimento básico na dieta humana, principalmente para crianças e idosos, sua qualidade torna-se primordial. O número de doenças associadas ao consumo de leite não tratado termicamente, e o risco de transmissão de agentes patogênicos e seus metabólitos, são fatores importantes uma vez que mais de $40 \%$ da comercialização do leite no Brasil é de origem informal (FARIA, 1998).

As enterotoxinas produzidas por determinadas bactérias nos produtos de origem animal são de extremo interesse devido à ação nociva que causam à Saúde Pública, principalmente porque tais produtos são consumidos na grande maioria das vezes sem fiscalização. O leite e seus derivados, sobretudo aqueles que não sofrem tratamento térmico (pasteurização ou esterilização), podem conter quantidades indesejáveis de microrganismos, capazes de produzir toxinas e provocar conseqüentemente alterações químicas e físicas no produto final. 
A principal doença que acomete as vacas leiteiras é a mastite, definida como a inflamação da glândula mamária, a qual é de origem predominantemente bacteriana. Adicionalmente, a mastite é considerada uma via importante de transmissão de microrganismos para o leite. Na maioria das vezes, os microrganismos presentes no leite cru são destruídos através dos processos térmicos, entretanto, até este momento podem ocorrer alterações na sua composição físico-química decorrentes da presença destes microrganismos, que permanecerão no leite e seus derivados afetando a sua qualidade.

Tendo em vista o exposto, o presente trabalho foi estruturado com a finalidade de verificar a ocorrência de duas bactérias importantes em relação à Saúde Pública e potencialmente causadoras de mastites, o Staphylococcus aureus e a Escherichia coli 0157: $\mathrm{H} 7$, no leite de vacas acometidas de mastite subclínica e no leite de mistura de propriedades leiteiras do estado de São Paulo. 


\section{REVISÃO DE LITERATURA}

\subsection{Qualidade do leite}

O leite e seus derivados desempenham um papel nutricional importante para o homem, particularmente nos primeiros anos de vida, uma vez que fornecem proteínas de alta qualidade, carboidratos, gorduras e sais minerais necessários ao desenvolvimento do organismo. Um litro de leite por dia supre todas as necessidades protéicas de crianças com até seis anos de idade e mais de $50 \%$ do conteúdo de proteínas requisitado pelos adultos. Em relação ao cálcio, o consumo de um litro de leite diário supre $100 \%$ das necessidades diárias deste mineral (COSTA et al. 1995). É de se esperar, portanto, uma grande preocupação em assegurar a integridade e a qualidade intrínseca do leite e dos produtos lácteos destinados ao consumo humano.

O consumo per capita de leite no Brasil em 2005 foi de 138,21 Kg/habitante/ano. Durante dez anos, o consumo oscilou entre 124 e $132 \mathrm{~kg}$ por pessoa por ano. Acima da média mundial, de $80 \mathrm{~kg}$, mas muito abaixo das expectativas recomendadas pelo Guia Alimentar Oficial do Ministério da Saúde (2006), que indiretamente sugere ao redor de 200 $\mathrm{kg} / \mathrm{habitante/ano.}$

O leite é um alimento cuja popularidade é devida principalmente ao seu sabor e, somente se for propriamente obtido e processado, será de boa qualidade.

Segundo Chapaval (1999) as características de um leite de boa qualidade são:

$\checkmark$ Ser livre de todos os microrganismos,

$\checkmark$ Possuir baixa contagem de células somáticas,

$\checkmark$ Ser livre de sedimentos e matérias estranhas,

$\checkmark$ Possuir sabor levemente adocicado e levemente aromático,

$\checkmark$ Ser livre de odores e aromas estranhos,

$\checkmark$ Estar de acordo com os padrões legais, para o mínimo de gordura, sólidos totais e sólidos desengordurados.

Para atingir estes requisitos se faz necessário que o controle seja exercido desde a produção até a distribuição do produto. Assim sendo, testes bacteriológicos, como a contagem de bactérias mesófilas, testes químicos e físicos, juntamente com testes sensoriais devem ser empregados no controle de qualidade, tanto para o leite cru como para o pasteurizado (CARUZO e OLIVEIRA, 1984).

A importância dos microrganismos do leite revela que o conhecimento sobre o seu índice de contaminação microbiana pode ser usado no julgamento de sua qualidade 
intrínseca, bem como das condições sanitárias de sua produção e da saúde do rebanho. Considerando o potencial de se multiplicarem, as bactérias do leite podem causar alterações químicas, tais como a degradação de gorduras, de proteínas ou de carboidratos, podendo tornar o produto impróprio para o consumo e industrialização (COUSIN, 1982).

A qualidade do leite assume destacada importância, também, sob o ponto de vista de Saúde Pública. No Brasil, embora não existam estatísticas bem definidas sobre o assunto, são freqüentes os casos de doenças associadas ao consumo de leite sem tratamento térmico ou de derivados produzidos com leite contaminado com microrganismos patogênicos.

Ao ser extraído da vaca, o leite já contém microrganismos, mas pode, além disso, contaminar-se posteriormente, durante as operações que se seguem até o consumo. Uma grande variedade de organismos pode degradar os constituintes do leite, reduzindo o seu valor para industrialização e consumo. A amplitude dos efeitos vai, desde a redução do tempo de prateleira, até o aumento da rancidez ou uma redução em sua estabilidade. Os custos ou perdas decorrentes destes processos têm um impacto no valor final do produto (SCHMITT, 2003).

O leite é um meio de cultura completo para os microrganismos. Assim, a multiplicação dos microrganismos é muito rápida, se a temperatura for ideal para o crescimento. A contaminação microbiana do leite pode ocorrer por duas vias principais: através da incorporação de microrganismos que estão presentes no úbere, diretamente para o leite, em casos de mastite; ou através do contato do leite com os ordenhadores, utensílios e equipamentos contaminados durante as operações de ordenha, coleta, armazenamento e processamento (CHAPAVAL, 1999).

A indústria leiteira mundial atravessa um período de intensas transformações em sua estrutura, e podem-se identificar como principais tendências a diferenciação do pagamento ao produtor por entregar um leite de melhor qualidade e o aumento nas exigências de qualidade por parte das indústrias, assim como a maior preocupação dos consumidores com relação à segurança alimentar (PRATA, 1998).

A qualidade do leite cru que chega na plataforma da indústria deve ser garantida através da ordenha higiênica de animais sadios e bem alimentados, imediata refrigeração do leite na propriedade e seu transporte a granel em tanques isotérmicos até a indústria (DÜRR, 2006).

Os critérios usados internacionalmente para monitoramento da qualidade do leite foram incorporados recentemente às normas do Ministério da Agricultura Pecuária e Abastecimento (MAPA), por meio da IN 51. A contagem de bactérias totais (CBT) e a 
contagem de células somáticas (CCS) são os parâmetros mais utilizados para a avaliação da qualidade e higiene do leite e situação da mastite nos rebanhos leiteiros, respectivamente.

\subsection{Doenças veiculadas por alimentos}

Inocuidade é a característica ou propriedade dos alimentos de não causar dano à saúde do consumidor. Freqüentemente, alimentos de origem animal, especialmente o leite e seus derivados, estão associados a surtos de toxinfecções alimentares, representando um grande problema à Saúde Pública.

Os conceitos básicos de prevenção e controle da contaminação alimentar e das doenças veiculadas por alimentos (DVAs) sugerem, geralmente, melhorar a qualidade higiênica dos alimentos crus, através da aplicação boas práticas de produção e criação, utilização de tecnologias de processamento e educação de manipuladores. Por isso, o conceito de inocuidade deve ser analisado dentro do conceito geral de qualidade dos produtos lácteos (MONARDES, 2004).

As intoxicações alimentares caracterizam-se pela ingestão de toxinas formadas pela intensa proliferação de microrganismos nos alimentos. Embora as bactérias sintetizadoras de toxinas também sejam usualmente ingeridas, a patogenicidade não se expressa através de uma etapa infecciosa "in vivo". A produção de altas doses de toxinas depende do tipo de contaminação do alimento e das condições oferecidas para a multiplicação de microrganismos como, por exemplo, Clostridium botulinum, Escherichia coli, Staphylococcus aureus e Bacillus cereus (JAY, 1994).

De acordo com o Ministério da Saúde (1999) a contaminação microbiológica do leite e produtos derivados, tem tido pouca importância neste país, mas tem sido foco de atenção em todo o mundo. Com a crescente preocupação por parte dos consumidores mais exigentes quanto à qualidade da dieta alimentar, devemos nos ajustar à nova situação gerada com a modernização da indústria do leite, monitorando os produtos para garantir um alimento sadio.

Dentre os diversos tipos de microrganismos patogênicos que podem ser transmitidos através do leite e derivados, destaca-se o Staphylococcus aureus, cuja importância na epidemiologia das doenças veiculadas por alimentos decorre de sua alta prevalência e do risco de produção, nos alimentos contaminados, de toxinas causadoras de gastrenterites alimentares (ZECCONI e HAHN, 2000).

A intoxicação alimentar abrange todas as classes sociais em todo o mundo. O S. aureus é um dos agentes de destaque devido a vários fatores tais como, a sua ubiqüidade 
na natureza, o baixo nível sócio-econômico dos ordenhadores, muitas vezes portadores assintomáticos de microrganismos patogênicos e possuidores de maus hábitos higiênicos (GILMOUR e HARVEY, 1990), além da elevada prevalência de S. aureus como agente causador de mastite.

A contaminação microbiológica dos alimentos tem sido objeto de preocupação constante em diversos países. Segundo o CDC (2006), nos Estados Unidos da América (EUA), estima-se que, anualmente, 76 milhões de americanos ficam doentes, mais de 300.000 são hospitalizados e 5.000 pessoas morrem em decorrência de doenças transmitidas por alimentos.

No Brasil, segundo dados do Ministério da Saúde (1999), foram registrados 593.212 casos de intoxicação alimentar entre 1984 e 1997, porém sem especificar as toxinas, os microrganismos ou as fontes envolvidas. Estes dados, embora subestimados devido à falta de notificação dos surtos, demonstram a relevância das medidas de controle sanitário dos alimentos destinados ao consumo humano, particularmente das matérias primas de origem animal.

A Escherichia coli O157: H7 é uma causa emergente de DVA. Estima-se que ocorram entre 73.000 casos de infecção a cada ano nos Estados Unidos. A infecção freqüentemente leva à diarréia sanguinolenta e, em 3 a $5 \%$ dos casos leva ao desenvolvimento da Síndrome Hemolítica Urêmica (SHU) (KATSUYA et al. 1998).

De acordo com dados do Centro de Vigilância Epidemiológica (CVE, 2006) do Estado de São Paulo, 70 casos de SHU foram notificados, rastreados e confirmados de 1998 a 2005, a uma média de 8 casos e 0,3 de óbitos ao ano. No entanto não estão relacionados entre os casos os alimentos envolvidos.

\subsection{Importância da mastite na transmissão das DVAs}

O principal problema que afeta os rebanhos leiteiros, mundialmente, é a mastite considerada como a inflamação da glândula mamária. É uma doença freqüentemente de origem bacteriana (COSTA et al. 1995a LANGONI et al. 1998). Mais de 80 diferentes microrganismos já foram identificados como agentes causadores de mastite bovina, sendo que as espécies mais freqüentemente isoladas o Staphylococcus aureus, o Streptococcus agalactiae, o Streptococcus dysgalactiae, o Streptococcus uberis e a Escherichia coli (HARMON, 1994).

A mastite pode ser classificada em clínica e subclínica (PHILPOT e NICKERSON, 1991) sendo que na forma clínica acontecem anormalidades na secreção láctea, tamanho, 
consistência e temperatura da glândula mamária. A forma subclínica é aquela na qual existe a inflamação, porém sem a apresentação de sinais visíveis da doença sendo necessária a análise do leite (contagem de células somáticas) para sua detecção.

A principal característica percebida durante a mastite subclínica da glândula mamária é a elevação da CCS no leite. O leite dos animais não infectados deve apresentar uma CCS menor que 200.000 células $/ \mathrm{mL}$. Quando a CCS esta acima deste valor significa que está havendo resposta inflamatória devido a um processo infeccioso (SMITH et al. 2001). Contagens iguais ou inferiores a 200.000 células $/ \mathrm{mL}$ de leite foram consideradas normais, não acarretando maiores prejuízos ao produtor.

De acordo com o National Mastitis Concil (1996), os rebanhos leiteiros que não adotam medidas de controle para mastite apresentam cerca de $50 \%$ das vacas infectadas, em média, em dois quartos mamários. As estimativas brasileiras apontam valores de $20 \%$ (LANGENEGGER et al. 1970), 38\% (FONSECA, 1992), e até $71 \%$ para a prevalência da doença em rebanhos dos estados de Minas Gerais e São Paulo (COSTA et al. 1999).

A mastite é considerada como a doença que proporciona as maiores perdas econômicas na produção de leite. Estima-se que haja um prejuízo de cerca de US\$1,8 bilhões/ano nos EUA, em função da ocorrência de mastites (NATIONAL MASTITIS CONCIL, 1996). No Brasil, estima-se que, em função da alta prevalência de mastite nos rebanhos, possa ocorrer perda de produção entre 12 e 15\%, o que significa um total de 2,8 bilhões de litros/ano em relação à produção anual média de 20 bilhões de litros (FONSECA e SANTOS, 2000).

No Brasil pode-se afirmar que a forma subclínica ocorre em todos os rebanhos leiteiros. Em levantamento realizado de 1999 a 2003 na Região Sudeste do Brasil por Machado et al. (2003), a prevalência de mastite subclínica nos rebanhos era de aproximadamente $40 \%$. A taxa de novas infecções e infecções crônicas de $22 \%$ e $68 \%$, respectivamente. Estes números mostram, segundo os autores que os animais ficam infectados facilmente, e que, na sua grande maioria, permanecem infectados, resultando em uma alta prevalência da doença.

O limite máximo legal para a CCS do leite nos EUA para produtores individuais (leite de mistura) é de 750.000 células $/ \mathrm{mL}$ e de 500.000 células $/ \mathrm{mL}$ no Canadá. Para países da União Européia, Nova Zelândia e Austrália este limite é de 400.000 células $/ \mathrm{mL}$. No Brasil, a IN 51 estabeleceu que a partir de Julho de 2005, o limite para CCS nas regiões Sul, Sudeste e Centro-Oeste será de 600.000 células $/ \mathrm{mL}$ para leite tipo B e 1.000 .000 células $/ \mathrm{mL}$ para o leite cru refrigerado. 
Existe um grande número de doenças infecciosas que podem ser transmitidas ao homem através do leite. A contaminação do leite extraído da glândula mamária freqüentemente é devido à mastite, resultando em um elevado número de bactérias sendo eliminadas no leite. Uma das grandes preocupações da indústria de alimentos relaciona-se ao controle do desenvolvimento microbiano, visando eliminar os riscos a Saúde Pública, bem como prevenir ou retardar o surgimento de alterações indesejáveis nos alimentos (LANGE e BRITO, 2003).

leite

2.4 Manejo de ordenha e sua importância no controle da mastite e qualidade do

A ordenha envolve um número importante de fatores: a fisiologia e saúde do animal, a mecânica da máquina de ordenha, a qualidade higiênico-sanitária de obtenção do leite e a organização e produtividade da mão de obra (TAVERNA, 2004).

A microbiota presente na superfície externa do úbere é numerosa e variada. $O$ ambiente e as condições de manejo modificam continuamente essa população. Portanto, a quantidade de bactérias existentes sobre a pele dos tetos antes da colocação do conjunto de teteiras para a ordenha, reflete ao mesmo tempo a qualidade do ambiente onde se movimentam ou permanecem os animais e a efetividade das práticas de higiene de ordenha adotadas (TAVERNA, 2004).

As práticas de higiene de ordenha aplicadas antes da colocação das teteiras têm três finalidades: (1) diminuir os riscos de penetração de bactérias patogênicas presentes sobre o teto no interior da glândula mamária, principalmente as de origem ambiental; (2) limitar a contaminação bacteriológica e de sedimentos no leite; (3) contribuir para a estimulação na ejeção do leite.

As rotinas propostas para higienizar os tetos antes da ordenha são múltiplas e variam desde algumas muito simples, que consistem em não fazer nada e colocar as teteiras diretamente, até outras mais complexas, que combinam práticas distintas de lavagem com o uso de desinfetantes e secagem final com papel descartável individual (TAVERNA, 2004).

A higienização dos tetos antes da ordenha contribui para melhorar a qualidade do leite e para prevenir e controlar as infecções da glândula mamária (PANKEY, 1989). Os cuidados higiênicos atualmente recomendados para o período da ordenha baseiam-se em estudos e procedimentos que contemplam o manejo e os equipamentos da ordenha mecanizada (HILLERTON, 1996). 
Dentre as práticas de limpeza de tetos mais recomendadas atualmente estão o pré dipping e o pós dipping, que consistem na imersão dos tetos antes e depois da ordenha, respectivamente em desinfetante próprio. O pré dipping segundo TAVERNA (2004) é o mais importante, pois apresenta bons resultados em relação à contagem bacteriana total e presença de Staphylococcus no leite.

Pedrini e Margatho (2003) afirmam que imergir os tetos cobrindo-os por inteiro com soluções anti-sépticas adequadas é uma das práticas mais importantes e indispensáveis para redução da mastite contagiosa. Já para Jones (1998), o pré dipping reduz novos casos de mastites causadas por coliformes e estreptococos ambientais. Para Goldberg et al. (1994), ocorre uma melhora na condição sanitária da pele do teto e, assim, reduz-se às taxas de infecção da glândula mamária no rebanho. Brito (2000) relata uma redução do número de bactérias na pele dos tetos em mais de $90 \%$ após a mamada do bezerro, se os tetos forem cuidadosamente higienizados.

Os princípios de uma higiene adequada de ordenha ainda incluem o uso de luvas descartáveis pelos ordenhadores, as quais devem ser mantidas limpas ao longo da ordenha, e a utilização de toalhas descartáveis individuais para limpeza dos tetos dos animais antes da ordenha (EDMONDSON, 2002).

A máquina de ordenha, as mãos do ordenhador, práticas de higiene inadequadas e lesões nos tetos são fatores importantes que possibilitam o contato da glândula mamária do animal com microrganismos patogênicos. De acordo com Amaral et al. (2004) a prática de desinfecção de teteiras com cloro entre os animais, durante a ordenha, não é eficiente para diminuir a contaminação na extremidade dos tetos por microrganismos. Os autores observaram que o número de coliformes fecais e Staphylococcus sp. não foi reduzido após o uso desta prática e em alguns conjuntos de teteiras houve aumento do número de microrganismos isolados.

\subsection{Staphylococcus aureus}

O Staphylococcus aureus destaca-se como o microrganismo causador de mastite contagiosa de maior importância, de maior ocorrência nos rebanhos mundiais, e de tratamento mais difícil devido à elevada resistência aos antibióticos. Coerentemente, o S. aureus é, também, o microrganismo patogênico mais freqüentemente isolado no leite cru (ZECCONI e HAHN, 2000).

A contaminação do leite com S. aureus pode ocorrer através das duas vias, uma vez que se trata de um microrganismo patogênico que pode causar inflamações no úbere das vacas, além de estar presente em superfícies de utensílios e equipamentos de ordenha. 
Neste último caso, deve-se ressaltar a importância do homem como reservatório de $S$. aureus e principal veiculador do microrganismo em alimentos (CHAPAVAL, 1999).

Entre as características morfofisiológicas do $S$. aureus, destacam-se as seguintes: são cocos Gram positivos, coagulase positivos, $\beta$-hemolíticos, maltose e manitol positivos (JAY, 1994). Pode apresentar polimorfismo, o que acarreta muitos problemas para o controle das infecções porque afetam diretamente o sistema imunológico da vaca e sua suscetibilidade as infecções.

O S. aureus é classificado como microrganismo mesófilo, porém, pode apresentar crescimento em temperaturas compreendidas entre $7^{\circ} \mathrm{C}$ e $47,8^{\circ} \mathrm{C}$ (JAY, 1994). Por outro lado, as enterotoxinas estafilocócicas são produzidas entre $10^{\circ} \mathrm{C}$ e $46^{\circ} \mathrm{C}$ (SMITH et al. 1983) e apresentam elevada resistência térmica, podendo sobreviver aos tratamentos térmicos comumente aplicados ao leite, como a pasteurização e esterilização.

Em levantamentos epidemiológicos nacionais e internacionais o S. aureus está presente em cerca de $50 \%$ das infecções da glândula mamária dos bovinos leiteiros. Brabes et al. (1999), analisando 127 amostras de leite de cinco propriedades leiteiras dos estados de São Paulo e Minas Gerais, encontraram uma prevalência de 40\% para a espécie S. aureus. Neste mesmo estudo, verificou-se que houve predomínio de bactérias do gênero Staphylococcus sp na etiologia da mastite em 3 propriedades, com percentuais de positividade entre 32 e $80 \%$.

O impacto gerado pela presença deste microrganismo no leite está justamente no risco potencial a Saúde Pública, uma vez que muitos isolados de $S$. aureus são produtores de enterotoxinas potentes. Todavia as enterotoxinas produzidas pelo $S$. aureus também interferem grandemente na patogenia da mastite bovina por serem importantes fatores de virulência e dessa forma causarem danos ao tecido mamário.

Brabes et al. (1999), considerando o isolamento de diversas amostras produtoras de enterotoxinas, indicaram um risco potencial à saúde humana associada ao consumo do leite dos rebanhos analisados. No estudo os autores constataram que a maioria dos casos diagnosticados de mastite era do tipo subclínico, ou seja, de animais que não apresentavam alterações visíveis na glândula mamária e tampouco no leite.

O S. aureus é amplamente distribuído nos rebanhos leiteiros, de forma que a probabilidade de contaminação do leite e conseqüente produção de enterotoxinas são bastante elevadas. Em bovinos, Kenny et al. (1993) relataram que, no mínimo, 28,6\% dos isolados de S. aureus do úbere secretam uma ou mais toxinas. Matsunaga et al. (1993), no entanto, encontraram $34,5 \%$ de isolados enterotoxigênicos. Em cabras, a ocorrência pode 
ser ainda maior, a julgar pelos dados apresentados por Valle et al. (1990), os quais obtiveram $48,8 \%$ de isolados toxigênicos de $S$. aureus oriundos diretamente do leite.

Em um estudo conduzido no Brasil por Mariano et al. (2002), foram coletadas 184 amostras de leite caprino, das quais foram detectadas 36 amostras (19,6\%) contendo bactérias enterotoxigênicas do gênero Staphylococcus, sendo 14 delas (38,8\%) positivas para a espécie $S$. aureus. Os autores concluíram que as enterotoxinas produzidas permanecem no leite pasteurizado graças à sua termoestabilidade, tornando-se um risco em potencial à saúde dos consumidores de leite de cabras.

A produção de enterotoxinas não está restrita unicamente à espécie $S$. aureus. Estudos evidenciaram espécies coagulase negativas, capazes de produzir toxinas em condições laboratoriais, como S. xylosus, S. haemolyticus, S. epidermidis, S. cohnii, S. chromogenes, S. warneri, S. sciuri e S. lentus (PEREIRA et al. 2001). Este fato demonstrou que outras espécies além de $S$. aureus, são capazes de produzir enterotoxinas, embora esta característica já tivesse sido relatada, também, para outras espécies coagulase positivas, como S. hyicus e S. intermedius (VALLE et al. 1999).

Porém não existem estudos conclusivos sobre a relação entre características fenotípicas dos isolados de S. aureus, e sua capacidade de produção de toxinas. Entretanto Matsunaga et al. (1993) têm sugerido que a produção de toxinas seria mais freqüentemente observada em cepas que apresentam maior patogenicidade quando relacionadas às mastites.

O mecanismo utilizado pelo $S$. aureus para invadir e colonizar a glândula mamária dos bovinos e causar processo inflamatório ainda não está bem claro. Sabe-se que a colonização se da através da penetração por via ascendente pelo canal do teto, que após esta entrada ocorrem danos ao epitélio da glândula mamária e conseqüentemente aumento da resposta inflamatória (ALMEIDA et al. 1996).

O S. aureus causador de mastite em bovinos expressa vários fatores de virulência que permite a este microrganismo causar infecções crônicas permanecendo por longos períodos no interior da glândula mamária. As enterotoxinas produzidas pelo $S$. aureus sã o um grupo de fatores de virulência importante que funcionam como superantígenos causando processos inflamatórios graves (EBLING et al. 2001).

Entre esses fatores, destaca-se a toxina 1 da síndrome do choque tóxico (TSST1), reconhecida como a principal causa da síndrome do choque tóxico (TSS) em humanos, caracterizada por febre, hipotensão, congestão em vários órgãos e choque letal (CARDOSO et al. 2000). 
Younis et al. (2003) cita em estudo realizado que dos isolados de S. aureus provenientes de casos de mastite bovina a enterotoxina $C$ foi identificada em 6 a $16 \%$ dos isolados. E de acordo com Matsunaga et al. (1993) a TSST-1, a enterotoxina C, a $\alpha$ hemolisina e a $\beta$-hemolisina contribuem grandemente para a patogenia da mastite, pois são potentes ativadores das células T do sistema imunológico.

De acordo com Bennett (1996), a positividade para a enzima coagulase tem sido usada para indicar patogenicidade dos isolados toxigênicos e a presença da enzima termonuclease, sugerida como indicador mais confiável dessa enterotoxigenicidade. Segundo Bergdoll (1989), se uma cepa apresenta resultados positivos para a produção das enzimas coagulase e termonuclease pode ser considerada como potencialmente produtora de enterotoxina.

Genigeorgis (1989) e Bergdoll (1989) em revisão de diversos trabalhos identificaram o S. aureus, e outras espécies do gênero como enterotoxigênicas. Contradizendo informações de que somente espécies coagulase positiva são enterotoxigênicas e, de que, espécies coagulase negativa são sempre não enterotoxigênicas, não constituindo, portanto risco a saúde pública. Em trabalho desenvolvido por Lamaita et al. (2005) se constatou que dos $24,6 \%$ dos pools de $S$. aureus testados que apresentaram resultado positivo para a prova da coagulase produziram algum tipo de enterotoxina, enquanto $41,3 \%$ dos pools enterotoxigênicos eram coagulase negativa.

Muitos estudos têm sido desenvolvidos para tentar determinar o número mínimo de testes bioquímicos necessários para identificar e diferenciar S. aureus, S. intermedius e S. hyicus (CAPURRO et al. 1999; ROBERSON et al. 1992), no entanto, não existe consenso de quais provas bioquímicas deveriam ser utilizadas para este propósito.

Gandra et al. (2005) com o objetivo de avaliar a eficiência de provas bioquímicas usualmente aplicadas em laboratórios de microbiologia, verificaram que, as cepas isoladas em Agar Baird Parker e Agar P suplementado com acriflavina apresentaram resultados muito variáveis. De forma que os autores chegaram à conclusão que, dentre as provas avaliadas a sensibilidade a acriflavina e a atividade da $\beta$-galactosidade foram as melhores em termos de diferenciação entre espécies, e que as demais provas serviriam apenas com complementares, aumentando a chance de correta identificação.

\subsection{Escherichia coli}

Os problemas de mastite nos rebanhos leiteiros associados com os microrganismos ambientais diferem daqueles causados por patógenos contagiosos. De acordo com Smith e Hogan (1993) os principais patógenos ambientais são as bactérias 
Gram negativas, dentre estes os mais freqüentemente associados com mastite bovina são os coliformes (E. coli, Klebsiella spp., Enterobacter spp).

A mastite por microrganismos da família Enterobacteriacea, geralmente manifesta-se na forma aguda e de curta duração representando um risco à vida do animal (DUNN, 1994). Eberhart (1984) afirmou que a E. coli, a Klebsiella sp e espécies de Enterobacter são as principais enterobactérias causadoras de mastite. Estes patógenos podem se dispersar no ambiente através das fezes e, portanto, o risco de infecção é maior pelo contato com materiais altamente contaminados e equipamentos que não foram limpos adequadamente.

As infecções por $E$. coli na glândula mamária estão relacionadas ao comportamento oportunista do agente, veiculado das fezes dos animais, pela via ascendente, através do canal galactóforo (RADOSTITS et al. 2000).

Shpigel et al. (1998) examinando 978 animais que apresentaram processo clinico de mastite verificaram que a $E$. coli foi o principal microrganismo isolado, identificado em $51,2 \%$ dos casos. Miltenburg et al. (1996), na Holanda, verificaram a E. coli como a principal enterobactéria isolada de casos de mastite, 16,9\% das 1103 amostras de leite.

Considerando a mastite subclínica, Costa et al. (1998) não verificaram diferença entre os níveis de mastite clínica e subclínica por enterobactérias. Porém Cullor (1993) e Dunn (1994), afirmaram que a mastite por enterobactérias geralmente manifesta-se na forma clínica aguda e de curta duração. Entretanto, Bradley e Green (2000), relataram que as enterobactérias são capazes de persistirem no úbere por períodos prolongados podendo recrudescer e determinar mastite clínica. Já Dopfer et al. (1999) afirmaram que infecções persistentes por E. coli ocasionam apenas mastite subclínica.

A E. coli normalmente habita o trato gastrintestinal dos bovinos saudáveis, de modo que o bovino parece ser o principal reservatório do sorotipo 0157: H7. A E. coli O157: $\mathrm{H} 7$ pode se abrigar nas fezes durante um período médio de 21 dias, podendo variar de 5 a 124 dias (FORSYTHE, 2002).

O conteúdo fecal destes animais pode contaminar a glândula mamária das vacas leiteiras e os equipamentos utilizados nos procedimentos de obtenção do leite. A transmissão para humanos ocorre principalmente, por meio de consumo de alimentos contaminados, como carne crua ou pouco cozida e leite não tratado termicamente. $A$ contaminação fecal da água e outros alimentos, bem como contaminação cruzada, durante a manipulação dos alimentos, também pode ser responsável pela transmissão. Há evidências da transmissão deste patógeno pelo contato direto entre pessoas (FORSYTHE, 2002). 
De acordo com o CVE, a E. coli O157: $\mathrm{H} 7$ pode ser encontrada em fazendas de gado e ser isolada de bovinos saudáveis. A carne pode ser contaminada no abate ou durante o processamento inadequado, quando as bactérias intestinais contaminam a carcaça ou quando a carne é moída. A ingestão de leite sem tratamento térmico também tem sido associada a surtos, através da contaminação do úbere das vacas ou dos equipamentos de ordenha com conteúdo fecal.

A E. coli O157: $\mathrm{H} 7$ foi primeiramente reconhecida como causa de doença em 1982 durante estudos epidemiológicos de dois surtos ocorridos de diarréia sanguinolenta severa nos Estados Unidos, que foram associados à ingestão de hambúrgueres (KATSUYA, et al. 1998).

Vários sorotipos de Escherichia coli, como a ECST (E. coli produtora de shigatoxina ou verotoxina - ECVT) grupo no qual pertence o sorotipo 0157: H7 têm sido relacionadas a doenças em humanos. Alimentos de origem alimentar incluindo o leite são notificados como importantes veículos de infecção por ECST em humanos. Está comprovado, segundo o autor, que o sorotipo 0157 : $\mathrm{H} 7$ pode ser isolada das fezes e do leite de animais assintomáticos (JAYARAO e HENNING, 2001).

Crump et al. (2002), descreveram um surto de diarréia por E. coli O157: H7 entre visitantes de uma propriedade leiteira na Pensilvânia, EUA, que permite visita e acesso do público aos animais. Foi realizada uma extensa pesquisa ambiental na fazenda para identificar as fontes da E. coli O157: H7. Como resultado os autores obtiveram que, 51 pacientes com infecção confirmada ou suspeita estavam envolvidos no surto. A média etária dos pacientes foi de 4 anos, e a SHU se desenvolveu em 8 indivíduos. O contato com os animais e seu ambiente foi associado com maior risco de infecção. Os estudos ambientais mostraram que 28 dos 216 animais da fazenda (13\%) estavam colonizados por E. coli 0157 : H7 com o mesmo padrão encontrado na PFGE daquela isolada dos pacientes.

\subsection{Características das toxinas produzidas por S. aureus}

As enterotoxinas produzidas pelo $S$. aureus pertencem a uma grande família de toxinas pirogênicas produzidas tanto por bactérias do gênero Staphylococcus, como Streptococcus, os quais dividem a mesma fisiologia, relação genética, estrutura, função e seqüência homóloga. Estas toxinas podem causar choque tóxico e estão comumente associadas com intoxicações alimentares e diversas formas de alergias e doenças autoimunes (BALABAN e RASOOLY, 2000). 
As enterotoxinas funcionam como potentes toxinas gastrintestinais assim como superantígenos que estimulam a proliferação de células T não específicas. Apesar do modo de ação das enterotoxinas como superantígenos ser muito bem conhecido, pouco se sabe sobre o mecanismo de ação das enterotoxinas como causadoras de gastrenterites em humanos (BALABAN e RASOOLY, 2000). Segundo os autores, uma das hipóteses é que a capacidade enterotoxigênica pode facilitar a transcitose (tráfego de substância dentro de vesículas de um lado para outro do exterior celular), assim possibilitando a interação das toxinas com as células T na corrente sanguínea levando a atividade antigênica.

A sintomatologia observada na maioria dos casos de gastrenterite estafilocócica inclui náuseas, vômitos, contrações abdominais, diarréia, sudorese e cefaléia. A intoxicação geralmente não é letal, sendo que a duração dos sintomas é de 1 a 2 dias podendo evoluir para quadros mais severos, dependendo da susceptibilidade do indivíduo. O período de incubação varia de 1 a 6 horas após a ingestão do alimento contaminado, com média de 4 horas (BALABAN e RASOOLY, 2000).

Com base em métodos sorológicos, identificam-se sete enterotoxinas estafilocócicas, denominadas $A, B, C_{1}, C_{2}, C_{3}, D$ e $E$. São proteínas simples, resistentes à hidrólise pelas enzimas gástricas e jejunais, e estáveis ao aquecimento a $100^{\circ} \mathrm{C}$ durante 30 minutos, não sendo inativadas totalmente pela cocção normal, pasteurização e outros tratamentos térmicos usuais (JAY, 1994). A enterotoxina do tipo A é a mais freqüentemente associada à gastrenterite estafilocócica.

Segundo Cardoso et al. (2000), a produção simultânea de diferentes tipos de toxinas pode aumentar os seus efeitos toxigênicos isolados, sugerindo que essa coprodução possa desempenhar papel importante na patogenia das infecções intramamárias produzidas por esse microrganismo. Refai et al. (1998) demonstraram que existe associação entre a atividade enzimática específica, a enterotoxigenicidade e a resistência de $S$. aureus a vários antibióticos, principalmente naquelas amostras produtoras de mais de um tipo de enterotoxina.

A TSST-1 é um polipeptídeo de cadeia simples, com propriedades biológicas comuns a outras exotoxinas pirogênicas, como capacidade de induzir febre, aumentar a letalidade do choque endotóxico, estimular a proliferação inespecífica de células $T$ e induzir a produção de interleucina-1, de gama interferon e do fator alfa de necrose tumoral (ELLIS et al., 1993).

O primeiro relato de detecção de TSST-1 produzida por Staphylococcus spp. de origem animal foi feito por Jones e Wieneke (1986). Estudos recentes, realizados com S. aureus isolados de casos clínicos e subclínicos de mastite bovina, demonstraram que entre 
$20 \%$ e $77 \%$ dos isolados produziram TSST-1 e enterotoxinas estafilocócicas, respectivamente. Em tanques de expansão utilizados para resfriamento e armazenamento de leite, $75,4 \%$ dos isolados de $S$. aureus demonstraram capacidade de produzir essas toxinas (TAKEUCHI et al. 1998).

Em trabalho realizado por Cardoso et al. (2000), de um total de 127 amostras isoladas de mastite bovina, 83 (65\%) apresentaram produção de pelo menos um tipo de toxina, isolado ou em combinação. Algumas amostras eram produtoras de até quatro toxinas diferentes ao mesmo tempo. Apenas $35 \%$ das amostras testadas foram negativas para qualquer tipo de toxina produzida. Das toxinas identificadas neste trabalho, houve predomínio da TSST-1 e da enterotoxina $D$, em relação às outras enterotoxinas estafilococócicas. Outros pesquisadores, entretanto, associam TSST-1 e a enterotoxina C à amostras causadoras de mastites agudas e subclínicas em bovinos. (JONES e WIENEKE, 1986; MATSUNAGA et al. 1993; TAKEUCHI et al. 1998).

A capacidade de produzir uma ou mais enterotoxinas é encontrada em 30 a $50 \%$ das cepas de S. aureus. Masud et al. (1993), ao examinar 48 linhagens enterotoxigênicas de S. aureus, isoladas de produtos lácteos, observaram que pelo menos 16 delas produziram mais de um tipo de enterotoxina. A enterotoxina mais comumente encontrada foi a do tipo $\mathrm{A}$ (em $37,7 \%$ do total de isolados), seguida pelo tipo B $(17,7 \%)$, D (11,8\%) e C (10,6\%).

A presença de enterotoxinas estafilocócicas no leite e nos produtos lácteos tem sido constatada em diversos estudos. Rosec et al. (1997), analisando queijos elaborados com leite cru, observaram a presença de toxina do tipo C em 73,7\% das 61 amostras analisadas.

$\mathrm{Ng}$ e Tay (1993), estudaram amostras de leite fresco contaminado com S. aureus coagulase positivo. A presença de cepas de $S$. aureus produtoras de enterotoxinas foi constatada em $32,45 \%$ dos isolados, os quais produziram $29,7 \%, 36,1 \%, 22,2 \%$ e $16,7 \%$ das enterotoxinas do tipo $B, C, D$ e $A$ respectivamente.

Segundo Evenson et al. (1988), a quantidade mínima de enterotoxina estafilococócica necessária para causar sintomatologia em humanos é de $200 \mathrm{ng}$. Este valor foi estimado a partir de um surto de gastrenterite atribuído a leite achocolatado, cujas amostras revelaram enterotoxina A no nível médio de 144 ng/embalagem. No episódio, crianças com idade de 5 a 9 anos mostraram maior sensibilidade do que adolescentes de 10 a 19 anos de idade. Calcula-se que, para produzir intoxicação no homem, sejam necessários de 15 a 357 ng de enterotoxina por kg de peso corporal (YI e LEE-WONG, 1997). 
$\mathrm{Na}$ Inglaterra, Bone et al. (1989) relataram que queijos fabricados com leite de ovelhas foram responsáveis por casos de intoxicação alimentar, sendo que as amostras de queijos revelaram a presença de enterotoxina A. Após a realização de análises complementares em amostras de leite e de queijos, os autores concluíram que a contaminação por $S$. aureus ocorreu devido a algum tipo de infecção sofrida pelos animais na fazenda, e não no processo de elaboração dos queijos.

\subsection{Características das toxinas produzidas pela E. coli.}

E.coli O157: H7 pertence a um grupo de cepas patogênicas de E.coli, conhecidas como entero-hemorrágicas (ECEH) ou produtoras de verotoxina (ECVT). Essas linhagens caracterizam-se pela produção de uma toxina chamada de verotoxina (VT) ou "shiga-like" toxina (ST). A VT provoca uma doença chamada colite hemorrágica que, em casos mais graves, resulta em um quadro conhecido como síndrome hemolítica urêmica (SHU) (SILVA, et al. 2001).

A SHU é uma complicação de doença diarréica causada por alimentos contaminados (carne moída, principalmente, mas também água, sucos e verduras) por $E$. coli 0157 e outras produtoras de toxina tipo Shiga, sob vigilância epidemiológica. Assim, como todas as diarréias sanguinolentas, a SHU é de notificação compulsória para que se garanta adequada investigação clínico-laboratorial e epidemiológica dos casos, levantamento de outros casos relacionados, controle e prevenção de possíveis surtos e medidas em relação aos alimentos suspeitos.

No estado de São Paulo, a primeira cepa de E. coli 0157: H7 toxigênica, foi isolada e identificada pelo Instituto Adolfo Lutz (IAL), em julho de 1997. Esta cepa foi isolada a partir de uma amostra de água de poço, de uma chácara localizada em Parelheiros, subdistrito do município de São Paulo. Porém na segunda amostra de água do poço, assim como nas fezes humanas e de animais peri-domiciliares, não foi mais detectada a $E$. coli 0157: H7 (KATSUYA et al. 1998). Embora não tenha sido identificado nenhum caso de infecção humana na área estudada, a detecção deste patógeno em nosso meio torna clara a importância da possibilidade de surtos de diarréia causados por este patógeno emergente.

As cepas ECEH podem pertencer a diferentes grupos sorológicos somáticos e o sorotipo 0157: H7 é o mais importante. O 0157 e o $\mathrm{H} 7$ referem-se à sorotipagem dos antígenos $\mathrm{O}$ (somático) e H (flagelar) da linhagem (FORSYTHE, 2002). 
Investigações de surtos têm demonstrado que a $E$. coli O157: H7 pode ser transmitida através de uma variedade de alimentos, água e através do contato entre pessoas. De acordo com o CVE (2006), na maioria dos surtos descritos, a transmissão ocorre através de alimentos de origem bovina, sendo as carnes moída, crua ou mal passada, implicados em quase todos os surtos documentados e mesmo em casos esporádicos.

Desde que foram descritas a Escherichia coli O157: H7 e outras ECEH tornaram-se conhecidas como os principais agentes causadores de diarréia hemorrágica. Em sentido estrito, o termo ECEH refere-se apenas aos sorotipos que causam a doença clínica idêntica à causada pela $E$. coli $\mathrm{O} 157$ : $\mathrm{H}$, não existindo consenso sobre quando é que uma E. coli produtora de stx pode ser considerada uma ECEH. Entre 5\% a $10 \%$ das pessoas infectadas, sobretudo crianças pequenas e pessoas idosas, desenvolvem complicação grave, como a SHU.

A SHU é caracterizada por anemia e falência renal com uma taxa de letalidade situada entre os $2 \%$ e $7 \%$ e uma taxa de seqüelas em longo prazo, como a insuficiência renal, lesões neurológicas ou hipertensão, de $12 \%$ a $30 \%$. A incapacidade da E. coli 0157 : $\mathrm{H} 7$ em fermentar o sorbitol, tem sido amplamente utilizada como forma de diferenciá-la bacteriologicamente de outras $E$. coli $\mathrm{O} 157$, porém têm sido identificados isolados de $E$. coli O157 que fermentam o sorbitol (AMMON, 1997).

A E. coli é uma espécie heterogênea que inclui muitos biótipos, cepas isoladas de diarréia têm mecanismos de virulência bem definidos, enquanto que cepas isoladas de casos de mastites em animais são associadas com diferentes sorogrupos e não parecem ter potencial patogênico específico (HINTON e BALE, 1991). Porém não se tem conhecimento sobre isolados de $E$. coli produtores de enterotoxinas, principalmente a O157: H7, e sua associação com casos de mastite bovina, não se sabe se estas permanecem no leite e nem a quantidade de toxina produzida.

No entanto, pesquisadores encontraram baixa incidência de doenças causadas por estas toxinas, de 1982 a 1990 somente 14 casos foram confirmados de doenças causadas pela ECST relacionada ao consumo de leite cru nos EUA (ERKSINE et al. 1991). Em estudo conduzido por Jayahao e Henning (2001) a ECST foi isolada de somente cinco num total de $131(3,8 \%)$ amostras de leite de mistura em fazendas leiteiras no estado de Dakota do Sul/EUA.

De acordo com FDA (Food and Drug Administration) dos EUA a dose infecciosa para E. coli O157: H7 é desconhecida. No entanto, a compilação de dados de surtos indica que a dose infecciosa para E. coli O157: H7 menor que dez células. Os dados mostram que 
um pequeno número de microrganismos é capaz de causar doença em crianças jovens, idosos e pessoas imunocomprometidas (FORSYTHE, 2002).

\subsection{Variabilidade genotípica dos isolados de S. aureus}

Existe uma heterogeneidade genética considerável em populações naturais de S. aureus (KAPUR et al. 1995), a qual pode ser explorada para investigar a disseminação do isolados de origem humana e animal.

A avaliação desses traços heterogêneos inclui as variações das características bioquímicas, de sensibilidade a antimicrobianos, a fagotipagem, o perfil da presença de plasmídeos, o estudo das regiões variáveis dos genes da coagulase, da região $X$ da proteína $A$ e do espaçador intergênico entre as regiões $16 S$ e $23 S$ do RNA ribossomal. No entanto, embora existam diferentes métodos para a tipagem de isolados de $S$. aureus, nem todos apresentam eficiência equivalente, no que diz respeito a suas capacidades discriminatórias (FERREIRA, 2004).

A diferenciação dos isolados constitui a base do estudo epidemiológico de doenças infecciosas. Um marcador epidemiológico, por este motivo, deve ser capaz de discriminar os isolados não relacionados, bem como classificar os isolados epidemiologicamente relacionados em um mesmo grupo (FRENAY et al. 1996).

As informações sobre a distribuição dos clones de $S$. aureus nas propriedades de exploração leiteira no Brasil são escassas (SANTOS et al. 2003). Segundo este autor a associação entre os isolados de $S$. aureus provenientes de mastites e os locais de isolamento são de extrema importância epidemiológica. As linhas de ordenha são locais de intenso manejo, que podem propiciar condições de veiculação de patógenos para a glândula mamária, especialmente $S$. aureus, casos sejam negligenciados os procedimentos de desinfecção dos equipamentos de ordenha e de higiene da glândula mamária durante a pré ordenha.

A composição do leite, sua contaminação microbiológica natural e o seu alto grau de manipulação até o processamento, podem explicar o fato dos derivados lácteos serem freqüentemente implicados nas DVAs (TONDO et al. 2000). No Brasil dentre os microrganismos patogênicos, o S. aureus é o mais encontrado no leite cru e também o mais isolado de casos de mastite.

Portanto, do ponto de vista epidemiológico, é de grande importância a determinação da origem dos organismos envolvidos na etiologia da mastite bem como determinar o alimento envolvido nos surtos de DVAs. Neste contexto, a caracterização exata dos patógenos se faz imprescindível para a detecção das vias de transmissão e fontes de 
infecção, além de permitir o monitoramento da disseminação dos isolados entre distintas populações animais (LANGE et al. 1999).

Segundo Bannerman et al. (1995), identificar a origem dos isolados quando da ocorrência de surtos é o maior desafio para determinar a causa do surto e as medidas de controle subseqüentes.

\subsection{Princípios da eletroforese em gel de campo pulsado}

As técnicas empregadas na identificação genotípica de microrganismos, incluindo a diferenciação de espécies e a discriminação de indivíduos de uma mesma espécie, obtiveram grandes avanços nos últimos anos. O desenvolvimento de técnicas moleculares de tipagem de microrganismos abriu novas possibilidades nos campos da classificação, identificação e diagnóstico. O conhecimento sobre a filogenia e evolução dos microrganismos foi também grandemente ampliado (ALVES, 2003).

Atualmente, diversas técnicas fenotípicas e genotípicas são utilizadas em estudos epidemiológicos. Métodos clássicos baseados em características instáveis e subjetivas, têm resultado em variações na expressão fenotípica dos isolados. Bannerman et al. (1995) citam duas técnicas principais utilizadas para este propósito, a PFGE e a tipagem bacteriofágica. Esta última tem sido usada há mais de 30 anos, mas possui várias desvantagens em relação à PFGE, dentre elas a baixa reprodutibilidade, além de não conseguir tipificar todos os isolados. A PFGE é uma técnica molecular que distingue melhor os isolados de $S$. aureus epidemiologicamente relacionados dos não relacionados, além de possuir melhor poder discriminatório, melhor capacidade de identificação e ser de fácil e rápida interpretação (BANNERMAN et al. 1995).

Outras técnicas também têm sido usadas, como a fagotipagem, a análise de restrição do gene da coagulase por meio da reação em cadeia da polimerase (PCR), a RFLP (polimorfismo do comprimento do fragmento de restrição) e a ribotipagem (TENOVER et al. 1994).

A técnica de PFGE por apresentar maior poder discriminatório, quando comparada a outras técnicas, e fornecer resultados mais precisos e exatos, é considerada como técnica "padrão ouro" (Gold Standard), além de ser a mais utilizada pelo CDC - EUA para estudos epidemiológicos (BANNERMAN et al. 1995).

Através da PFGE, técnica que permite a separação de fragmentos de DNA de grande tamanho (desde as centenas de quilobases até as megabases), surgiram novas abordagens ao estudo da organização de genomas. A eletroforese convencional limita a análise de DNA a fragmentos que poderão ter no máximo, 20 a $50 \mathrm{~kb}$, necessitando o uso 
de agarose em baixíssima concentração para a separação de fragmentos de mais de $20 \mathrm{~kb}$. Acima destes tamanhos, não há diferenças de mobilidade que permitam a separação de fragmentos de acordo com o peso molecular (ALVES, 2003).

Com a alternância periódica do campo elétrico, as moléculas são permanentemente forçadas a modificar a orientação em que se movem. Quanto mais longa for a molécula, maior o tempo que necessita para que encontre uma orientação que favoreça o movimento ao longo do gel. Estes são os princípios que determinaram a criação de configurações que permitissem a aplicação de dois campos elétricos, com diferente orientação, a um gel de agarose (ALVES, 2003).

A interpretação dos resultados de PFGE é realizada de acordo com os critérios definidos por Tenover et al. (1995), que consideram três classes de relação entre os isolados: isolados que apresentam até três bandas diferentes são considerados relacionados, isolados apresentando de quatro a seis bandas diferentes são classificados com possíveis relacionados e os isolados que apresentarem sete ou mais bandas diferentes são considerados não relacionados.

\subsection{Riscos associados à presença de S. aureus e E. coli O157: $\mathrm{H} 7$ no leite}

A certificação da qualidade microbiológica do leite apresenta grande importância para a Saúde Pública, uma vez que o leite e seus derivados, quando contaminados, podem originar surtos de toxinfecções alimentares causados por uma variedade de microrganismos que encontram no leite um meio ideal de desenvolvimento. O leite fluido e seus produtos depois de tratados termicamente não constituem uma ameaça aos consumidores, desde que a contaminação microbiana após a pasteurização não ocorra. Isto não se aplica, no entanto, à ocorrência de $S$. aureus e suas toxinas no leite e derivados, tendo em vista que as toxinas podem permanecer estáveis nos produtos oferecidos ao consumo.

Deve-se destacar que a presença de cepas toxigênicas de $S$. aureus no leite cru não implica, necessariamente, na ocorrência de intoxicações em seres humanos, porém o risco existe. A percepção de risco é aumentada, principalmente, ao se considerar que esse microrganismo é o mais envolvido nas infecções intramamárias de rebanhos leiteiros, com prevalência de cepas com elevado potencial toxigênico.

Considerando as características da E. coli O157: H7, seu caráter emergente e sendo o sorotipo mais encontrado e associado a diversos surtos de diarréia em todo o mundo, ressalta-se a importância de um estudo de prevalência desta bactéria no leite bovino, principalmente em animais acometidos de mastite subclínica. 
Tendo em vista a relativa escassez de dados sobre a ocorrência de enterotoxinas estafilocócicas no leite e seus produtos, e da presença de cepas enterotoxigênicas de E. coli no leite de vacas acometidas de mastite, torna-se fundamental a realização de análises microbiológicas periódicas, com vistas à pesquisa de bactérias e suas toxinas no leite entregue nas usinas de beneficiamento. Este critério torna-se ainda mais importante devido ao fato de que o acometimento das vacas por mastite subclínica não resulta em descarte do leite.

A caracterização da origem epidemiológica das cepas de $S$. aureus isolados de rebanhos leiteiros com histórico de mastite é de extrema importância para uma melhor compreensão do padrão de dispersão deste patógeno. Estas informações podem auxiliar de maneira contundente na elaboração de estratégias de controle de mastite e melhorias na qualidade do leite. A partir dos perfis moleculares encontrados é possível inferir as relações genéticas existentes e traçar as rotas de dispersão das infecções.

Portanto, torna-se importante prevenir e controlar as infecções intramamárias nos rebanhos para melhorar a qualidade dos produtos oferecidos à população. A oferta de leite de boa qualidade exige uma série de medidas de controle em todas as etapas da cadeia produtiva. Assim, da mesma forma que produtores de leite e mercado varejista, membros da indústria leiteira (setor de transformação) devem atender à demanda dos consumidores por qualidade e segurança alimentar. Por outro lado, a garantia da qualidade dos produtos lácteos depende, fundamentalmente, das características da matéria prima, ou seja, do leite cru entregue nas plataformas de recepção das usinas de beneficiamento. 


\section{OBJETIVOS}

\subsection{Objetivo Geral:}

Avaliar a ocorrência de Staphylococcus aureus e Escherichia coli O157: H7 em rebanhos leiteiros das regiões de São Carlos e Ribeirão Preto, Estado de São Paulo;

\subsection{Objetivos Específicos:}

* Avaliar a ocorrência de Staphylococcus aureus e Escherichia coli 0157: H7 no leite de vacas acometidas de mastite subclínica e no leite de mistura das propriedades leiteiras;

* Identificar entre os isolados de Staphylococcus aureus:

$>$ Os produtores de enterotoxinas (A, B, C e D) e TSST-1;

> As variações genéticas existentes através da PFGE.

* Avaliar a qualidade do leite de mistura das propriedades leiteiras através da contagem de células somáticas e contagem dos microrganismos aeróbios e anaeróbios facultativos mesófilos e psicrotróficos;

* Verificar a relação das ocorrências de Staphylococcus aureus e Escherichia coli 0157: $\mathrm{H} 7$ no leite individual e de mistura com as condições de ordenha dos animais nas propriedades leiteiras. 


\section{MATERIAL E METODOS}

\subsection{Caracterização do universo amostral}

A amostragem foi definida considerando-se o estudo como sendo descritivo, tratando-se, portanto, de um levantamento epidemiológico para determinar a ocorrência e a distribuição de freqüências de S. aureus e E. coli O157: H7 entre rebanhos leiteiros de duas importantes regiões produtoras de leite do Estado de São Paulo.

Foram utilizadas 42 propriedades leiteiras produtoras de leite $\mathrm{B}$, localizadas a um raio de no máximo 150 quilômetros da cidade de Pirassununga, Estado de São Paulo. As propriedades foram escolhidas de forma aleatória e visitadas somente uma vez durante todo o período do estudo. Como critério de seleção das propriedades utilizou-se a localização das mesmas que, deveriam estar localizadas entre duas regiões de importância na captação de leite, São Carlos e Ribeirão Preto (Figura 1).

As condições gerais de manejo dos animais e higiene de ordenha foram avaliadas através de um questionário (Anexo 1) aplicado em cada propriedade, considerando os seguintes itens: dados de produção leiteira, equipamentos utilizados na ordenha e armazenamento do leite, manejo de ordenha, hábitos de higiene dos ordenhadores, medidas de diagnóstico e prevenção de mastite, rotina de tratamentos e medicamentos habitualmente utilizados em animais com mastite clínica.

A partir das informações obtidas no questionário, foram selecionados os seguintes itens com a finalidade de classificar as propriedades de acordo com as condições gerais de ordenha: (1) mão de obra qualificada (com treinamento), (2) uso de luvas descartáveis durante a ordenha, (3) realização de pré dipping, (4) realização de pós dipping, (5) realização de teste diagnóstico para mastite clínica, (6) limpeza diária das instalações de ordenha com água corrente, (7) ambiente de ordenha calmo sem a presença de outros animais, (8) registro de dados, (9) acompanhamento veterinário e, (10) sala de ordenha com estrutura adequada. As propriedades que atenderam acima de 8 itens foram classificadas como grupo 1 (condições satisfatórias de ordenha), enquanto que as propriedades classificadas como grupo 2 (condições regulares) foram aquelas que atenderam de cinco a oito dos itens. As propriedades classificadas como grupo 3 (condições ruins) foram aquelas que atenderam menos de cinco itens. 


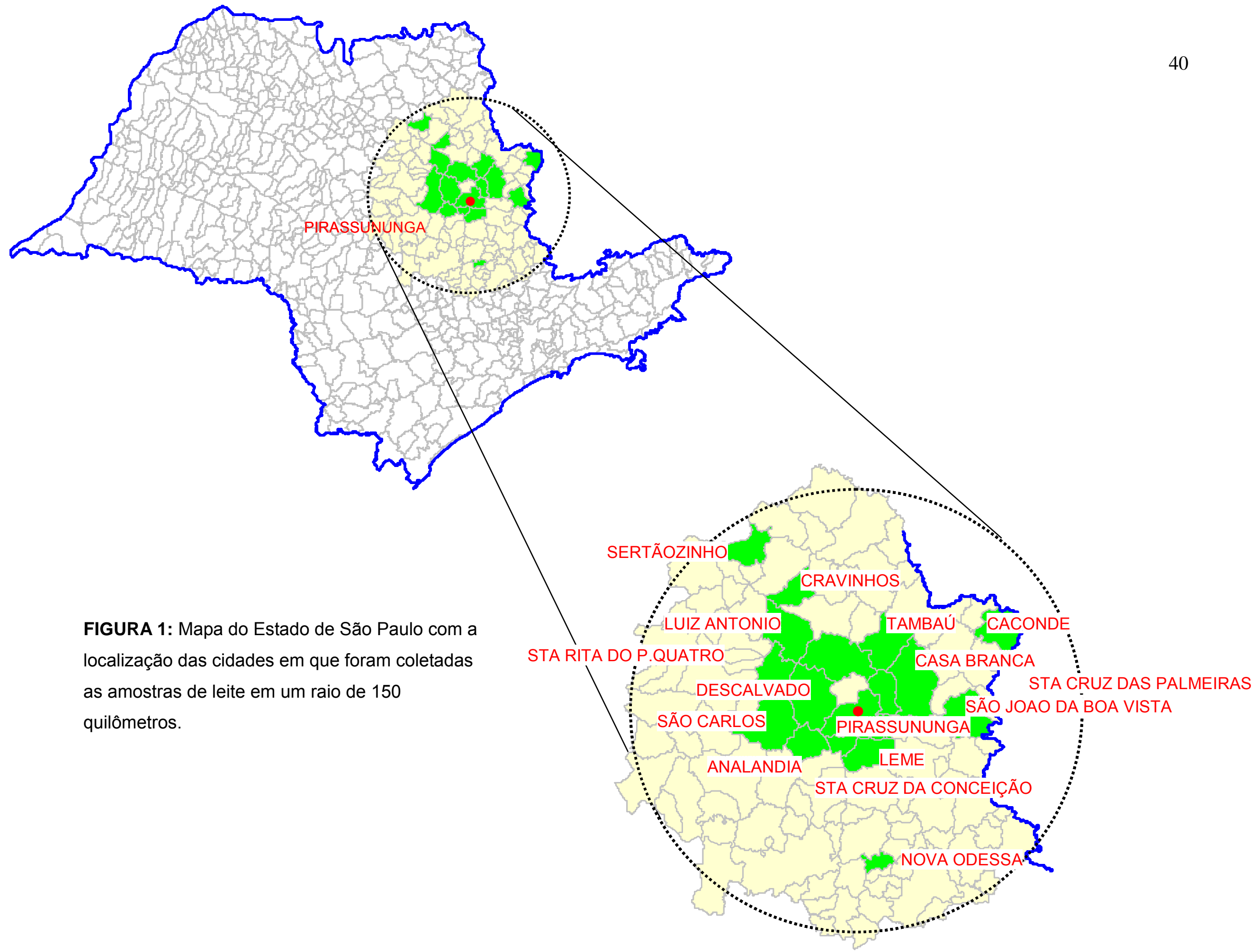




\subsection{Amostragem}

\subsubsection{Período de colheita}

As colheitas das amostras de leite foram realizadas de Fevereiro de 2005 a Março de 2006. As análises laboratoriais foram conduzidas no Laboratório de Microbiologia e Micotoxicologia de Alimentos da Faculdade de Zootecnia e Engenharia de Alimentos/ USP.

\subsubsection{Critérios para amostragem}

As amostras de leite foram colhidas individualmente, de forma composta após a ordenha, de animais que apresentaram mastite subclínica de acordo com o escore de CMT ("Califórnia Mastitis Test"). Coletaram-se duas amostras por animal sendo uma para análise microbiológica e outra para contagem de células somáticas (CCS).

De acordo com Schalm e Noorlander (1957), o teste do CMT é considerado a melhor forma de diagnóstico indireto de mastite subclínica e consiste na comparação do escore de viscosidade da mistura (leite + reagente próprio) e a intensidade do processo inflamatório na glândula mamária. Assim, determinou-se que animais que apresentassem escore maior que um (escala de 0 a 3 , sendo o 0 o escore negativo e 3 o escore máximo de inflamação) seriam os selecionados para a colheita das amostras de leite individual.

Foi avaliada simultaneamente em cada propriedade a presença de mastite clínica, através do teste da caneca de fundo preto, e o resultado anexado à ficha de caracterização de cada propriedade. O teste da caneca foi interpretado segundo os diferentes escores observados nos primeiros jatos de leite retirados da glândula mamária momentos antes do início da ordenha:

$\checkmark \quad$ Escore zero: leite normal (ausência de partículas).

$\checkmark$ Escore um: leite ligeiramente descolorido, com presença de grumos finos e delicados.

$\checkmark \quad$ Escore dois: leite com muitos grumos.

$\checkmark$ Escore três: secreções não semelhantes ao leite, apresentando pus e/ou sangue e/ou fibrina, ou ainda aspecto viscoso, similar ao colostro (WATANABE, 1999).

Finalmente, amostras em triplicata do tanque de resfriamento de cada propriedade leiteira foram colhidas ao término da ordenha e após completa agitação do tanque de mistura durante 10 minutos. Da mesma forma que no leite individual, foram 
coletadas amostras do leite de mistura para análise microbiológica e contagem de células somáticas.

Foram utilizados para colheita das amostras de leite para a análise microbiológica, tubos esterilizados e previamente identificados com o número de cada animal (Figura 2). As amostras foram acondicionadas e resfriadas em recipiente térmico até serem processadas. As amostras não sofreram congelamento para manter um padrão de análise e não haver interferência nos resultados.

\subsection{Análises laboratoriais}

O fluxograma dos procedimentos realizados para isolamento e identificação de S. aureus e E. coli $\mathrm{O} 157$ : $\mathrm{H} 7$ no leite individual das vacas e no leite de mistura, bem como as provas indicativas (contagem em placa de aeróbios mesófilos e psicrotróficos) encontram-se esquematizados nas Figuras 3 e 4, respectivamente. A marcha analítica foi realizada seguindo as recomendações de Silva et al. (2001), adotando-se, complementarmente, os critérios contidos no Bacteriological Analytical Manual (FDA, 2001) para identificação visual e bioquímica das colônias isoladas.

\subsubsection{Contagem global de microrganismos}

Para a contagem de microrganismos aeróbios e anaeróbios facultativos mesófilos e psicrotróficos nas amostras de leite de mistura, foi utilizado Petrifilm ${ }^{\circledR}(3 \mathrm{M}$ EUA) a partir de três diluições, sendo $10^{-3}, 10^{-4}$ e $10^{-5}$ para mesófilos, e $10^{-2}, 10^{-3}$ e $10^{-4}$ para psicrotróficos. As análises destes indicadores foram realizadas apenas nas amostras de leite de mistura, pois o objetivo principal foi avaliar a qualidade do leite como um todo, e não individualmente por animal.

As placas Petrifilm ${ }^{\circledR}$ (Figura 5 ) consistem de cartões de papel quadriculado revestido de polietileno e recoberto com nutrientes desidratados em um gel hidrossolúvel a frio. O sistema é protegido por um filme plástico transparente revestido internamente pelo mesmo gel e um corante indicador (2,3,5 cloreto de trifeniltetrazólio - TTC). Ao adicionar a amostra em teste, os nutrientes são imediatamente re-hidratados, ocorre a solidificação do gel, após o que a placa estará pronta para ser incubada (SANT'ANA et al. 2002).

O TTC é um corante amplamente utilizado em meios de cultura para a enumeração de bactérias, em amostras contendo interferentes. Os microrganismos vivos reduzem o TTC através de enzimas, originando um composto de cor vermelha (formazano) que fica acumulado no interior dos grânulos das células coradas (SANT'ANA et al. 2002). 


\subsubsection{Contagem de células somáticas}

A CCS foi realizada na Clínica do Leite ESALQ/USP - Piracicaba/SP. Utilizaramse frascos plásticos próprios enviados pela Clínica do Leite contendo conservante (Bronopol) (Figura 4). O bronopol é um conservante em forma de pastilha que em contato com o leite, forma esta mistura de coloração rosa claro. Utilizou-se a técnica de citometria de fluxo, através do aparelho Somacount 500 - Bentley.
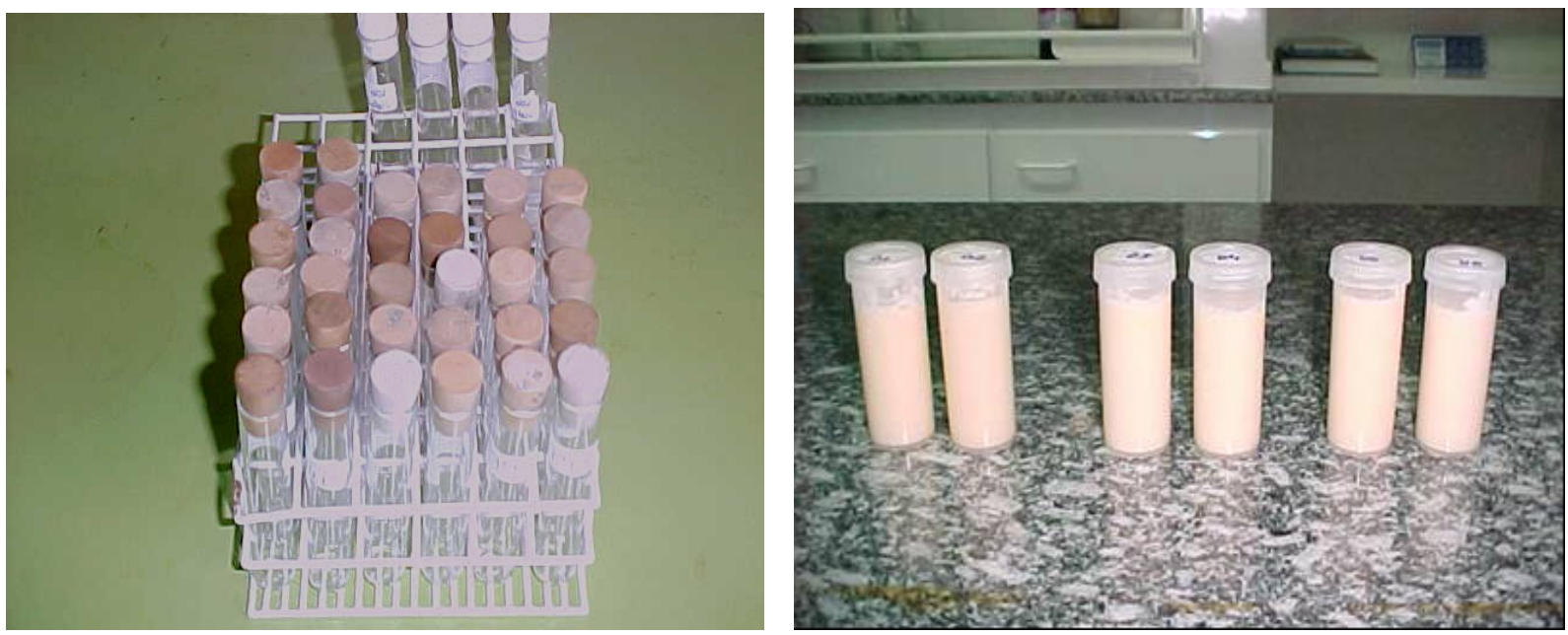

FIGURA 2: Frascos estéreis de coleta de leite para análise microbiológica (esquerda) e frascos contendo leite e o conservante bronopol para a análise de células somáticas (direita).

As amostras de leite individual dos animais e do leite de mistura (triplicata) ficaram sob refrigeração a $4^{\circ} \mathrm{C}$ e foram enviadas para a Clínica do Leite em no máximo três dias após a colheita para serem analisadas.

No Brasil, os equipamentos mais utilizados para realizar contagem de células somáticas são o Fossomatic (Foss Electric - Dinamarca) e o Somacount (Bentley Instruments Incorporated - EUA). Os analisadores eletrônicos baseiam-se em diferentes técnicas de análises, como a contagem de impulsos elétricos gerados pela passagem de partículas entre dois eletrodos, a fluorescência óptica e a citometria de fluxo (BABAK E RYSANEK, 1999).

$\mathrm{Na}$ técnica de fluorescência óptica, o DNA das células é corado e ao ser estimulado por uma fonte de luz, emite fluorescência. A energia emitida é medida como pulsos elétricos e convertida em quantidade de células somáticas presentes na amostra 
(CHRISTEN, 1993). Na citometria de fluxo, as células coradas são carreadas por um líquido sendo excitadas por um feixe de laser. Os núcleos corados emitem, por fluorescência, impulsos luminosos que são ampliados por um foto multiplicador, contados e convertidos em concentração de células somáticas (SILVEIRA et al. 2005)

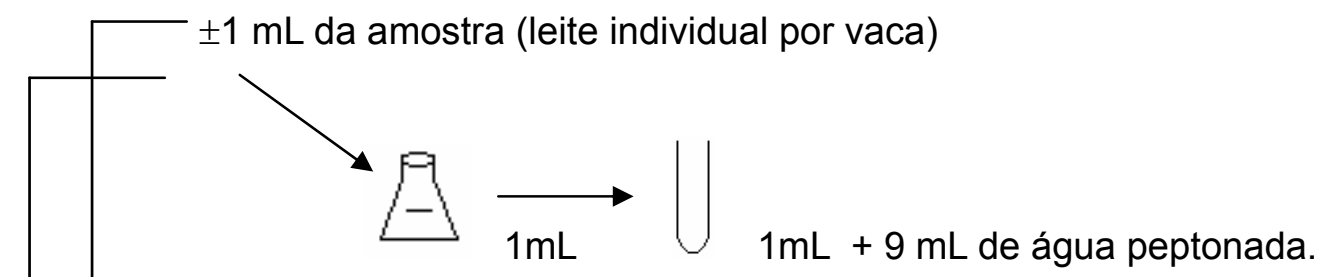

Frasco com leite $\left(10^{-1}\right) \quad 10^{-2}$

\section{Pesquisa de E. coli O157: H7}

$0,1 \mathrm{~mL}$ da diluição $\left(10^{-1}\right)$

$0,1 \mathrm{~mL}$ da diluição $\left(10^{-2}\right)$

$0,1 \mathrm{~mL}$ da diluição $\left(10^{-3}\right)$<smiles>c1ccccc1</smiles>

$10^{-1}$<smiles>c1ccccc1</smiles>

$10^{-2}$

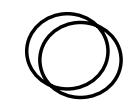

$10^{-3}$
Agar MacConkey Sorbitol MUG (semeadura em superfície). Incubar invertendo as placas a $42^{\circ} \mathrm{C}$ de 18 a 24 horas.
Pesquisa de Staphylococcus aureus

$0,1 \mathrm{~mL}$ da diluição $\left(10^{-1}\right)$

$0,1 \mathrm{~mL}$ da diluição $\left(10^{-2}\right)$
$0,1 \mathrm{~mL}$

$0,1 \mathrm{~mL}$
$0,1 \mathrm{~mL}$

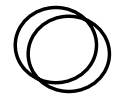

$10^{-1}$

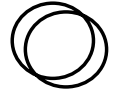

$10^{-2}$
Agar Baird Parker (BP) (semeadura em superfície). Incubar invertendo as placas a $35^{\circ} \mathrm{C}$ por 48 horas.

\section{$0,1 \mathrm{~mL}$ \\ $0,1 \mathrm{~mL}$}
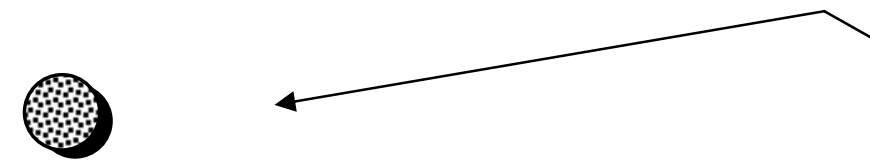

\section{Staphylococcus aureus}

Passar 6 colônias (típicas e atípicas) para caldo BHI (uma colônia por tubo), incubar a $35-37^{\circ} \mathrm{C}$ e esperar 24 horas.

Escherichia coli 0157: H7

\section{Provas Bioquímicas de Identificação}

Catalase (resultado imediato)

Coagulase ( \pm 6 horas)

Termonuclease (1 a 4 horas)

Produção de acetoína (VM-VP) (48 horas)

Passar 6 colônias (típicas) $\int$ Provas Bioquímicas de para caldo MacConkey, e esperar 24 horas. identificação IMVC (indol, vermelho de metila, Voges Proskauer, citrato).

Fermentação aeróbia da maltose (48 horas)

FIGURA 3: Fluxograma de análise das amostras de leite individual de vacas leiteiras. 


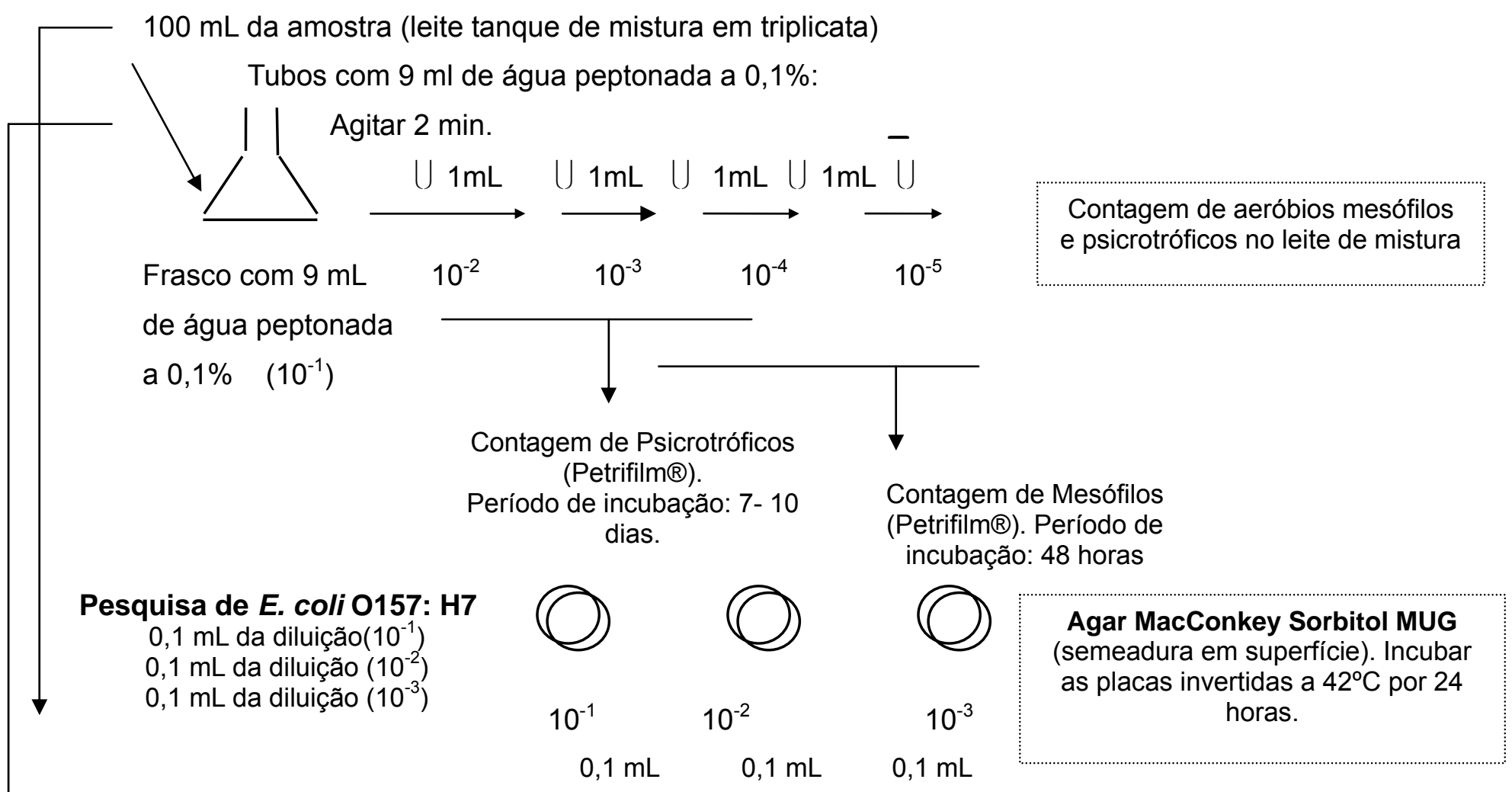

Pesquisa de Staphylococcus aureus

$0,1 \mathrm{~mL}$ da diluição $\left(10^{-1}\right)$

$0,1 \mathrm{~mL}$ da diluição $\left(10^{-2}\right)$

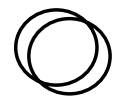

$10^{-1}$

$0,1 \mathrm{~mL}$

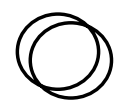

$10^{-2}$

$0,1 \mathrm{~mL}$
Agar Baird Parker (BP) (semeadura em superfície). Incubar as placas invertidas a $35^{\circ} \mathrm{C}$ por 48 horas.

\section{Staphylococcus aureus}

Passar 6 colônias (atípicas e típicas) para caldo $\mathrm{BHI}$ (uma colônia por tubo), e esperar 24 horas.

\section{Provas Bioquímicas de Identificação}

Catalase (resultado imediato)

Coagulase ( \pm 6 horas)

Termonuclease (1 a 4 horas)

Produção de acetoína (VM-VP) (48 horas)

Fermentação aeróbia de maltose (48 horas)
Contagem de aeróbios mesófilos psicrotróficos no leite de mistura 


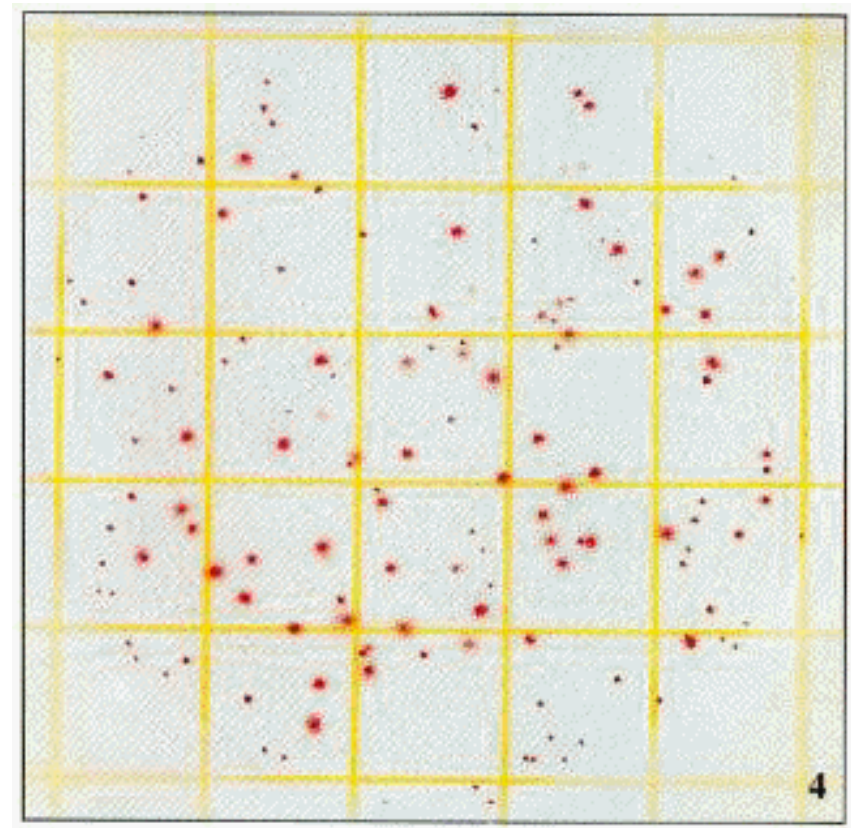

FIGURA 5: Petrifilm® (3M - EUA) com colônias de microrganismos coradas em vermelho.

\subsubsection{Isolamento e identificação de Staphylococcus aureus}

A identificação de Staphylococcus aureus foi realizada em amostras de leite individual das vacas e no leite de mistura, de acordo com Silva et al. (2001). Diluições decimais das amostras $\left(10^{-1}\right.$ e $\left.10^{-2}\right)$ foram semeadas em superfície de placas contendo Agar Baird Parker (BP) (Oxoid) enriquecido com gema de ovo mais telurito de potássio (Oxoid). $\mathrm{O}$ período de incubação utilizado foi $35^{\circ} \mathrm{C}$ por 48 horas.

Para confirmação, foram selecionadas seis colônias, sendo três típicas (colônia preta com halo precipitado e transparente - Figura 6) e três atípicas (colônia descolorida ou preta, sem halo de precipitação), enriquecidas em caldo BHI (Brain and Heart Infusion Oxoid), para primeiramente realizar os testes da catalase, coagulase e termonuclease. Além dessas três importantes técnicas de confirmação bioquímica de cepas de $S$. aureus utilizaram-se mais duas provas de confirmação, a fermentação aeróbia da maltose (incubação a $37^{\circ} \mathrm{C}, 48$ horas) e a produção de acetoína (incubação a $37^{\circ} \mathrm{C}$, 48 horas) (SILVA et al. 2001).

Os isolados de S. aureus são caracterizados por apresentarem reações positivas para catalase, coagulase, termonuclease, produção de acetoína (Voges Proskauer) e fermentação da maltose, sem produção de gás.

Em todas as análises realizadas foi utilizada cepa padrão como controle positivo de S. aureus (ATCC 2592) (Bac-Far, Cefar Diagnóstica Ltda.). 


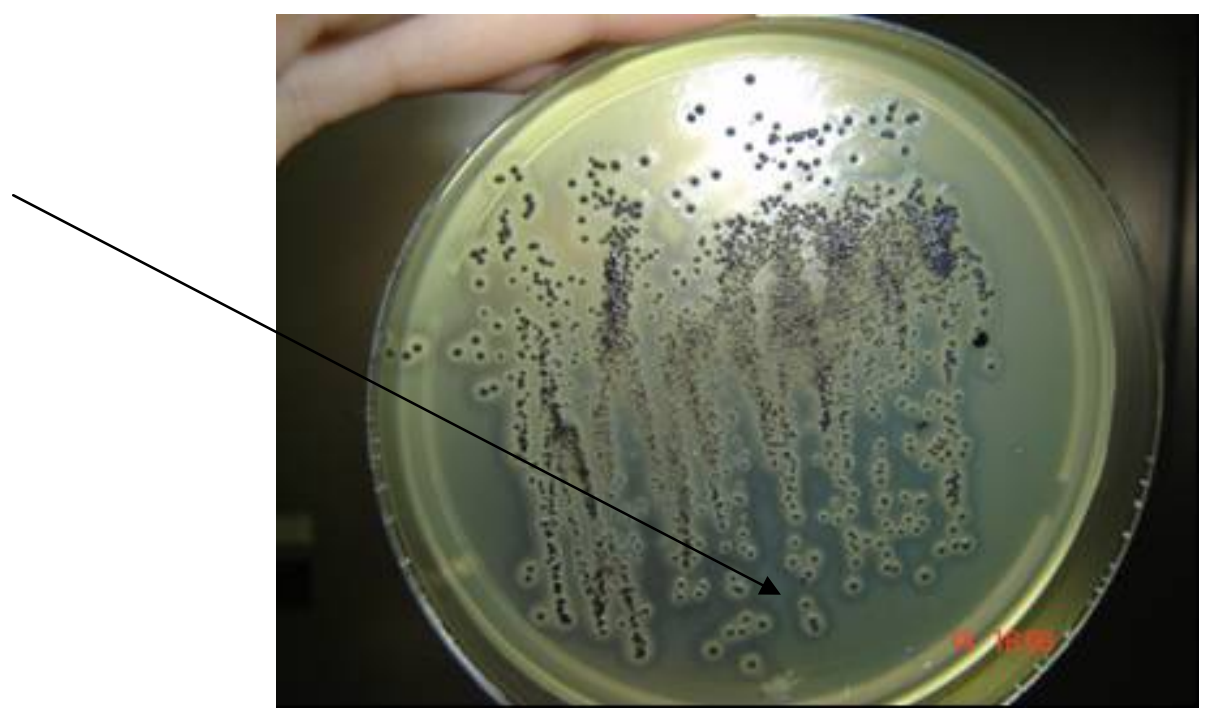

FIGURA 6: Agar Baird Parker com colônias típicas de S. aureus. A seta indica colônias pretas ao centro, circundadas por um halo de precipitação (interno) e outro transparente (externo).

\subsubsection{Isolamento e identificação de Escherichia coli O157: H7.}

Para o isolamento das cepas de E. coli O157: $\mathrm{H} 7$, diluições decimais das amostras $\left(10^{-1}, 10^{-2}\right.$ e $\left.10^{-3}\right)$ foram semeadas em superfície de placas contendo Agar Sorbitol - MacConkey (Difco) + MUG (4 - metilumbeliferil - $\beta$ - D - glicuronídio) (Oxoid) e incubadas a $37^{\circ} \mathrm{C}$. Após 24 horas, as placas foram examinadas para a identificação das colônias sorbitol e MUG negativas, ou seja, sem alteração de cor do meio (sorbitol negativas) e sem fluorescência sob luz u.v. (MUG negativa), de acordo com Massa et al. (1999) (Figura 7 e 8).

Para confirmação, foram selecionadas seis colônias típicas de cada amostra, enriquecidas em caldo peptona caseína-peptona de soja (CASO) (Merck), para os testes do indol, citrato, vermelho de metila e Voges Proskauer (IMVC) (SILVA et al. 2001). Em todas as análises realizadas foi utilizada uma cepa padrão como controle positivo de E. coli O157: H7 obtida no Instituto Adolf Lutz, na seção de Coleção de Culturas.

Os isolados de E. coli O157: H7 são caracterizados por apresentarem reações positivas para indol e vermelho de metila (VM) e reações negativas para Voges Proskauer (VP) e citrato.

Após o isolamento e confirmação bioquímica, os isolados foram submetidos ao teste de sorologia (aglutinação em lâmina) para detectar a presença do antígeno 0157 através do kit Soro Anti E. coli O 157 (Probac), pois somente a identificação bioquímica não é suficiente para caracterizar os isolados como sendo E. coli $\mathrm{O} 157$ : $\mathrm{H}$. O resultado foi 
considerado positivo quando ocorreu formação de uma suspensão completa e homogênea com formação de grumos após 2 minutos de leve agitação manual (EDWARDS e EWING, 1972).

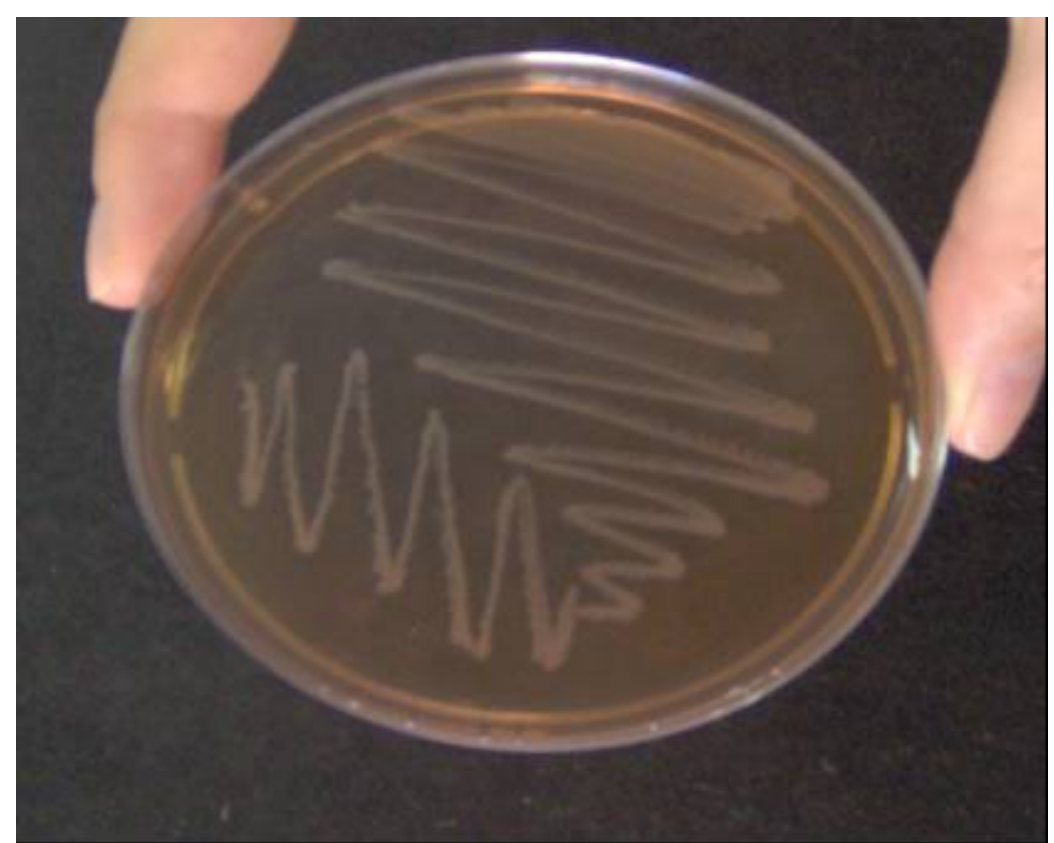

FIGURA 7: Colônias típicas de E. coli O157: H7, sem alteração de cor do meio (sorbitol negativas).

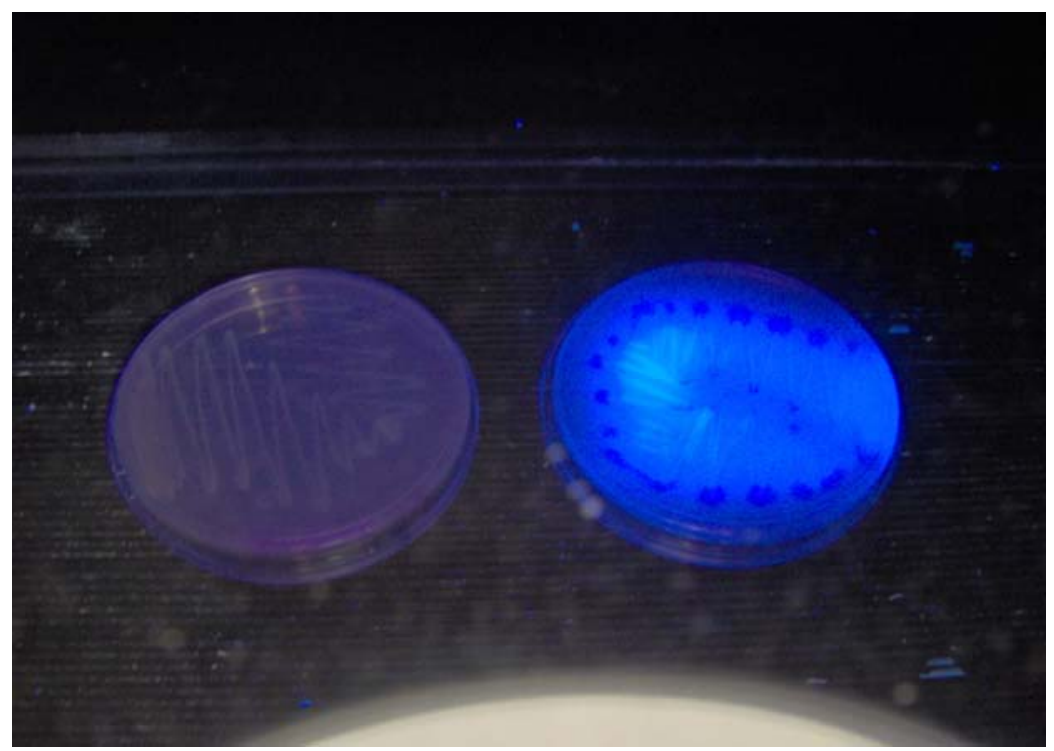

FIGURA 8: Colônias típicas de E. coli O157: H7 (placa a esquerda) sem fluorescência sob luz u.v. (MUG negativa). À direita, colônias MUG positivas (fluorescência a luz u.v.). 


\subsubsection{Detecção das toxinas estafilococócicas}

Foram testadas os isolados de S. aureus, que, de acordo com a série bioquímica foram positivos para as seguintes provas: catalase, coagulase e termonuclease. Após descongelamento estes isolados foram cultivados em $\mathrm{BHI}$ e incubados a $37^{\circ} \mathrm{C}$ por 18 horas em estufa com temperatura controlada.

Para a detecção da TSST-1 (Figura 9) e das enterotoxinas A, B, C e D utilizou-se a técnica de aglutinação reversa passiva em látex (RPLA) descrita por lgarashi et al. (1986) através dos kits TST-RPLA e SET-RPLA (Denka Seiken, Japão), respectivamente. Takeuchi et al. (1998) utilizaram a mesma metodologia para a avaliação das enterotoxinas e da TSST1 em amostras de leite de vacas com mastite e leite de mistura em propriedades no Japão.

Após o período de incubação, transferiu-se $1 \mathrm{~mL}$ do caldo $\mathrm{BHI}$, de cada amostra, para tubos de Eppendorf previamente esterilizado e identificado e as amostras foram submetidas a resfriamento a $4^{\circ} \mathrm{C}$ por 20 minutos. Posteriormente, as amostras foram centrifugadas (Cientec, modelo CT 14000) a 900 x g durante 20 minutos.

Após centrifugação, retirou-se de cada amostra, uma alíquota de $25 \mu \mathrm{l}$ do sobrenadante que foi imediatamente colocado em placas de micro titulação contendo poços cujo fundo possuía formato em " $v$ ". O mesmo volume de látex sensibilizado com imunoglobulinas antitoxinas (TSST-1 e A, B, C e D) foi adicionado em cada poço contendo as amostras.

As placas foram agitadas manualmente em movimentos circulares durante 5 minutos. Após agitação completa, as placas foram tampadas e incubadas em temperatura ambiente por 24 horas para posterior leitura.

O resultado foi considerado positivo quando houve a formação de uma camada difusa do conteúdo no interior da placa, enquanto que a formação de um depósito consistente no fundo do poço da placa de micro titulação foi interpretada como resultado negativo. 


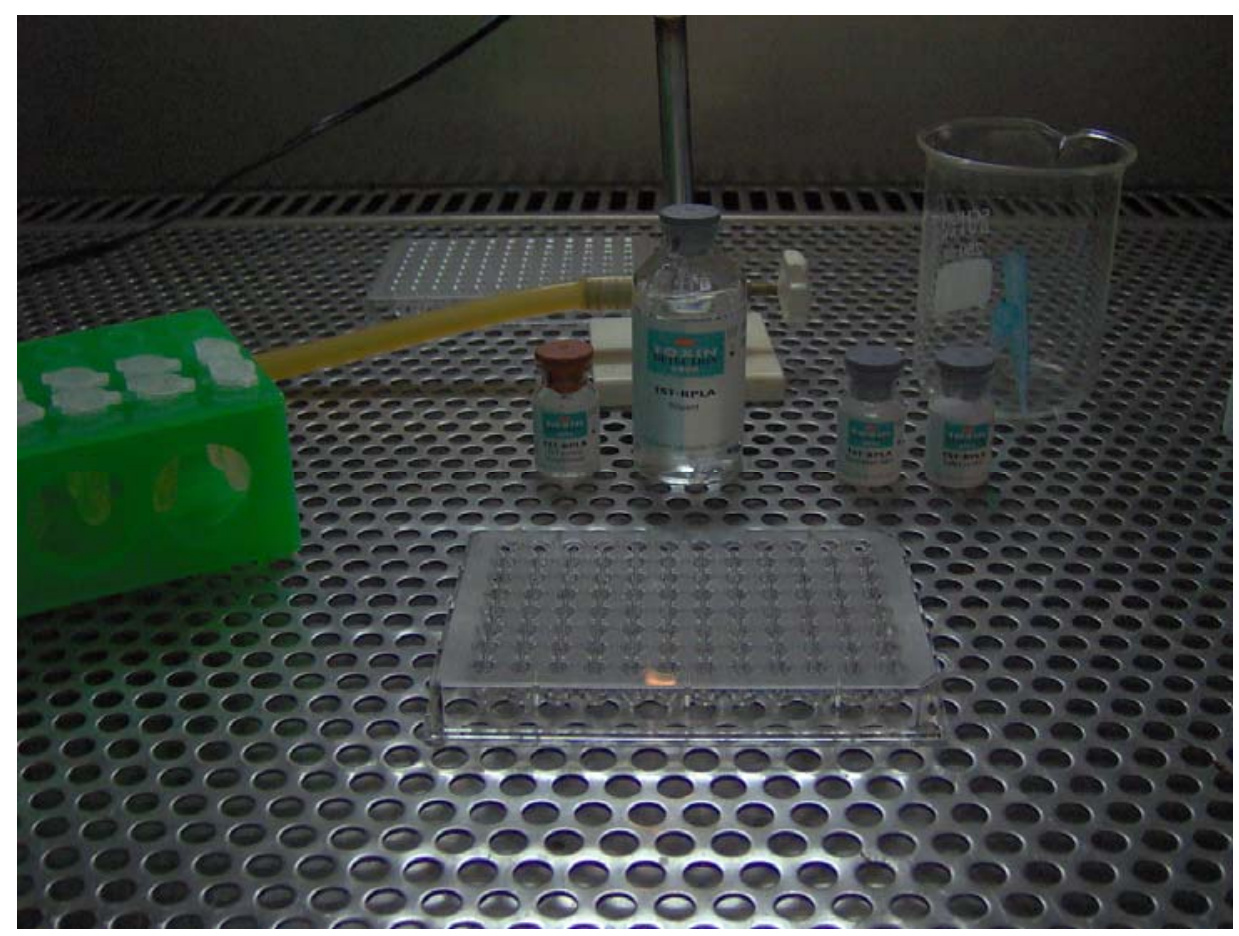

FIGURA 9: Kit de detecção de toxina TSST-1 (TST - RPLA) e o material utilizado para a execução da técnica.

4.3.6. Identificação genotípica dos isolados de S. aureus através da técnica de PFGE

A identificação genotípica de $S$. aureus foi realizada através da técnica de PFGE de acordo com o protocolo estabelecido por McDougal et al. (2003). A análise foi realizada no Laboratório de Medicina Preventiva Veterinária da Universidade Estadual Paulista UNESP, Campus de Jaboticabal, Estado de São Paulo.

Foram selecionados 35 isolados de $S$. aureus ( $66 \%$ do total) para a análise. Foi considerada na escolha dos isolados a origem da amostra (fazenda, leite de mistura ou individual).

Os isolados selecionados foram descongelados (Freezer a $-80^{\circ} \mathrm{C}$ ) e semeados em placas contendo Agar Sangue de Carneiro a $5 \%$ (Acumedia) e incubados a $35^{\circ} \mathrm{C}$ por 24 horas. Em seguida, uma única colônia da placa foi inoculada em $15 \mathrm{~mL}$ de meio Todd-Hewitt Broth (THB) (Sigma - Aldrich), em tubo de centrífuga de $50 \mathrm{~mL}$. Os tubos foram incubados com agitação constante e vigorosa, a $35-37^{\circ} \mathrm{C}$ por 18 - 24 horas, com a tampa levemente aberta, para que a cultura recebesse oxigênio durante a agitação. 
Após a incubação, a concentração bacteriana de cada solução foi ajustada para absorbância 0,6, utilizando solução salina 0,9\% e espectrofotômetro (Thermo Spectronic, modelo Bio Mate 3) com comprimento de onda de $610 \mathrm{~nm}$. Foi transferido $1 \mathrm{~mL}$ da solução ajustada para um tubo de eppendorf e armazenado a $4^{\circ} \mathrm{C}$, como garantia, caso precisasse de repetição a partir desta fase. Da mesma solução, foram transferidos $200 \mu \mathrm{L}$ para outro microtubo e centrifugado a $10.000 \mathrm{rpm}$ a $4^{\circ} \mathrm{C}$ por 10 minutos (Centrifuge 5804R/ Eppendorf). O sobrenadante obtido foi aspirado e ressuspendido em $260 \mu \mathrm{L}$ em tampão TE (10 mM Tris Cl, 5 mM EDTA) (Sigma - Aldrich) e o microtubo foi incubado em banho-maria a $37^{\circ} \mathrm{C}$ por 10 minutos. Em seguida, foi acrescentado $40 \mu \mathrm{L}$ de solução de lisostafina $(1 \mathrm{mg} / \mathrm{mL}$ em 20 mM de acetato de sódio) (Lisostaphin®, Sigma - Aldrich).

Simultaneamente foram preparados os blocos de gel de agarose contendo as amostras a serem testadas. Para a preparação foi utilizada uma solução de $2 \%$ de agarose (BIO-RAD) low-melting em tampão TE (10 mM Tris Cl, 5 mM EDTA) (Sigma - Aldrich) a 55 $65^{\circ} \mathrm{C}$. Posteriormente foi acrescentado $300 \mu \mathrm{L}$ desta solução a cada microtubo com amostra. A solução de cada amostra com agarose foi colocada em moldes para que os blocos fossem formados, deixando solidificar por 10 minutos.

Depois de solidificados, os blocos foram colocados em tubo contendo $3 \mathrm{~mL}$ de tampão de lise EC (6 mM Tris Cl, $1 \mathrm{M} \mathrm{NaCl}$, 0,1 M EDTA, 0,5\% Brij 58, 0,2\% de deoxicolato, $0,5 \%$ de sacosil) (Sigma - Aldrich), e incubados a $37^{\circ} \mathrm{C}$ por 4 horas. Após este período, o tampão de lise foi trocado por $4 \mathrm{~mL}$ de tampão TE por três vezes seguidas, permanecendo 30 minutos em cada troca. Em seguida, a amostra foi colocada em novo tubo e equilibrada com $200 \mu \mathrm{L}$ do tampão $10 x$ (React 4) da enzima Sma I (10U/ $\mu \mathrm{L}$, Invitrogen), a $30^{\circ} \mathrm{C}$ por 30 minutos. Logo após, o tampão foi retirado e acrescentado $200 \mu \mathrm{L}$ de solução com a enzima Sma I, incubando a $30^{\circ} \mathrm{C}$ por 4 horas.

No equipamento de eletroforese (CHEF-DR III System Power Module / Bio-Rad) foi preparado $2,5 \mathrm{~L}$ de tampão TBE $0,5 \mathrm{X}$, separando $100 \mathrm{~mL}$ para a preparação do gel e armazenando o restante a $4^{\circ} \mathrm{C}$ até o momento da utilização. Foi preparado o gel a $1 \%$ de agarose de grau cromossomal, em tampão TBE $0,5 \mathrm{X}$, acrescentando $10 \mu \mathrm{L}$ de brometo de etídio.

Após a solidificação do gel, as amostras foram colocadas nos poços formados pelo pente na posição vertical. No primeiro e no último poço foram colocados os marcadores de pesos moleculares para PFGE (lambda e concatâmeros), e todos foram cobertos com solução de agarose $1 \%$. 
$\mathrm{Na}$ cuba de eletroforese foi adicionado o tampão TBE $0,5 \mathrm{X}$, e o aparelho foi programado para as condições de pulso de 5 a 40 segundos, voltagem de $6 \mathrm{~V} / \mathrm{cm}$, por 21 horas a $14^{\circ} \mathrm{C}$ (Figura 10$)$.

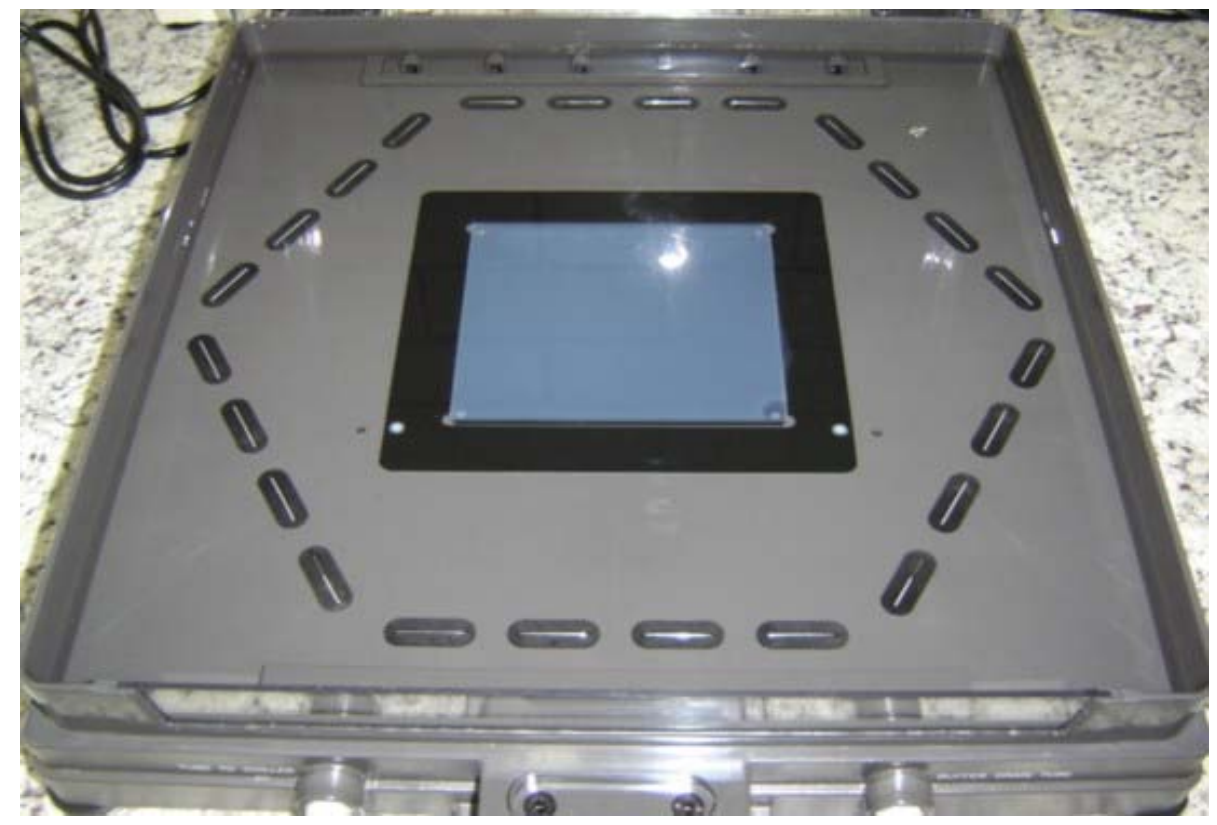

FIGURA 10: Cuba de eletroforese contendo o gel posicionado para a corrida.

Após este período, o gel foi corado com brometo de etídio $(1,5 \mu \mathrm{g} / \mathrm{mL})$ por 45 minutos, em $200 \mathrm{~mL}$ de tampão TBE 0,5X, sob leve agitação. Em seguida, o gel foi descorado com água destilada por 25 minutos. A leitura foi realizada em aparelho de fotodocumentação (Universal Hood II / Bio-Rad).

A capacidade discriminatória foi determinada de acordo com o índice numérico descrito por Hunter e Gaston (1988), para determinar a habilidade do teste em diferenciar os isolados sem relação epidemiológica. $O$ valor $(D)$ indica a probabilidade de duas cepas isoladas de forma aleatória, em uma população-teste, estarem relacionadas em grupos distintos através do método de tipagem avaliado (FERREIRA, 2004).

A fórmula foi utilizada para o cálculo dos valores $D$, sendo (s) número total de tipos (padrões) diferentes, $\left(n_{j}\right)$ número de isolados representativos de cada padrão e $(N)$ número de isolados na população-teste.

$$
D=1-\frac{1}{N(N-1)} \sum_{j=1}^{s} n_{j}\left(n_{j}-1\right)
$$




\subsection{Delineamento experimental e análise estatística}

O desenho experimental utilizado caracterizou-se como um estudo de dispersão de freqüência, o qual é também conhecido como survey ou levantamento epidemiológico (JEKEL et al. 1999). Neste contexto, as hipóteses propostas inicialmente para este estudo foram:

$H_{0}=$ Ocorrência de S. aureus e E. coli O157: H7 no leite de vacas acometidas de mastite subclínica e no leite de mistura de propriedade leiteiras amostradas.

$H_{1}=$ Não ocorrência de S. aureus e E. coli O157: H7 no leite de vacas acometidas de mastite subclínica e no leite de mistura de propriedade leiteiras amostradas.

A ocorrência de S. aureus e E. coli O157: $\mathrm{H} 7$ foi avaliada de acordo com as seguintes variáveis, selecionadas e distribuídas em categorias:

- Região: Categorias: 1 (São Carlos) ou 2 (Ribeirão Preto);

- Produção de leite: Categorias: abaixo de 400 L, 400 a 1.000 L ou acima de 1.000 L;

- Contagem de células somáticas: Categorias: abaixo de 200.000 células $/ \mathrm{mL}$ ou acima de 200.000 células $/ \mathrm{mL}$;

- Sistema de ordenha: Categorias: Sistema balde ao pé ou sistema canalizado (sala de ordenha);

- Prática de pré dipping: Categorias: sim ou não;

- Prática de pós dipping: Categorias: sim ou não;

- Uso de luvas descartáveis durante a ordenha dos animais: Categorias: sim ou não;

- Uso do teste da caneca de fundo preto para detecção de mastite clínica: Categorias: sim ou não;

- Desinfecção das teteiras após a ordenha do animal: Categorias: sim ou não;

- Tipo de desinfetante utilizado na desinfecção dos tetos dos animais: Categorias: iodo, cloro ou nenhum;

- Contagem de bactérias mesófilas (leite de mistura): Categorias: abaixo de 500.000 UFC/mL ou acima de $500.000 \mathrm{UFC} / \mathrm{mL}$.

Aos resultados obtidos no estudo, foi aplicado o teste " $Z$ " de duas proporções, com aproximação normal, para verificar a existência ou não de diferenças significantes entre as freqüências de $S$. aureus e E. coli $\mathrm{O} 157$ : $\mathrm{H} 7$ nas categorias de variáveis selecionadas. Adotou-se, como nível de rejeição, alfa igual a 0,05 e o valor crítico de "Z" de alfa igual a 1,96 (BERQUÓ et al. 1981). 


\section{RESULTADOS E DISCUSSÃO}

5.1 Características gerais das propriedades leiteiras avaliadas (Regiões 1 e 2)

$\mathrm{Na}$ Tabela 1 encontra-se disposto um resumo das principais características observadas entre as 42 propriedades leiteiras produtoras de leite $B$ avaliadas nas regiões de abrangência do estudo.

Tabela 1: Resumo das principais características observadas entre as 42 propriedades leiteiras avaliadas nas regiões 1 (São Carlos) e 2 (Ribeirão Preto).

\begin{tabular}{ccc}
\hline Característica & Região 1 & Região 2 \\
\hline Condições satisfatórias de ordenha & $33,3 \%$ & $19,1 \%$ \\
Condições regulares de ordenha & $19,1 \%$ & $33,3 \%$ \\
Condições ruins de ordenha & $47,6 \%$ & $47,6 \%$ \\
Uso de tanque de expansão & $90,5 \%$ & $100 \%$ \\
Tipo de sistema de ordenha & $57 \%$ canalizada e & $67 \%$ canalizada e \\
Média de produção de leite & $43 \%$ balde ao bé & $33 \%$ balde ao dé \\
$\mathrm{N}^{\circ}$ médio de animais em lactação & Aprox. 1.000 L/dia & Aprox. 1.000 L/dia \\
$\mathrm{N}^{\circ}$ de animais com mastite clínica & 64 animais & 62 animais \\
CCS média do leite de mistura & 38 animais & 44 animais \\
\hline
\end{tabular}

Em relação a Região 1 (São Carlos), de acordo com os critérios elaborados e descritos no item 5.3 do capítulo Material e Métodos, dentre as 21 fazendas visitadas, 7 $(33,3 \%)$ apresentavam condições de ordenha satisfatórias, 10 (47,6\%) apresentavam condições ruins e as 11 restantes $(19,1 \%)$, condições regulares de ordenha. Já na região 2 (Ribeirão Preto) das 21 propriedades avaliadas, somente 4 (19,1\%) apresentavam condições satisfatórias durante os processos de obtenção do leite na ordenha, 10 (47,6\%) apresentavam condições ruins e as restantes $(33,3 \%)$, condições regulares.

Nota-se que nas duas regiões foi encontrado o mesmo número de fazendas apresentando condições ruins durante a ordenha. Entretanto, na Região 1, um número maior de propriedades apresentou condições de ordenha consideradas satisfatórias, indicando melhores níveis de produção leiteira nesta região.

Observou-se que 19 propriedades leiteiras $(90,5 \%)$ localizadas na região 1 , independentemente do volume de leite produzido, utilizavam tanque de expansão para 
resfriamento do leite e apenas duas ainda persistiam no uso de tanque de imersão com água gelada. Enquanto que na região 2, todas as propriedades já possuíam sistema de resfriamento através de tanque de expansão.

A refrigeração do leite imediatamente após a ordenha na propriedade não elimina os microorganismos já presentes no leite, apenas diminui sua velocidade de multiplicação. Por isso, quanto mais rápido for reduzida à temperatura, melhor será a conservação do leite. Os refrigeradores de expansão oferecem melhores condições para um resfriamento acelerado, além de conservar a temperatura a $4^{\circ} \mathrm{C}$ quando comparados ao sistema de resfriamento por imersão.

Na região 1 quanto ao sistema de ordenha utilizado para a obtenção do leite, 12 propriedades leiteiras $(57 \%)$ utilizavam sistema canalizado com circuito fechado em sala de ordenha com fosso, enquanto que 9 (43\%) utilizavam sistema balde ao pé em estabulação coberta com cochos, Na região 2 predominou o uso do sistema de ordenha canalizado $(67 \%)$.

As Figuras 11 e 12 ilustram os dois sistemas de ordenha (sistema balde ao pé e canalizado, respectivamente) encontrados nas propriedades leiteiras avaliadas no presente estudo.

Em relação a CCS do leite de mistura da região 1, o menor valor encontrado foi de 80.000 céls $/ \mathrm{mL}$ e o maior foi 1.240 .000 céls $/ \mathrm{mL}$ de leite, sendo a média de CCS no leite de mistura de 558.524 céls $/ \mathrm{mL}$. Para a região 2 o menor valor encontrado de CCS do leite de mistura na região 2 foi 68.000 céls/ $\mathrm{mL}$ e o maior foi 1.821 .000 céls/ mL, sendo a média de 806.238 céls/ mL.

Observou-se que a Região 2 apresentou CCS média superior à Região 1, possivelmente devido ao maior número de propriedades apresentando condições ruins de higiene nos processos de obtenção do leite, o que conseqüentemente pode causar um aumento na disseminação de agentes causadores de mastite, elevando a CCS do leite de mistura. Outro fator relacionado às condições de higiene e células somáticas, diz respeito ao número de animais que apresentavam mastite clínica no dia da avaliação em cada propriedade, onde na região 2 foi superior (44 animais/311) ao número de animais com mastite clínica na região 1 (38 animais/307).

Nas Tabelas 2 e 3 estão dispostas mais detalhadamente às características de cada propriedade avaliada no estudo. A Tabela 2 destaca as características da Região 1 (São Carlos) e a Tabela 3 as características das propriedades avaliadas na Região 2 (Ribeirão Preto). 


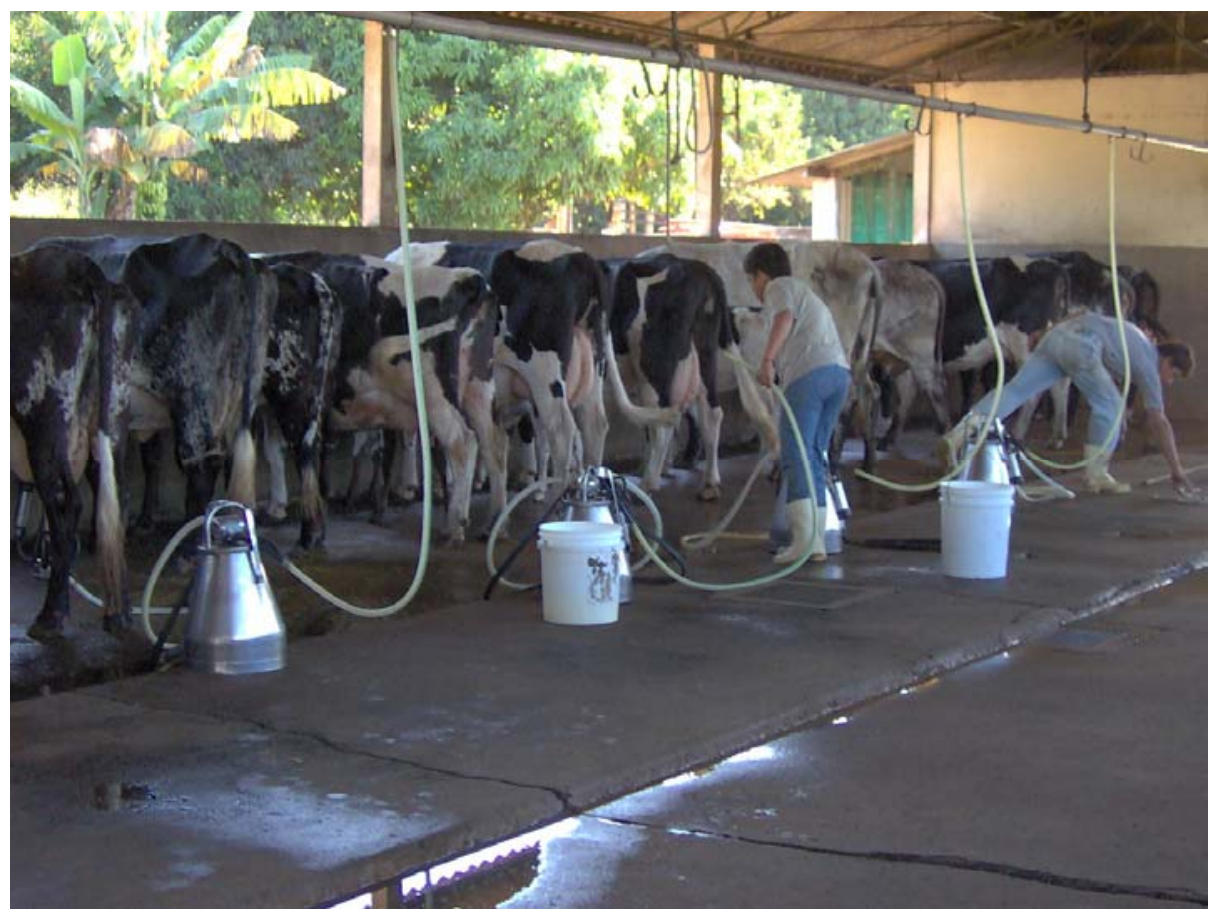

FIGURA 11: Sistema de ordenha tipo balde ao pé, utilizado principalmente em propriedade leiteira de pequeno e médio porte.

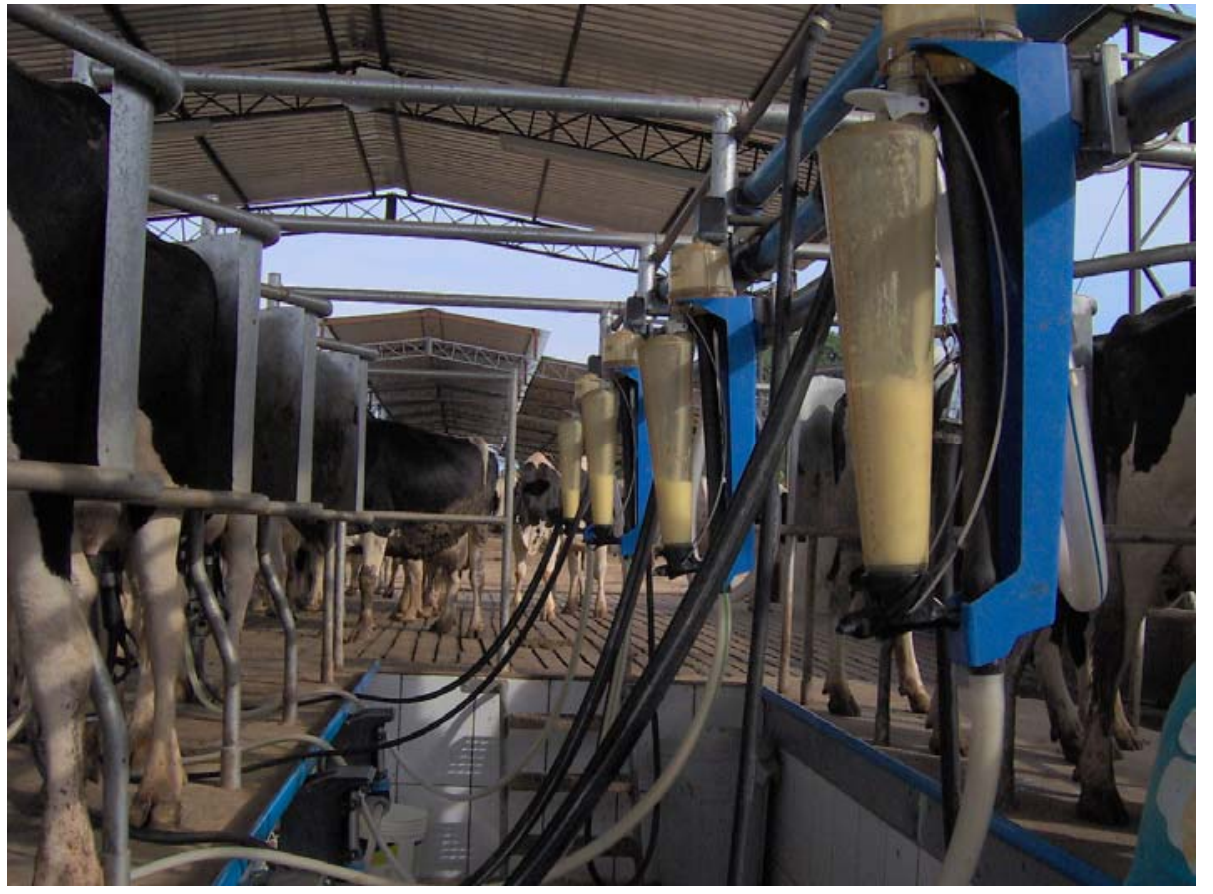

FIGURA 12: Sistema de ordenha tipo canalizada em sistema fechado, utilizado geralmente em propriedades leiteiras de grande porte. 
Tabela 2: Características gerais das propriedades leiteiras avaliadas na Região de São Carlos, São Paulo.

\begin{tabular}{|c|c|c|c|c|c|c|c|c|c|c|c|}
\hline \multirow[b]{2}{*}{ Características } & \multicolumn{11}{|c|}{ Propriedades Leiteiras - Região 1} \\
\hline & 1 & 2 & 3 & 4 & 5 & 6 & 7 & 8 & 9 & 10 & 11 \\
\hline $\mathrm{N}^{\circ}$ animais do rebanho & 60 & 623 & 150 & 690 & 330 & 50 & 300 & 60 & 85 & 170 & 135 \\
\hline $\begin{array}{l}\mathrm{N}^{\circ} \text { animais em } \\
\text { lactação }\end{array}$ & 18 & 98 & 60 & 300 & 156 & 10 & 100 & 25 & 25 & 60 & 60 \\
\hline Produção total/dia (L) & 300 & 1.450 & 850 & 7.000 & 2.700 & 200 & 2.200 & 600 & 300 & 350 & 950 \\
\hline $\begin{array}{l}\mathrm{N}^{0} \text { animais com } \\
\text { mastite clínica }\end{array}$ & 0 & 4 & 1 & 10 & 4 & 5 & 0 & 0 & 2 & 1 & 0 \\
\hline $\begin{array}{l}\text { Faz teste mastite } \\
\text { clínica }\end{array}$ & Não & Sim & Sim & Sim & Sim & Não & Sim & Não & Sim & Sim & Não \\
\hline Faz teste CMT & Sim & Não & Sim & Sim & Não & Não & Sim & Não & Sim & Não & Não \\
\hline Tipo de ordenha & Balde ao pé & Canalizada & Canalizada & Canalizada & Canalizada & Balde ao pé & Canalizada & Balde ao pé & Balde ao pé & Balde ao pé & Balde ao pé \\
\hline Condições de higiene & Ruim & Satisfatória & Satisfatória & Satisfatória & Satisfatória & Ruim & Satisfatória & Ruim & Ruim & Ruim & Ruim \\
\hline Pré dipping & Sim & Sim & Sim & Sim & Não & Não & Sim & Não & Sim & Não & Sim \\
\hline Pós dipping & Não & Sim & Sim & Sim & Sim & Não & Sim & Não & Não & Sim & Não \\
\hline $\begin{array}{l}\text { Desinfecção teteiras } \\
\text { entre ordenhas }\end{array}$ & Não & Sim & Não & Não & Não & Sim & Não & Não & Não & Sim & Sim \\
\hline Resfriamento do leite & Sim & Sim & Sim & Sim & Sim & Sim & Sim & Sim & Sim & Sim & Sim \\
\hline Tipo de resfriador & Expansão & Expansão & Expansão & Expansão & Expansão & Expansão & Expansão & Expansão & Expansão & Expansão & Expansão \\
\hline $\mathrm{N}^{\circ}$ animais avaliados & 9 & 14 & 15 & 20 & 20 & 2 & 20 & 8 & 16 & 20 & 17 \\
\hline$\frac{\text { CCS média do tanque }}{\mathrm{N}^{\circ} \text { animais do rebanho: }}$ & $\frac{384.000}{\text { numero total de }}$ & $\frac{563.000}{\text { e animais inclu }}$ & $\frac{936.000}{\text { luindo bezerra }}$ & $\frac{911.000}{\text { s e novilhas; } \Lambda}$ & $\frac{725.000}{J^{\circ} \text { de animais }}$ & $\frac{80.000}{\text { em lactação: }}$ & $\frac{498.000}{\text { vacas leiteira }}$ & $\frac{225.000}{\text { s em produçãc }}$ & $\frac{672.000}{\text {;; Produção to }}$ & $\frac{1.240 .000}{\mathrm{a} / \mathrm{dia}(\mathrm{L}) \text { : volu }}$ & $\frac{752.000}{\text { me de leite }(\mathrm{L})}$ \\
\hline
\end{tabular}


Tabela 2: Características gerais das propriedades leiteiras avaliadas na Região de São Carlos, São Paulo (continuação).

\begin{tabular}{|c|c|c|c|c|c|c|c|c|c|c|}
\hline \multirow[b]{2}{*}{ Características } & \multicolumn{10}{|c|}{ Propriedades Leiteiras - Região 1} \\
\hline & 12 & 13 & 14 & 15 & 16 & 17 & 18 & 19 & 20 & 21 \\
\hline $\mathrm{N}^{\circ}$ animais do rebanho & 253 & 45 & 39 & 76 & 121 & 166 & 250 & 150 & 32 & 240 \\
\hline$N^{\circ}$ animais em lactação & 90 & 2 & 15 & 13 & 41 & 53 & 60 & 50 & 12 & 100 \\
\hline Produção total/dia (L) & 1.200 & 320 & 230 & 150 & 850 & 1.100 & 1.200 & 900 & 150 & 2.000 \\
\hline $\begin{array}{l}N^{\circ} \text { animais com mastite } \\
\text { clínica }\end{array}$ & 2 & 0 & 0 & 0 & 0 & 1 & 3 & 2 & 0 & 3 \\
\hline Faz teste mastite clínica & Sim & Sim & Não & Não & Sim & Sim & Sim & Sim & Sim & Não \\
\hline Faz teste CMT & Não & Não & Não & Não & Sim & Sim & Não & Sim & Sim & Não \\
\hline Tipo de ordenha & Canalizada & Balde ao pé & Balde ao pé & Balde ao pé & Canalizada & Canalizada & Canalizada & Canalizada & Canalizada & Canalizada \\
\hline Condições de higiene & Regular & Ruim & Ruim & Ruim & Satisfatória & Satisfatória & Ruim & Regular & Regular & Regular \\
\hline Pré dipping & Sim & Não & Não & Não & Sim & Sim & Não & Sim & Sim & Não \\
\hline Pós dipping & Sim & Não & Não & Não & Sim & Sim & Não & Sim & Sim & Sim \\
\hline $\begin{array}{l}\text { Desinfecção teteiras } \\
\text { entre ordenhas }\end{array}$ & Não & Não & Não & Não & Não & Não & Sim & Não & Não & Não \\
\hline Resfriamento do leite & Sim & Sim & Sim & Sim & Sim & Sim & Sim & Sim & Sim & Sim \\
\hline Tipo de resfriador & Expansão & Expansão & Imersão & Imersão & Expansão & Expansão & Expansão & Expansão & Expansão & Expansão \\
\hline $\mathrm{N}^{\circ}$ animais avaliados & 14 & 11 & 11 & 9 & 16 & 18 & 20 & 20 & 9 & 19 \\
\hline $\begin{array}{l}\text { CCS média do tanque } \\
N^{\circ} \text { animais do rebanho: }\end{array}$ & $\frac{698.000}{\text { umero total de }}$ & $\frac{507.000}{\text { animais incluind }}$ & $\frac{355.000}{\text { bezerras e } \mathrm{n}}$ & $\frac{593.000}{\text { ovilhas: } \mathrm{N}^{\circ} \mathrm{de}}$ & $\frac{397.000}{\text { nnimais em la }}$ & $\frac{166.000}{\text { cão: vacas }}$ & $\frac{790.000}{\text { iras em pro }}$ & $\frac{307.000}{\text { ão: Producã }}$ & $\frac{331.000}{\text { otal/dia (L). vc }}$ & $\frac{599.000}{\text { lume de leite }}$ \\
\hline
\end{tabular}


Tabela 3: Características gerais das propriedades leiteiras avaliadas na Região de Ribeirão Preto, São Paulo.

\begin{tabular}{|c|c|c|c|c|c|c|c|c|c|c|c|}
\hline \multirow[b]{2}{*}{ Características } & \multicolumn{11}{|c|}{ Propriedades Leiteiras - Região 2} \\
\hline & 22 & 23 & 24 & 25 & 26 & 27 & 28 & 29 & 30 & 31 & 32 \\
\hline$N^{\circ}$ animais do rebanho & 170 & 140 & 300 & 300 & 420 & 280 & 147 & 40 & 21 & 178 & 370 \\
\hline$N^{\circ}$ animais em lactação & 70 & 70 & 136 & 59 & 173 & 85 & 49 & 14 & 9 & 71 & 130 \\
\hline Produção total/dia (L) & 500 & 1.300 & 3.100 & 2.863 & 3.800 & 1.300 & 1.100 & 150 & 100 & 1.400 & 2.700 \\
\hline $\begin{array}{l}N^{\circ} \text { animais com mastite } \\
\text { clínica }\end{array}$ & 2 & 2 & 3 & 0 & 1 & 1 & 1 & 1 & 0 & 10 & 3 \\
\hline Faz teste mastite clínica & Não & Sim & Sim & Sim & Sim & Sim & Sim & Sim & Sim & Não & Sim \\
\hline Faz teste CMT & Não & Não & Não & $\operatorname{Sim}$ & Sim & Não & Sim & Não & Não & Sim & Sim \\
\hline Tipo de ordenha & Canalizada & Canalizada & Canalizada & Canalizada & Canalizada & Canalizada & Canalizada & Balde ao pé & Balde ao pé & Canalizada & Canalizada \\
\hline Condições de higiene & Regular & Satisfatória & Satisfatória & Satisfatória & Regular & Ruim & Regular & Regular & Regular & Regular & Regular \\
\hline Pré dipping & Não & Sim & Sim & Sim & Não & Não & Sim & Sim & Sim & Sim & Sim \\
\hline Pós dipping & Sim & Sim & Sim & Sim & Sim & Não & Sim & Sim & Sim & Sim & Sim \\
\hline $\begin{array}{l}\text { Desinfecção teteiras } \\
\text { entre ordenhas }\end{array}$ & Não & Não & Sim & Sim & Não & Não & Não & Não & Não & Não & Sim \\
\hline Resfriamento do leite & $\operatorname{Sim}$ & $\operatorname{Sim}$ & $\operatorname{Sim}$ & $\operatorname{Sim}$ & $\operatorname{Sim}$ & $\operatorname{Sim}$ & Sim & $\operatorname{Sim}$ & $\operatorname{Sim}$ & Sim & $\operatorname{Sim}$ \\
\hline Tipo de resfriador & Expansão & Expansão & Expansão & Expansão & Expansão & Expansão & Expansão & Expansão & Expansão & Expansão & Expansão \\
\hline $\mathrm{N}^{\circ}$ animais avaliados & 18 & 20 & 20 & 20 & 20 & 20 & 12 & 3 & 5 & 20 & 20 \\
\hline CCS média do tanque & 309.000 & 1.002 .000 & 383.000 & 322.000 & 1.004 .000 & 1.152 .000 & 493.000 & 789.000 & 68.000 & 1.662 .000 & 307.000 \\
\hline
\end{tabular}

$\mathrm{N}^{\circ}$ animais do rebanho: numero total de animais incluindo bezerras e novilhas; $\mathrm{N}^{\circ}$ de animais em lactação: vacas leiteiras em produção; Produção total/dia (L): volume de leite

(L) medido no dia da avaliação; $\mathrm{N}^{\circ}$ animais com mastite clínica: numero de vacas com presença de grumos no leite no momento do teste da caneca de fundo preto indicando mastite clinica; Faz teste mastite clínica: uso pela propriedade do teste da caneca do fundo preto como rotina na ordenha; Faz teste CMT: uso pela propriedade do Califórnia mastitis test para diagnostico de mastite subclinica no rebanho; Pré dipping: limpeza dos tetos através da imersão com desinfetante antes da ordenha; Pós dipping: imersão dos tetos com desinfetante após a ordenha; Desinfecção teteiras entre ordenhas: procedimento para higienização das teteiras entre um animal e outro durante a ordenha; CCS média do tanque: contagem de células somáticas do leite de mistura (céls/mL). 
Tabela 3: Características gerais das propriedades leiteiras avaliadas na Região de Ribeirão Preto, São Paulo (continuação).

\begin{tabular}{|c|c|c|c|c|c|c|c|c|c|c|}
\hline \multirow[b]{2}{*}{ Características } & \multicolumn{10}{|c|}{ Propriedades Leiteiras - Região 2} \\
\hline & 33 & 34 & 35 & 36 & 37 & 38 & 39 & 40 & 41 & 42 \\
\hline$N^{\circ}$ animais do rebanho & 110 & 41 & 400 & 120 & 70 & 88 & 44 & 85 & 80 & 65 \\
\hline Produção total/dia (L) & 600 & 320 & 2.500 & 850 & 360 & 900 & 350 & 250 & 200 & 150 \\
\hline $\begin{array}{l}N^{\circ} \text { animais com mastite } \\
\text { clínica }\end{array}$ & 1 & 1 & 12 & 1 & 1 & 0 & 2 & 0 & 1 & 1 \\
\hline Tipo de ordenha & Canalizada & Canalizada & Canalizada & Balde ao pé & Canalizada & Canalizada & Balde ao pé & Balde ao pé & Balde ao pé & Balde ao pé \\
\hline Condições de higiene & Ruim & Ruim & Ruim & Ruim & Ruim & Satisfatória & Ruim & Ruim & Ruim & Ruim \\
\hline Pré dipping & $\operatorname{Sim}$ & Não & $\operatorname{Sim}$ & Não & $\operatorname{Sim}$ & Não & $\operatorname{Sim}$ & $\operatorname{Sim}$ & Não & $\operatorname{Sim}$ \\
\hline Pós dipping & Sim & Não & Sim & Não & Não & Sim & Sim & Não & Não & Sim \\
\hline $\begin{array}{l}\text { Desinfecção teteiras entre } \\
\text { ordenhas }\end{array}$ & Não & Não & Não & Não & Não & Sim & Não & Não & Não & Não \\
\hline CCS média do tanque & 604.000 & 1.699 .000 & 914.000 & 1.742 .000 & 1.821 .000 & 951.000 & 721.000 & 180.000 & 293.000 & 515.000 \\
\hline
\end{tabular}

$\mathrm{N}^{\circ}$ animais do rebanho: numero total de animais incluindo bezerras e novilhas; $\mathrm{N}^{\circ}$ de animais em lactação: vacas leiteiras em produção; Produção total/dia (L): volume de leite

(L) medido no dia da avaliação; $\mathrm{N}^{\circ}$ animais com mastite clínica: numero de vacas com presença de grumos no leite no momento do teste da caneca de fundo preto indicando mastite clinica; Faz teste mastite clínica: uso pela propriedade do teste da caneca do fundo preto como rotina na ordenha; Faz teste CMT: uso pela propriedade do Califórnia mastitis test para diagnostico de mastite subclinica no rebanho; Pré dipping: limpeza dos tetos através da imersão com desinfetante antes da ordenha; Pós dipping: imersão dos tetos com desinfetante após a ordenha; Desinfecção teteiras entre ordenhas: procedimento para higienização das teteiras entre um animal e outro durante a ordenha; CCS média do tanque: contagem de células somáticas do leite de mistura (céls $/ \mathrm{mL}$ ). 
Com o objetivo de avaliar a qualidade do leite produzido nas propriedades leiteiras avaliadas neste estudo, foram avaliados os parâmetros de qualidade determinados pela IN 51 (BRASIL, 2002) para leite "in natura" tipo B. Os resultados encontrados em ambas as regiões avaliadas quanto à distribuição das contagens de aeróbios mesófilos e psicrotróficos estão dispostos nas Tabelas 4 e 5 , respectivamente.

Tabela 4: Distribuição das propriedades leiteiras avaliadas nas regiões 1 (São Carlos) e 2 (Ribeirão Preto) de acordo com a contagem de mesófilos no leite de mistura, através do uso de Petrifilm ${ }^{\circledR}$.

\begin{tabular}{ccccccc}
\hline Mesófilos & \multicolumn{2}{c}{ Região 1 } & \multicolumn{2}{c}{ Região 2 } & \multicolumn{2}{c}{ Total } \\
\hline UFC/mL & $\mathbf{N}$ & $\%$ & $\mathbf{N}$ & $\%$ & $\mathbf{N}$ & $\%$ \\
\hline$<10^{4}$ & 2 & 9,5 & 0 & 0,0 & 2 & 4,8 \\
$10^{4}-10^{5}$ & 3 & 14,3 & 2 & 9,5 & 5 & 11,9 \\
$10^{5}-10^{6}$ & 4 & 19,0 & 5 & 23,8 & 9 & 21,4 \\
$10^{6}-10^{7}$ & 10 & 47,6 & 10 & 47,6 & 20 & 47,6 \\
$>10^{7}$ & 2 & 9,5 & 4 & 19,0 & 6 & 14,3 \\
\hline Total & $\mathbf{2 1}$ & $\mathbf{1 0 0 , 0}$ & $\mathbf{2 1}$ & $\mathbf{1 0 0 , 0}$ & $\mathbf{4 2}$ & $\mathbf{1 0 0 , 0}$
\end{tabular}

UFC/mL: unidades formadoras de colônias por mililitros; N: número de propriedades leiteiras; \%: porcentagem.

Tabela 5: Distribuição das propriedades leiteiras avaliadas nas regiões 1 (São Carlos) e 2 (Ribeirão Preto) de acordo com a contagem de psicrotróficos no leite de mistura determinado, através do uso de Petrifilm®.

\begin{tabular}{ccccccc}
\hline Psicrotróficos & \multicolumn{2}{c}{ Região 1 } & \multicolumn{2}{c}{ Região 2 } & \multicolumn{2}{c}{ Total } \\
\hline UFC/mL & $\mathbf{N}$ & $\mathbf{\%}$ & $\mathbf{N}$ & $\mathbf{\%}$ & $\mathbf{N}$ & $\mathbf{\%}$ \\
\hline$<10^{4}$ & 13 & 61,9 & 13 & 61,9 & 26 & 61,9 \\
$10^{4}-10^{5}$ & 5 & 23,8 & 3 & 14,3 & 8 & 19,0 \\
$10^{5}-10^{6}$ & 0 & 0,0 & 1 & 4,7 & 1 & 2,4 \\
$10^{6}-10^{7}$ & 3 & 14,3 & 3 & 14,4 & 6 & 14,3 \\
$>10^{7}$ & 0 & 0,0 & 1 & 4,7 & 1 & 2,4 \\
\hline Total & $\mathbf{2 1}$ & $\mathbf{1 0 0 , 0}$ & $\mathbf{2 1}$ & $\mathbf{1 0 0 , 0}$ & $\mathbf{4 2}$ & $\mathbf{1 0 0 , 0}$ \\
\hline
\end{tabular}

UFC/mL: unidades formadoras de colônias por mililitros; N: número de propriedades leiteiras; \%: porcentagem;

Considerando o limite de $10^{5} \mathrm{UFC/} \mathrm{mL}$ determinado pela IN 51 para aeróbios mesófilos em leite tipo B (BRASIL, 2002), 83,3\% das amostras de leite de mistura analisadas no presente estudo apresentaram-se em desacordo com a legislação. Altas 
contagens de aeróbios mesófilos no leite de mistura indicam falhas nos procedimentos de higiene de ordenha e limpeza dos equipamentos. Portanto, a adequação e fiscalização dos procedimentos higiênico sanitários relacionados a rotina de ordenha dos animais deve ser um foco importante para o controle da qualidade do leite entre os produtores.

Nero et al. (2005) avaliando quatro áreas de quatro grandes estados produtores de leite no Brasil, concluiu que algumas áreas enfrentam dificuldades de adequação às normas estabelecidas pela IN 51 para a produção de leite cru refrigerado. Segundo os autores os resultados obtidos mostraram uma alta freqüência de amostras de leite de mistura $(48,57 \%)$ com elevados níveis de contaminação por aeróbios mesófilos.

Quanto à contagem de psicrotróficos, a IN 51 não determina um limite específico, porém altas contagens indicam conservação térmica inadequada do leite na propriedade após a sua obtenção. Somente para efeito de comparação, considerou-se o valor máximo determinado para aeróbios mesófilos $\left(10^{5} \mathrm{UFC} / \mathrm{mL}\right)$ pela legislação vigente. E, constatou-se que aproximadamente $80 \%$ das propriedades das duas regiões avaliadas apresentaram valores menores que $10^{5} \mathrm{UFC} / \mathrm{mL}$ para psicrotróficos.

A contaminação do leite por bactérias psicrotróficas é considerada, de acordo com Santos e Fonseca (2002) como um fator crítico, que influencia na manutenção da qualidade do leite refrigerado. Estes microrganismos estão amplamente distribuídos no ambiente, podendo ser encontrados na água, solo e animais. De acordo com Desmasures et al. (1997) as principais fontes de psicrotróficos no leite durante sua obtenção são a superfície dos tetos e o equipamento de ordenha.

De acordo com a IN 51, o leite deverá ser refrigerado e atingir a temperatura de $4^{\circ} \mathrm{C}$ (tanques de expansão) ou $7^{\circ} \mathrm{C}$ (tanques de imersão), num período não superior a 3 horas após o término da ordenha. Na recepção dos laticínios, o leite desses tanques não deverá apresentar temperatura superior a $7^{\circ} \mathrm{C}$ para leite $\mathrm{B}$.

A CCS no leite de mistura é uma ferramenta importante para se avaliar o nível de mastite subclínica no rebanho, estimar as perdas quantitativas e qualitativas de produção do leite na propriedade e posteriormente de seus derivados, indicar a qualidade do leite produzido e estabelecer medidas de prevenção e controle da mastite.

$\mathrm{Na}$ Tabela 6 estão dispostos os resultados quanto a distribuição da CCS do leite de mistura das 42 propriedades leiteiras avaliadas. A IN 51 determina valores menores que 600.000 céls/ $\mathrm{mL}$ para o leite tipo B. Das 42 propriedades, $21,4 \%$ apresentaram valores acima de 1.000 .000 céls/ $\mathrm{mL}$ indicando sérios problemas de mastite entre os animais em produção. A maioria das propriedades, 30,9\% apresentou valores entre 200 e 500.000 céls/ $\mathrm{mL}$, que é considerado adequado para leite tipo $\mathrm{B}$. 
Esperavam-se valores mais elevados entre os resultados de CCS do leite de mistura das propriedades leiteiras avaliadas, visto que a mastite, inflamação da glândula mamária e considerada a principal enfermidade entre os bovinos leiteiros, é a principal responsável pela elevação da CCS do leite dos animais, bem como do leite de mistura.

O aumento da CCS é resultante da transferência de células inflamatórias do sangue, principalmente leucócitos, para o leite. Estas alterações no leite significam redução na sua qualidade inicial e conseqüentemente na qualidade dos seus derivados (SMITH et al. 2001).

No entanto, verificou-se que as mastites e, por conseguinte as células somáticas não se caracterizaram como o principal fator determinante para diminuir a qualidade do leite neste estudo. Entretanto, a contagem de bactérias mesófilas, parâmetro que indica boas condições de higiene antes, durante e após os processos de obtenção do leite, apresentou valores muito elevados, indicando que este parâmetro pode ser um obstáculo na adequação das propriedades leiteiras a IN 51 e aos avanços na melhoria da qualidade do leite no país.

Tabela 6: Distribuição das propriedades leiteiras avaliadas nas regiões 1 (São Carlos) e 2 (Ribeirão Preto) de acordo com a contagem de células somáticas (CCS) no leite de mistura, realizado através da técnica de citometria de fluxo.

\begin{tabular}{ccccccc}
\hline CCS & \multicolumn{2}{c}{ Região 1 } & \multicolumn{2}{c}{ Região 2 } & \multicolumn{2}{c}{ Total } \\
\hline Céls $/ \mathbf{m L}\left(\mathbf{\times 1 \mathbf { 1 0 } ^ { \mathbf { 3 } } )}\right.$ & $\mathbf{N}$ & $\mathbf{\%}$ & $\mathbf{N}$ & $\mathbf{\%}$ & $\mathbf{N}$ & $\mathbf{\%}$ \\
\hline$<200$ & 2 & 9,5 & 2 & 9,5 & 4 & 9,5 \\
$200-500$ & 7 & 33,3 & 6 & 28,6 & 13 & 30,9 \\
$500-700$ & 5 & 23,8 & 2 & 9,5 & 7 & 16,6 \\
$700-1.000$ & 5 & 23,8 & 4 & 19,0 & 9 & 21,4 \\
$>1.000$ & 2 & 9,5 & 7 & 33,3 & 9 & 21,4 \\
\hline Total & $\mathbf{2 1}$ & $\mathbf{1 0 0 , 0}$ & $\mathbf{2 1}$ & $\mathbf{1 0 0 , 0}$ & $\mathbf{4 2}$ & $\mathbf{1 0 0 , 0}$
\end{tabular}

céls/mL: células por mililitro de leite; $\mathrm{N}$ : número de propriedades leiteiras; \%: porcentagem;

5.3. Isolamento e identificação de Staphylococcus aureus

5.3.1 Amostras de leite individuais (vacas leiteiras em produção)

O número de animais amostrados e o número de animais positivos para Staphylococcus aureus em cada propriedade de acordo com a região de localização encontram-se na Tabela 7. 
Tabela 7: Número de animais amostrados por região e por fazenda e o número de animais positivos encontrado em cada fazenda para Staphylococcus aureus.

\begin{tabular}{|c|c|c|c|c|c|c|c|}
\hline \multicolumn{4}{|c|}{ Região 1} & \multicolumn{4}{|c|}{ Região 2} \\
\hline Fazenda & $\begin{array}{c}N \text { animais } \\
\text { amostrados }\end{array}$ & $\begin{array}{c}\text { S. } \\
\text { aureus + }\end{array}$ & $\%$ & Fazenda & $\begin{array}{c}N \text { animais } \\
\text { amostrados }\end{array}$ & $\begin{array}{c}\text { S. } \\
\text { aureus + }\end{array}$ & $\%$ \\
\hline 1 & 9 & 0 & 0,0 & 22 & 13 & 2 & 15,4 \\
\hline 2 & 14 & 1 & 7,1 & 23 & 20 & 2 & 10,0 \\
\hline 3 & 15 & 2 & 13,3 & 24 & 20 & 0 & 0,0 \\
\hline 4 & 20 & 0 & 0,0 & 25 & 20 & 2 & 10,0 \\
\hline 5 & 20 & 1 & 5,0 & 26 & 20 & 2 & 10,0 \\
\hline 6 & 2 & 0 & 0,0 & 27 & 20 & 0 & 0,0 \\
\hline 7 & 20 & 0 & 0,0 & 28 & 12 & 0 & 0,0 \\
\hline 8 & 8 & 4 & 50,0 & 29 & 3 & 0 & 0,0 \\
\hline 9 & 16 & 0 & 0,0 & 30 & 5 & 0 & 0,0 \\
\hline 10 & 20 & 0 & 0,0 & 31 & 20 & 0 & 0,0 \\
\hline 11 & 17 & 0 & 0,0 & 32 & 20 & 0 & 0,0 \\
\hline 12 & 14 & 0 & 0,0 & 33 & 15 & 5 & 33,3 \\
\hline 13 & 11 & 0 & 0,0 & 34 & 10 & 0 & 0,0 \\
\hline 14 & 11 & 1 & 9,0 & 35 & 20 & 0 & 0,0 \\
\hline 15 & 9 & 0 & 0,0 & 36 & 15 & 1 & 6,6 \\
\hline 16 & 16 & 0 & 0,0 & 37 & 18 & 2 & 11,1 \\
\hline 17 & 18 & 0 & 0,0 & 38 & 15 & 3 & 20,0 \\
\hline 18 & 19 & 0 & 0,0 & 39 & 12 & 0 & 0,0 \\
\hline 19 & 20 & 1 & 5,0 & 40 & 11 & 0 & 0,0 \\
\hline 20 & 9 & 0 & 0,0 & 41 & 12 & 2 & 16,6 \\
\hline 21 & 19 & 0 & 0,0 & 42 & 10 & 2 & 20,0 \\
\hline Total & 307 & 12 & 3,9 & Total & 311 & 21 & 6,7 \\
\hline
\end{tabular}

Não foram observadas diferenças estatísticas significativas, pelo teste "Z" a 5\%, nos percentuais totais indicados na última linha.

$\mathrm{Na}$ região 1 (São Carlos) foram coletadas amostras de leite de 307 animais, totalizando 21 propriedades leiteiras e, destes animais, 12 apresentaram-se positivos para S. aureus (3,9\%). Na região 2 (Ribeirão Preto) foram avaliados 311 animais, sendo que 21 $(6,7 \%)$ animais foram positivos. De acordo com Sá et al. (2004) as taxas de isolamento podem variar de $9,1 \%$ a $85 \%$, embora se devam considerar as diferenças locais dentro de uma mesma região ou estado, diferenças de metodologia de coleta e armazenamento de amostras e de análises laboratoriais. 
Um aspecto a ser considerado em relação à taxa de isolamento de $S$. aureus nas amostras de leite, é que muitas vezes esta bactéria tem padrão intermitente de eliminação, além do fato de encontrar-se geralmente dentro de células, sobretudo leucócitos e neutrófilos, o que dificulta o seu isolamento (RISTOW e PEREZ JUNIOR, 2006).

Godden et al. (2002) avaliaram o efeito do momento (antes ou depois da ordenha) e forma (refrigerada ou congelada) de colheita das amostras de leite de vacas com mastite para detectar a presença de $S$. aureus. Os autores afirmaram que a probabilidade de detectar este agente através de cultura de uma única amostra composta de leite de vacas com mastite subclínica é de apenas $58 \%$ a $63 \%$.

No presente estudo, utilizaram-se amostras compostas de leite, colhidas após a ordenha completa dos animais. Segundo Godden et al. (2002), a baixa sensibilidade das amostras compostas ocorre devido ao efeito diluição do leite pelos quartos mamários não infectados. A sensibilidade aumenta para $94 \%$ a $99 \%$ se duas ou três amostras consecutivas são coletadas ao longo de um período.

O volume de produção de leite diário de uma propriedade pode indicar o seu tamanho e importância e o grau de tecnologia aplicado na produção. Com o propósito de avaliar a relação entre a ocorrência de $S$. aureus e estas características, as propriedades avaliadas nas duas regiões foram divididas em três grupos de acordo com o volume total de produção de leite diária, sendo: Grupo de produção menor que $400 \mathrm{~L}$ de leite/dia, Grupo de produção entre 400 e $1.000 \mathrm{~L}$ de leite/dia e Grupo de produção maior que $1.000 \mathrm{~L}$ de leite/dia (Tabela 8).

Tabela 8: Número de animais amostrados e positivos para Staphylococcus aureus agrupados de acordo com o volume de produção de leite/dia.

\begin{tabular}{|c|c|c|c|c|c|c|c|c|}
\hline & \multicolumn{2}{|c|}{$<400$ L/dia } & \multicolumn{2}{|c|}{$400-1.000$ L/dia } & \multicolumn{2}{|c|}{$>1.000 \mathrm{~L} / \mathrm{dia}$} & \multicolumn{2}{|c|}{ Total } \\
\hline & $\mathbf{N}$ & $\%$ & $\mathbf{N}$ & $\%$ & $\mathbf{N}$ & $\%$ & $\mathbf{N}$ & $\%$ \\
\hline S. aureus + & 12 & $4,1^{b}$ & 12 & $16,9^{a}$ & 9 & $3,5^{b}$ & 33 & 5,4 \\
\hline S. aureus - & 182 & 95,9 & 87 & 83,1 & 316 & 96,5 & 585 & 94,6 \\
\hline Total & 194 & 100,0 & 99 & 100,0 & 325 & 100,0 & 618 & 100,0 \\
\hline
\end{tabular}

Em uma mesma linha, percentuais com letras sobrescritas diferentes diferem estatisticamente pelo teste " $Z$ " a $5 \%$.

A ocorrência de $S$. aureus foi maior $(16,9 \%)$ nos animais pertencentes às propriedades com produção de leite intermediária (entre 400 a 1.000 L/dia), quando comparada aos dois outros grupos $(p<0,05)$. Deve-se ressaltar a relevância deste fato para a Saúde Pública, ao se considerar o risco de veiculação de $S$. aureus através do leite, uma 
vez que grande parte das propriedades leiteiras do Estado de São Paulo apresenta um volume de produção dentro desta faixa.

Observou-se também que propriedades pequenas (produção $<400 \mathrm{~L} / \mathrm{dia}$ ) e propriedades maiores (produção $>1.000 \mathrm{~L}$ /dia) não diferiram estatisticamente entre si, indicando não haver diferença entre as freqüências de isolamento de $S$. aureus entre elas. Logo, propriedades pequenas e grandes por apresentarem menor volume de leite e melhores condições de produção, respectivamente, não seriam consideradas um risco de veiculação de $S$. aureus através do leite.

Quanto à CCS os animais foram distribuídos em dois grupos para fins de comparação na análise estatística: Grupo de baixa CCS $(<200.000$ céls $/ \mathrm{mL}$ de leite), que representa a ausência de mastite subclínica e Grupo de alta CCS (> 200.000 céls $/ \mathrm{mL}$ de leite), que representa a presença de qualquer grau de mastite subclínica.

O número de animais amostrados positivos em cada grupo está descrito na Tabela 9. Pode-se notar que o número geral de animais avaliados com CCS maior que 200.000 céls $/ \mathrm{mL}$ de leite foi muito superior (458 animais) aos animais com CCS menor que 200.000 céls $/ \mathrm{mL}$ (160 animais), evidenciando claramente a presença de mastite subclínica entre os animais avaliados neste estudo.

Quanto à ocorrência de S. aureus, não houve diferença estatística em relação à presença deste patógeno e a CCS do leite dos animais, o que permite afirmar que o $S$. aureus pode ser isolado tanto de animais sadios como de animais com mastite subclínica, nas condições em que este estudo foi realizado.

Tabela 9: Número de animais amostrados positivos para Staphylococcus aureus de acordo com a contagem de células somáticas (CCS).

\begin{tabular}{ccccccc}
\hline & \multicolumn{2}{c}{$\mathbf{2 0 0 . 0 0 0}$ céls $/ \mathbf{m L}$} & \multicolumn{2}{c}{$>\mathbf{2 0 0 . 0 0 0}$ céls/mL } & \multicolumn{2}{c}{ Total } \\
\hline S. aureus + & $\mathbf{N}$ & $\mathbf{\%}$ & $\mathbf{N}$ & $\mathbf{\%}$ & $\mathbf{N}$ & $\%$ \\
S. aureus - & 9 & 5,6 & 24 & 5,2 & 33 & 5,4 \\
\hline Total & 151 & 94,4 & 434 & 94,8 & 585 & 94,6 \\
\hline
\end{tabular}

Não foram observadas diferenças estatísticas significativas, pelo teste "Z" a 5\%, nos percentuais indicados em uma mesma linha.

A seguir são descritos os resultados quanto ao número de animais amostrados em relação ao sistema de ordenha utilizado na propriedade (canalizado ou balde ao pé) (Tabela 10). Verificou-se uma maior ocorrência de $S$. aureus entre os animais que foram ordenhados em sistema balde ao pé $(7 \%)$, porém não foram observadas diferenças estatísticas entre os grupos avaliados. 
$\mathrm{Na}$ caracterização de propriedades leiteiras em Minas Gerais com base na contaminação bacteriana do leite cru, Guerreiro et al. (2005) verificaram que uma das três propriedades avaliadas com ordenha mecânica apresentou contagem bacteriana inicial do leite de mistura de $3,5 \times 10^{6} \mathrm{UFC} / \mathrm{ml}$, considerado relativamente elevado. Este resultado de contagem bacteriana no leite de mistura foi maior do que o observado na propriedade com ordenha manual rudimentar, indicando que a tecnologia quanto aos sistemas de ordenha utilizados não implica, necessariamente, em um leite com melhor qualidade microbiológica e sim em mais um item a ser considerado como possível agente de contaminação bacteriana.

Diferentemente do que afirmou Guerreiro et al. (2005), o presente estudo indicou que propriedades com sistemas de ordenha mais simples com equipamento balde ao pé, possuem maior risco de veicularem $S$. aureus e apresentarem conseqüentemente maior contaminação inicial do leite cru do que propriedades com sistemas de ordenha canalizados.

Deve-se considerar que o equipamento de ordenha é uma fonte importante de contaminação do leite e os procedimentos de limpeza e higienização, nesse componente, podem influenciar diretamente no índice de contaminação microbiana do leite.

Tabela 10: Número de animais amostrados positivos para Staphylococcus aureus de acordo com o sistema de ordenha utilizado na propriedade.

\begin{tabular}{ccccccc}
\hline & \multicolumn{2}{c}{ Canalizada } & \multicolumn{2}{c}{ Balde ao pé } & \multicolumn{2}{c}{ Total } \\
\hline & $\mathbf{N}$ & $\mathbf{\%}$ & $\mathbf{N}$ & $\mathbf{\%}$ & $\mathbf{N}$ & $\mathbf{\%}$ \\
\hline S. aureus + & 21 & 4,7 & 12 & 7,0 & 33 & 5,4 \\
S. aureus - & 426 & 95,3 & 159 & 93,0 & 585 & 94,6 \\
\hline Total & $\mathbf{4 4 7}$ & $\mathbf{1 0 0 , 0}$ & $\mathbf{1 7 1}$ & $\mathbf{1 0 0 , 0}$ & $\mathbf{6 1 8}$ & $\mathbf{1 0 0 , 0}$
\end{tabular}

Não foram observadas diferenças estatísticas significativas, pelo teste "Z" a 5\%, nos percentuais indicados em uma mesma linha.

Pelo fato do $S$. aureus ser uma bactéria de origem contagiosa e sua disseminação entre os animais dar-se principalmente durante a ordenha, pelas más condições de higiene dos animais, dos ordenhadores e dos procedimentos de ordenha, relacionou-se a presença de $S$. aureus às condições de higiene encontradas nas propriedades.

Relativamente ao diagnóstico e prevenção de mastites, os procedimentos avaliados foram: realização do pré dipping e pós dipping, uso de luvas descartáveis, realização do teste da caneca de fundo preto para detecção de mastite clínica, desinfecção de teteiras com cloro durante a ordenha e o tipo de desinfetante utilizado no pré e/ou no pós dipping. Os dados obtidos estão dispostos nas Tabelas 11 a 16. 
Quanto à ocorrência de S. aureus e as práticas de pré e pós dipping, não foram detectadas diferenças estatísticas (Tabela 11 e 12). Entretanto, verificou-se que o uso do pré dipping em termos absolutos interferiu na ocorrência de S. aureus, em torno de $50 \%$. Já o pós dipping não interferiu na ocorrência de $S$. aureus uma vez que esta prática é realizada após a ordenha dos animais. Estes dois procedimentos são essenciais na rotina de ordenha para que se mantenha um padrão de higiene adequado no momento da obtenção do leite e se previna o aparecimento de mastite entre os animais (TAVERNA, 2004). Os dados obtidos no presente experimento indicam que somente o pré dipping apresenta importância para reduzir a ocorrência de $S$. aureus no leite.

Tabela 11: Número de animais amostrados positivos para Staphylococcus aureus de acordo com a prática de pré dipping.

\begin{tabular}{|c|c|c|c|c|c|c|}
\hline \multicolumn{7}{|c|}{ Pré Dipping } \\
\hline & \multicolumn{2}{|c|}{ Sim } & \multicolumn{2}{|c|}{ Não } & \multicolumn{2}{|c|}{ Total } \\
\hline & $\mathbf{N}$ & $\%$ & $\mathbf{N}$ & $\%$ & $\mathbf{N}$ & $\%$ \\
\hline S. aureus + & 18 & 4,3 & 15 & 7,3 & 33 & 5,4 \\
\hline S. aureus - & 396 & 95,7 & 189 & 92,7 & 585 & 94,6 \\
\hline Total & 414 & 100,0 & 204 & 100,0 & 618 & 100,0 \\
\hline
\end{tabular}

Não foram observadas diferenças estatísticas significativas, pelo teste "Z" a 5\%, nos percentuais totais indicados na última linha.

Tabela 12: Número de animais amostrados positivos para Staphylococcus aureus de acordo com a prática de pós dipping.

\begin{tabular}{ccccccc}
\hline & \multicolumn{3}{c}{ Pós Dipping } & \multicolumn{2}{c}{ Total } \\
\hline & \multicolumn{2}{c}{ Sim } & $\mathbf{N}$ & $\mathbf{N a n o}$ & $\mathbf{N}$ & $\mathbf{\%}$ \\
\hline S. aureus + & 23 & 5,3 & 10 & 5,3 & 33 & 5,4 \\
S. aureus - & 409 & 94,7 & 176 & 94,7 & 585 & 94,6 \\
\hline Total & $\mathbf{4 3 2}$ & $\mathbf{1 0 0 , 0}$ & $\mathbf{1 8 6}$ & $\mathbf{1 0 0 , 0}$ & $\mathbf{6 1 8}$ & $\mathbf{1 0 0 , 0}$ \\
\hline
\end{tabular}

Não foram observadas diferenças estatísticas significativas, pelo teste "Z" a 5\%, nos percentuais totais indicados na última linha.

Em relação ao uso de luvas descartáveis durante a ordenha (Tabela 13), verificou-se uma maior ocorrência de $S$. aureus entre os animais ordenhados sem a utilização de luvas descartáveis $(6,7 \%)$, no entanto, este resultado não foi estatisticamente diferente. As luvas descartáveis quando usadas corretamente, diminuem a contaminação cruzada entre os animais e entre o homem e os animais. 
De acordo com vários autores (BRYAN, 1976; GENIGEORGIS, 1989; MURRAY, 1998; CHAPAVAL, 1999), a fonte mais provável de contaminação primária de alimentos por S. aureus é o próprio ser humano. Uma grande parte da população humana possui $S$. aureus como parte da microbiota do nariz, pescoço e mãos, e, conseqüentemente, essas pessoas que manuseiam alimentos podem contaminar o produto cru, os equipamentos, e/ou o produto final.

Tabela 13: Número de animais amostrados positivos para Staphylococcus aureus de acordo com a prática de uso de luvas descartáveis durante a ordenha.

\begin{tabular}{cccccccc}
\hline & \multicolumn{3}{c}{ Luvas descartáveis } & \multicolumn{2}{c}{ Total } \\
\hline & \multicolumn{2}{c}{ Sim } & $\mathbf{N}$ & $\mathbf{N}$ & $\mathbf{N a ̃ o}$ & $\mathbf{N}$ & $\mathbf{\%}$ \\
\hline S. aureus + & 8 & 3,2 & 25 & 6,7 & 33 & 5,4 \\
S. aureus - & 240 & 96,8 & 345 & 93,3 & 585 & 94,6 \\
\hline Total & $\mathbf{2 4 8}$ & $\mathbf{1 0 0 , 0}$ & $\mathbf{3 7 0}$ & $\mathbf{1 0 0 , 0}$ & $\mathbf{6 1 8}$ & $\mathbf{1 0 0 , 0}$
\end{tabular}

Não foram observadas diferenças estatísticas significativas, pelo teste "Z" a 5\%, nos percentuais indicados em uma mesma linha.

Tondo et al. (2000) examinando a contaminação por S. aureus em leite e derivados e sua relação com os isolados e as fontes de contaminação, verificaram ocorrência de $35,2 \%$ de $S$. aureus nos seres humanos, manipuladores dos alimentos.

$\mathrm{Na}$ Tabela 14 estão dispostos os resultados quanto ao número de animais amostrados e os positivos para $S$. aureus de acordo com a prática de verificação de mastite clínica antes da ordenha (teste da caneca de fundo preto). Observou-se entre as 42 propriedades avaliadas que na maioria dos animais esta prática era adotada como rotina (434 animais/ 618 animais). O teste da caneca de fundo preto se encontra bastante difundida entre os produtores, pois se sabe que o leite contendo grumos não pode ser incorporado ao leite de mistura, por alterar a qualidade do produto.

A Tabela 15 apresenta a ocorrência de S. aureus de acordo com a prática de desinfecção de teteiras com cloro durante a ordenha. Pode-se observar que em animais onde esta prática é realizada, a taxa de isolamento de $S$. aureus foi menor (4\%), embora não tenha sido detectada nenhuma diferença estatística entre os grupos avaliados. 
Tabela 14: Número de animais amostrados positivos para Staphylococcus aureus de acordo com o uso do teste da caneca de fundo preto para detecção de mastite clínica.

Teste da caneca de fundo preto

\begin{tabular}{ccccccc}
\hline & \multicolumn{2}{c}{ Sim } & \multicolumn{2}{c}{ Não } & \multicolumn{2}{c}{ Total } \\
\hline & $\mathbf{N}$ & $\mathbf{N}$ & $\mathbf{N}$ & $\mathbf{0}$ & $\mathbf{N}$ & $\mathbf{\%}$ \\
\hline S. aureus + & 20 & 4,6 & 13 & 7,0 & 33 & 5,4 \\
S. aureus - & 414 & 95,4 & 171 & 93,0 & 585 & 94,6 \\
\hline Total & $\mathbf{4 3 4}$ & $\mathbf{1 0 0 , 0}$ & $\mathbf{1 8 4}$ & $\mathbf{1 0 0 , 0}$ & $\mathbf{6 1 8}$ & $\mathbf{1 0 0 , 0}$ \\
\hline
\end{tabular}

Não foram observadas diferenças estatísticas significativas, pelo teste "Z" a 5\%, nos percentuais indicados em uma mesma linha.

O uso de desinfecção de teteiras durante a ordenha é, de fato, muito questionável entre os pesquisadores e técnicos. Em trabalho realizado por Amaral et al. (2004), a desinfecção das teteiras com hipoclorito de sódio ou dicloroisocianurato de sódio durante a ordenha não foi eficiente como método preventivo de redução da ação das teteiras como veículo de transmissão de microrganismos para o úbere e para o leite. Os autores constataram que a prática de desinfecção de teteiras não reduziu significativamente o número de coliformes e Staphylococcus sp., destacando que em algumas teteiras, após o uso do desinfetante ocorreu aumento no número de microrganismos isolados.

Tabela 15: Número de animais amostrados positivos para Staphylococcus aureus de acordo com a prática de desinfecção de teteiras com cloro.

\begin{tabular}{ccccccc}
\hline & \multicolumn{3}{c}{ Desinfecção de Teteiras } & \multicolumn{2}{c}{ Total } \\
\hline & \multicolumn{2}{c}{ Sim } & $\mathbf{N}$ & Não & $\mathbf{N}$ & $\%$ \\
\hline S. aureus + & 6 & 4,0 & 27 & 5,7 & 33 & 5,4 \\
S. aureus - & 141 & 96,0 & 444 & 94,3 & 585 & 94,6 \\
\hline Total & $\mathbf{1 4 7}$ & $\mathbf{1 0 0 , 0}$ & $\mathbf{4 7 1}$ & $\mathbf{1 0 0 , 0}$ & $\mathbf{6 1 8}$ & $\mathbf{1 0 0 , 0}$ \\
\hline
\end{tabular}

Não foram observadas diferenças estatísticas significativas, pelo teste "Z" a 5\%, nos percentuais indicados em uma mesma linha.

$\mathrm{Na}$ Tabela 16 estão dispostos os animais amostrados positivos para $\mathrm{S}$. aureus de acordo com o tipo de desinfetante utilizado no pré e pós dipping. Verificou-se uma tendência no uso do iodo ao invés de cloro, verificado através do número de animais em que foi usado iodo (438 animais) quando comparado ao número de animais em que foi usado o cloro (65 animais). Este fato é devido provavelmente a maior facilidade de uso do iodo, pois não há a 
necessidade de diluição e pela sua melhor estabilidade em relação à concentração de matéria orgânica (fezes, urina e barro) no ambiente da ordenha.

Tabela 16: Número de animais amostrados positivos para Staphylococcus aureus de acordo com o tipo de desinfetante utilizado no pré e pós dipping.

\begin{tabular}{ccccccccc}
\hline & \multicolumn{1}{c}{ Desinfetantes } \\
\hline & \multicolumn{2}{c}{ lodo } & \multicolumn{2}{c}{ Cloro } & \multicolumn{2}{c}{ Nenhum } & \multicolumn{2}{c}{ Total } \\
\hline & $\mathbf{N}$ & $\mathbf{0}$ & $\mathbf{N}$ & $\mathbf{0}$ & $\mathbf{N}$ & $\%$ & $\mathbf{N}$ & $\%$ \\
\hline S. aureus + & 22 & 5,0 & 3 & 4,6 & 8 & 7,0 & 33 & 5,4 \\
S. aureus - & 416 & 95,0 & 62 & 95,4 & 107 & 93,0 & 585 & 94,6 \\
\hline Total & $\mathbf{4 3 8}$ & $\mathbf{1 0 0 , 0}$ & $\mathbf{6 5}$ & $\mathbf{1 0 0 , 0}$ & $\mathbf{1 1 5}$ & $\mathbf{1 0 0 , 0}$ & $\mathbf{6 1 8}$ & $\mathbf{1 0 0 , 0}$
\end{tabular}

Não foram observadas diferenças estatísticas significativas, pelo teste "Z" a 5\%, nos percentuais indicados em uma mesma linha.

\subsubsection{Amostras de leite de mistura (Tanques de expansão)}

Quanto à localização das propriedades leiteiras avaliadas neste estudo, as amostras de leite de mistura que foram positivas para S. aureus encontram-se na Tabela 17. A freqüência de isolamento de $S$. aureus no leite de mistura foi a mesma nas duas regiões $(19 \%)$. No entanto, quando se compara a freqüência geral de isolamento de $S$. aureus no leite individual dos animais $(5,4 \%)$ percebe-se que no leite de mistura foi aproximadamente três vezes maior, indicando que possivelmente ocorram contaminações por este microrganismo ao longo do trajeto do leite desde a extração da glândula mamária até o tanque de mistura.

As contagens de $S$. aureus em Agar BP nas amostras de leite de mistura variaram de $10^{2}$ a $10^{4} \mathrm{UFC} / \mathrm{mL}$. Tondo et al. (2000) analisando leite cru, verificaram contagens variando desde não detectável até $1,8 \times 10^{4} \mathrm{UFC} / \mathrm{mL}$, com média de $3,5 \times 10^{3}$ UFC/mL. No Brasil, a contagem média de $S$. aureus no leite in natura está em torno de $10^{5}$ UFC/mL (SENA, 2000).

$\mathrm{Na}$ Tabela 18, estão dispostos os resultados referentes as amostras de leite de mistura positivos para $S$. aureus de acordo com o volume de leite produzido em cada propriedade. Não foram detectadas diferenças estatísticas significativas entre os grupos avaliados. Entretanto, em valores absolutos, verificou-se que houve maior ocorrência de $S$. aureus no leite de mistura de propriedades que produziam volumes inferiores a $400 \mathrm{~L}$ leite/dia (29,4\%). Entre as possíveis causas desta maior ocorrência de $S$. aureus, pode-se citar o efeito de concentração devido ao menor volume de leite produzido, menor número de 
animais em ordenha, sistemas de resfriamento pouco eficientes e transporte do leite em condições precárias.

Tabela 17: Número de amostras de leite de mistura, positivos para Staphylococcus aureus, agrupados de acordo com a região (1 - São Carlos e 2 - Ribeirão Preto).

\begin{tabular}{ccccccc}
\hline & \multicolumn{2}{c}{ Região 1 } & \multicolumn{2}{c}{ Região 2 } & \multicolumn{2}{c}{ Total } \\
\hline & $\mathbf{N}$ & $\mathbf{\%}$ & $\mathbf{N}$ & $\mathbf{\%}$ & $\mathbf{N}$ & $\mathbf{\%}$ \\
\hline S. aureus + & 4 & 19,0 & 4 & 19,0 & 8 & 19,0 \\
S. aureus - & 17 & 81,0 & 17 & 81,0 & 34 & 81,0 \\
\hline Total & $\mathbf{2 1}$ & $\mathbf{1 0 0 , 0}$ & $\mathbf{2 1}$ & $\mathbf{1 0 0 , 0}$ & $\mathbf{4 2}$ & $\mathbf{1 0 0 , 0}$
\end{tabular}

Não foram observadas diferenças estatísticas significativas, pelo teste " $Z$ " a $5 \%$, nos percentuais indicados em uma mesma linha.

Tabela 18: Número de amostras de leite de mistura, positivos para Staphylococcus aureus agrupados de acordo com o volume de leite produzido na propriedade.

\begin{tabular}{lcccccccc}
\hline & \multicolumn{2}{c}{$\mathbf{4 0 0}$ L/dia } & \multicolumn{4}{c}{$\mathbf{4 0 0}-\mathbf{1 . 0 0 0}$ L/dia } & \multicolumn{1}{c}{$>\mathbf{1 . 0 0 0}$ L/dia } & \multicolumn{2}{c}{ Total } \\
\hline & $\mathbf{N}$ & $\mathbf{9}$ & $\mathbf{N}$ & $\mathbf{9}$ & $\mathbf{N}$ & $\mathbf{9}$ & $\mathbf{N}$ & $\%$ \\
\hline S. aureus + & 5 & 29,4 & 1 & 12,5 & 2 & 11,8 & 8 & 19,0 \\
S. aureus - & 12 & 70,6 & 7 & 87,5 & 15 & 88,2 & 34 & 81,0 \\
\hline \multicolumn{1}{c}{ Total } & $\mathbf{1 7}$ & $\mathbf{1 0 0 , 0}$ & $\mathbf{8}$ & $\mathbf{1 0 0 , 0}$ & $\mathbf{1 7}$ & $\mathbf{1 0 0 , 0}$ & $\mathbf{4 2}$ & $\mathbf{1 0 0 , 0}$
\end{tabular}

Não foram observadas diferenças estatísticas significativas, pelo teste "Z" a 5\%, nos percentuais indicados em uma mesma linha.

Os resultados quanto à ocorrência de $S$. aureus de acordo com a CCS do leite de mistura encontram-se na Tabela 19. Utilizou-se como critério de divisão dos grupos o limite máximo de CCS permitido pela IN 51, de 600.000 céls $/ \mathrm{mL}$ para leite B. Não foi verificada diferença estatística significativa entre os grupos, indicando que tanto propriedades com CCS acima do limite crítico, como propriedades em condições adequadas em relação a este parâmetro, podem veicular $S$. aureus através do leite de mistura. Os resultados obtidos no presente experimento são, portanto, diferentes dos dados reportados por Jayahao et al. (2004), os quais afirmam que o isolamento de $S$. aureus está associado à CCS do leite de mistura. Os autores observaram que em rebanhos infectados por S. aureus, apresentaram a CCS do leite de mistura entre 250.000 a 400.000 céls $/ \mathrm{mL}$.

No entanto, em valores absolutos, a ocorrência de S. aureus foi maior (25\%) entre as propriedades em que o leite de mistura apresentou níveis acima de 600.000 céls $/ \mathrm{mL}$. 
Tabela 19: Número de amostras de leite de mistura, positivos para Staphylococcus aureus agrupados de acordo com a contagem de células somáticas.

\begin{tabular}{ccccccc}
\hline & \multicolumn{2}{c}{$<00.000$ céls $/ \mathbf{m L}$} & \multicolumn{2}{c}{$>\mathbf{6 0 0 . 0 0 0}$ céls $/ \mathbf{m L}$} & \multicolumn{2}{c}{ Total } \\
\hline & $\mathbf{N}$ & $\mathbf{\%}$ & $\mathbf{N}$ & $\mathbf{\%}$ & $\mathbf{N}$ & $\%$ \\
\hline S. aureus + & 3 & 13,6 & 5 & 25,0 & 8 & 19,0 \\
S. aureus - & 19 & 86,4 & 15 & 75,0 & 34 & 81,0 \\
\hline Total & $\mathbf{2 2}$ & $\mathbf{1 0 0 , 0}$ & $\mathbf{2 0}$ & $\mathbf{1 0 0 , 0}$ & $\mathbf{4 2}$ & $\mathbf{1 0 0 , 0}$
\end{tabular}

Não foram observadas diferenças estatísticas significativas, pelo teste "Z" a 5\%, nos percentuais indicados em uma mesma linha.

A seguir, na Tabela 20 estão dispostos os resultados da ocorrência de $S$. aureus em relação à contagem de aeróbios mesófilos no leite de mistura. Da mesma forma que na CCS, utilizou-se como critério de divisão dos grupos o limite máximo permitido pela IN 51 para leite $B(500.000 \mathrm{UFC} / \mathrm{mL})$.

Não houve diferença estatística em relação à ocorrência de $S$. aureus e a contagem de mesófilos. No entanto, em valores absolutos, a ocorrência de $S$. aureus foi maior $(21,5 \%)$ em propriedades em que o leite de mistura apresentou níveis acima de 500.000 UFC/mL. Este resultado indica uma possível relação negativa entre a ocorrência de S. aureus e a qualidade do leite de mistura, ou seja, quanto menos adequadas forem as condições higiênico-sanitárias de obtenção do leite nas propriedades leiteiras, maior será o risco da presença de $S$. aureus no leite de mistura.

Tabela 20: Número de amostras de leite de mistura, positivos para Staphylococcus aureus agrupados de acordo com a contagem de aeróbios mesófilos.

\begin{tabular}{|c|c|c|c|c|c|c|}
\hline & \multicolumn{2}{|c|}{$<500.000$ UFC/mL } & \multicolumn{2}{|c|}{$>500.000$ UFC/mL } & \multicolumn{2}{|c|}{ Total } \\
\hline & $\mathbf{N}$ & $\%$ & $\mathbf{N}$ & $\%$ & $\mathbf{N}$ & $\%$ \\
\hline S. aureus + & 2 & 14,3 & 6 & 21,5 & 8 & 19,0 \\
\hline S. aureus - & 12 & 85,7 & 22 & 78,5 & 34 & 81,0 \\
\hline Total & 14 & 100,0 & 28 & 100,0 & 42 & 100,0 \\
\hline
\end{tabular}

Não foram observadas diferenças estatísticas significativas, pelo teste "Z" a $5 \%$, nos percentuais indicados em uma mesma linha.

$\mathrm{Na}$ Tabela 21 estão dispostos os resultados quanto ao número de amostras de leite de mistura, positivos para $S$. aureus de acordo com o sistema de ordenha utilizado na propriedade (balde ao pé ou canalizado em sistema fechado). 
Tabela 21: Número de amostras de leite de mistura, positivos para Staphylococcus aureus agrupados de acordo com o tipo de sistema de ordenha utilizado.

\begin{tabular}{ccccccc}
\hline & \multicolumn{2}{c}{ Balde ao pé } & \multicolumn{2}{c}{ Canalizada } & \multicolumn{2}{c}{ Total } \\
\hline & $\mathbf{N}$ & $\mathbf{\%}$ & $\mathbf{N}$ & $\mathbf{\%}$ & $\mathbf{N}$ & $\mathbf{\%}$ \\
\hline S. aureus + & 4 & 22,2 & 4 & 16,7 & 8 & 19,0 \\
S. aureus - & 14 & 77,8 & 20 & 83,3 & 34 & 81,0 \\
\hline Total & $\mathbf{1 8}$ & $\mathbf{1 0 0 , 0}$ & $\mathbf{2 4}$ & $\mathbf{1 0 0 , 0}$ & $\mathbf{4 2}$ & $\mathbf{1 0 0 , 0}$
\end{tabular}

Não foram observadas diferenças estatísticas significativas, pelo teste "Z" a 5\%, nos percentuais indicados em uma mesma linha.

O número de amostras de leite de mistura, positivos para $S$. aureus nas propriedades avaliadas, classificadas de acordo com os procedimentos utilizados de higiene durante os processos de obtenção do leite, encontram-se dispostos nas Tabelas 22 a 27.

Tabela 22: Número de animais amostrados positivos para Staphylococcus aureus de acordo com a prática de pré dipping.

\begin{tabular}{cccccccc}
\hline & \multicolumn{3}{c}{ Pré Dipping } & \multicolumn{2}{c}{ Total } \\
\hline & \multicolumn{2}{c}{ Sim } & $\mathbf{N}$ & $\mathbf{N}$ & $\mathbf{0}$ & $\mathbf{N}$ & $\mathbf{0}$ \\
\hline S. aureus + & 7 & 26,0 & 1 & 6,6 & 8 & 19,0 \\
S. aureus - & 20 & 74,0 & 14 & 93,4 & 34 & 81,0 \\
\hline Total & $\mathbf{2 7}$ & $\mathbf{1 0 0 , 0}$ & $\mathbf{1 5}$ & $\mathbf{1 0 0 , 0}$ & $\mathbf{4 2}$ & $\mathbf{1 0 0 , 0}$ \\
\hline
\end{tabular}

Não foram observadas diferenças estatísticas significativas, pelo teste "Z" a 5\%, nos percentuais indicados em uma mesma linha.

Pode-se verificar que os procedimentos de higiene de ordenha, utilizados com o objetivo de prevenir mastites e contaminações decorrentes da ordenha e do ambiente em geral refletem melhor e mais eficientemente nos animais individualmente do que na higiene e qualidade do leite de mistura, pois existe todo o trajeto que o leite percorre até a chegada ao tanque de expansão, sendo assim mais um interferente na contaminação microbiológica inicial do leite cru. 
Tabela 23: Número de animais amostrados positivos para Staphylococcus aureus de acordo com a prática de pós dipping.

\begin{tabular}{|c|c|c|c|c|c|c|}
\hline \multicolumn{7}{|c|}{ Pós Dipping } \\
\hline & \multicolumn{2}{|c|}{ Sim } & \multicolumn{2}{|c|}{ Não } & \multicolumn{2}{|c|}{ Total } \\
\hline & $\mathbf{N}$ & $\%$ & $\mathbf{N}$ & $\%$ & $\mathbf{N}$ & $\%$ \\
\hline S. aureus + & 6 & 21,4 & 2 & 14,3 & 8 & 19,0 \\
\hline S. aureus - & 22 & 78,6 & 12 & 85,7 & 34 & 81,0 \\
\hline Total & 28 & 100,0 & 14 & 100,0 & 42 & 100,0 \\
\hline
\end{tabular}

Não foram observadas diferenças estatísticas significativas, pelo teste "Z" a $5 \%$, nos percentuais indicados em uma mesma linha.

Tabela 24: Número de animais amostrados positivos para Staphylococcus aureus de acordo com a prática de uso de luvas descartáveis durante a ordenha.

\begin{tabular}{|c|c|c|c|c|c|c|}
\hline \multicolumn{7}{|c|}{ Luvas descartáveis } \\
\hline & \multicolumn{2}{|c|}{ Sim } & \multicolumn{2}{|c|}{ Não } & \multicolumn{2}{|c|}{ Total } \\
\hline & $\mathbf{N}$ & $\%$ & $\mathbf{N}$ & $\%$ & $\mathbf{N}$ & $\%$ \\
\hline S. aureus + & 3 & 21,4 & 5 & 18,0 & 8 & 19,0 \\
\hline S. aureus - & 11 & 78,6 & 23 & 82,0 & 34 & 81,0 \\
\hline Total & 14 & 100,0 & 28 & 100,0 & 42 & 100,0 \\
\hline
\end{tabular}

Não foram observadas diferenças estatísticas significativas, pelo teste "Z" a 5\%, nos percentuais indicados em uma mesma linha.

Tabela 25: Número de animais amostrados positivos para Staphylococcus aureus de acordo com o uso do teste da caneca de fundo preto para detecção de mastite clínica.

\begin{tabular}{|c|c|c|c|c|c|c|}
\hline \multicolumn{7}{|c|}{ Teste da caneca de fundo preto } \\
\hline & \multicolumn{2}{|c|}{ Sim } & \multicolumn{2}{|c|}{ Não } & \multicolumn{2}{|c|}{ Total } \\
\hline & $\mathbf{N}$ & $\%$ & $\mathbf{N}$ & $\%$ & $\mathbf{N}$ & $\%$ \\
\hline S. aureus + & 7 & 26,0 & 1 & 6,6 & 8 & 19,0 \\
\hline S. aureus - & 20 & 74,0 & 14 & 93,4 & 34 & 81,0 \\
\hline Total & 27 & 100,0 & 15 & 100,0 & 42 & 100,0 \\
\hline
\end{tabular}

Não foram observadas diferenças estatísticas significativas, pelo teste "Z" a $5 \%$, nos percentuais indicados em uma mesma linha. 
Tabela 26: Número de animais amostrados positivos para Staphylococcus aureus de acordo com a prática de desinfecção de teteiras.

\begin{tabular}{|c|c|c|c|c|c|c|}
\hline \multicolumn{7}{|c|}{ Desinfecção de Teteiras } \\
\hline & \multicolumn{2}{|c|}{ Sim } & \multicolumn{2}{|c|}{ Não } & \multicolumn{2}{|c|}{ Total } \\
\hline & $\mathbf{N}$ & $\%$ & $\mathbf{N}$ & $\%$ & $\mathbf{N}$ & $\%$ \\
\hline S. aureus + & 0 & 0,0 & 8 & 24,2 & 8 & 19,0 \\
\hline S. aureus - & 9 & 100,0 & 25 & 75,8 & 34 & 81,0 \\
\hline Total & 9 & 100,0 & 33 & 100,0 & 42 & 100,0 \\
\hline
\end{tabular}

Não foram observadas diferenças estatísticas significativas, pelo teste "Z" a 5\%, nos percentuais indicados em uma mesma linha.

Tabela 27: Número de animais amostrados positivos para Staphylococcus aureus de acordo com o tipo de desinfetante utilizado no pré e pós dipping.

\begin{tabular}{ccccccccc}
\hline & \multicolumn{9}{c}{ Desinfetantes } \\
\hline & \multicolumn{2}{c}{ lodo } & \multicolumn{2}{c}{ Cloro } & \multicolumn{2}{c}{ Nenhum } & \multicolumn{2}{c}{ Total } \\
\hline & $\mathbf{N}$ & $\mathbf{\%}$ & $\mathbf{N}$ & $\mathbf{0}$ & $\mathbf{N}$ & $\mathbf{\%}$ & $\mathbf{N}$ & $\mathbf{\%}$ \\
\hline S. aureus + & 5 & 18,0 & 2 & 40,0 & 1 & 11,1 & 8 & 19,0 \\
S. aureus - & 23 & 82,0 & 3 & 60,0 & 8 & 88,9 & 34 & 81,0 \\
\hline Total & $\mathbf{2 8}$ & $\mathbf{1 0 0 , 0}$ & $\mathbf{5}$ & $\mathbf{1 0 0 , 0}$ & $\mathbf{9}$ & $\mathbf{1 0 0 , 0}$ & $\mathbf{4 2}$ & $\mathbf{1 0 0 , 0}$ \\
\hline
\end{tabular}

Não foram observadas diferenças estatísticas significativas, pelo teste "Z" a 5\%, nos percentuais indicados em uma mesma linha.

5.4 Identificação dos isolados enterotoxigênicos de S. aureus no leite individual e no leite de mistura

Em um total de 660 amostras analisadas, sendo 618 amostras de leite individual e 42 amostras de leite de mistura, detectou-se 41 amostras de leite positivas para S. aureus $(6,2 \%)$. No entanto, em algumas amostras de leite foram detectados mais de um isolado, gerando 53 isolados, entre amostras de leite individual e leite de mistura neste estudo.

Para a identificação dos S. aureus produtores de enterotoxinas e de TSST-1 utilizaram-se 40 isolados, dentre eles, 30 provenientes de 21 amostras de leite individual (animais) e 10 provenientes de 8 amostras de leite de mistura.

Na Tabela 28 estão dispostos os resultados quanto à identificação dos isolados de $S$. aureus produtores de toxinas de acordo com o número de amostras analisadas (leite individual e de mistura). Verificou-se que das 21 amostras analisadas de leite individual em 
uma $(4,7 \%)$ foi detectada concomitantemente as enterotoxinas B e C, em uma $(4,7 \%)$ as toxinas A e TSST-1 e em $2(14,3 \%)$ amostras foram encontradas a toxina TSST-1.

Isolados de S. aureus produtores de toxinas são uma preocupação por várias razões. Primeiramente, estas toxinas são consideradas superantígenos que modulam a resposta imune e afetam a saúde animal. Outra razão é a preocupação com a Saúde Pública, pois estas toxinas podem estar envolvidas nas DVAs.

Sá et al. (2004) não detectou TSST-1 em suas amostras de leite individual proveniente de casos de mastite, no entanto, a produção de enterotoxinas foi detectada em nove amostras de leite $(4,39 \%)$, sendo uma $(0,49 \%)$ produtora da enterotoxina $D$, três $(1,46 \%)$ produtoras da enterotoxina $\mathrm{C}$ e três $(1,46 \%)$ produtoras de enterotoxina $\mathrm{B}$.

Quanto ao leite de mistura, foram detectadas no presente estudo duas amostras (25\%) contendo a somente toxina TSST-1. Araujo et al. (1989) encontraram apenas uma amostra $(0,5 \%)$ de $S$. aureus enterotoxigênica em leite cru proveniente de tanque de expansão. Em outro estudo realizado no Brasil, em 127 isolados de S. aureus procedentes de mastite subclínica foram encontradas seis $(4,7 \%)$ produtores de enterotoxinas, sendo um produtor da enterotoxina $C$, um da enterotoxina $A$ e três de $A$ e $C$ concomitantemente (LOPES et al. 1990).

Tabela 28: Freqüência de detecção de toxinas de isolados de $S$. aureus testados em amostras de leite individual e leite de mistura.

\begin{tabular}{ccccccc}
\hline \multirow{2}{*}{ Toxinas } & \multicolumn{2}{c}{ Leite Individual $^{\mathbf{2}}$} & \multicolumn{2}{c}{ Leite de Mistura } & \multicolumn{2}{c}{ Total $^{\mathbf{3}}$} \\
\cline { 2 - 7 } & Positivas & $\%$ & Positivas & $\%$ & Positivas & $\%$ \\
\hline A & 0 & 0,0 & 0 & 0,0 & 0 & 0,0 \\
B & 0 & 0,0 & 0 & 0,0 & 0 & 0,0 \\
C & 0 & 0,0 & 0 & 0,0 & 0 & 0,0 \\
D & 0 & 0,0 & 0 & 0,0 & 0 & 0,0 \\
B + C & 1 & 4,7 & 0 & 0,0 & 1 & 3,5 \\
A + TSST-1 & 1 & 4,7 & 0 & 0,0 & 1 & 3,5 \\
TSST-1 & 2 & 14,3 & 2 & 25,0 & 4 & 13,8 \\
\hline Total & $\mathbf{4}$ & $\mathbf{1 9 , 0}$ & $\mathbf{2}$ & $\mathbf{2 5 , 0}$ & $\mathbf{6}$ & $\mathbf{2 0 , 7}$
\end{tabular}

${ }^{1}$ Total de amostras analisadas: $21 ;{ }^{2}$ Total de amostras analisadas: $8 ;{ }^{3}$ Total de amostras analisadas: 29.

Segundo Cardoso et al. (2000), que descreveram pela primeira vez a produção da toxina TSST-1 por S. aureus isolado de mastite subclínica, no Brasil, é possível que esta toxina apresente fator de virulência importante em casos graves de mastite. Os autores relatam que a co-produção de diferentes tipos de toxinas pode aumentar os efeitos toxigênicos desses antígenos, sugerindo que esta co-produção de toxinas seja importante 
na patogenia das mastites. No presente estudo, não houve relação entre a presença de mastite clínica e subclínica e a detecção das toxinas.

$\mathrm{Na}$ Tabela 29 está ilustrado o perfil bioquímico das amostras positivas para as toxinas estafilococócicas. Pode se observar que todas as amostras foram positivas para catalase, coagulase e termonuclease, porém entre a produção de acetoína (VP) e a maltose, houve divergência nos resultados.

Como critério de escolha dos isolados de $S$. aureus a serem testados utilizou-se a série bioquímica. De modo que, $13(32,5 \%)$ isolados apresentaram reação positiva em todas as provas utilizadas, $20(50 \%)$ isolados para catalase, coagulase, termonuclease e VP, $3(7,5 \%)$ isolados para catalase, coagulase, termonuclease e fermentação aeróbia de maltose e $4(10 \%)$ foram positivas apenas para catalase, coagulase e termonuclease e negativas para VP e fermentação aeróbia de maltose.

Tabela 29: Perfil bioquímico dos isolados de $S$. aureus positivos para as toxinas estafilococócicas.

\begin{tabular}{|c|c|c|c|c|c|}
\hline \multirow{2}{*}{$\begin{array}{c}\text { Isolados } \\
\text { produtores de } \\
\text { toxinas }\end{array}$} & \multicolumn{5}{|c|}{ Série Bioquímica } \\
\hline & Catalase & Coagulase & Termonuclease & $\mathbf{V P}^{1}$ & Maltose $^{2}$ \\
\hline$B+C$ & + & + & + & + & - \\
\hline$A+T S S T-1$ & + & + & + & + & - \\
\hline $\begin{array}{c}\text { TSST-1 leite } \\
\text { individual }\end{array}$ & + & + & + & + & - \\
\hline $\begin{array}{c}\text { TSST-1 leite } \\
\text { individual }\end{array}$ & + & + & + & - & + \\
\hline $\begin{array}{l}\text { TSST-1 leite de } \\
\text { mistura }\end{array}$ & + & + & + & - & + \\
\hline $\begin{array}{l}\text { TSST-1 leite de } \\
\text { mistura }\end{array}$ & + & + & + & - & + \\
\hline
\end{tabular}

${ }^{1}$ Produção de Acetoína $\left(37^{\circ} \mathrm{C}, 48\right.$ horas $) ;{ }^{2}$ Fermentação aeróbia da maltose $\left(37^{\circ} \mathrm{C}, 48\right.$ horas).

Sá et al. (2004) detectaram que dos 209 isolados de S. aureus, 205 (98,86\%) foram positivos para a termonuclease, resultado semelhante ao encontrado por De Freitas e Magalhães (1990), que detectaram esta enzima em $91,4 \%$ dos isolados. No presente estudo, utilizou-se rigorosamente este critério de positividade para os isolados a serem testados, pois de acordo com Bergdoll (1989) e Bennett (1996) esta enzima é um forte indicativo da produção de toxinas pelo $S$. aureus. 
A diversidade de provas bioquímicas utilizadas para identificação deste agente entre amostras de leite provenientes de mastite e a falta de consenso entre os pesquisadores de quais provas seriam melhores e mais confiáveis, evidencia que somente a serie bioquímica para identificar $S$. aureus é insuficiente e que técnicas de genotipagem seriam necessárias para melhor interpretação dos resultados.

\subsection{Identificação genotípica dos isolados de S. aureus}

Para se conseguir relacionar a origem epidemiológica dos $S$. aureus encontrados nas 42 propriedades leiteiras nas duas regiões de abrangência do presente estudo, avaliouse 35 isolados.

O aparelho de foto documentação utilizado no procedimento permite a análise de 13 isolados por vez. Desta forma, os isolados foram divididos em 3 grupos com 13 cada. Os S. aureus do Grupo 1 (1 a 13) estão especificadas na Tabela 30 , quanto à fazenda, região e origem das amostras de leite.

A leitura da PFGE dos isolados do Grupo 1 pode ser visualizada na Figura 13. Pode-se observar que os isolados $1,3,7,8,9,11$ e 13 não apresentaram bandas, não sendo, portanto considerados como S. aureus. Isto pode estar relacionado à contaminação após o isolamento, ou à baixa especificidade das técnicas de identificação bioquímica.

Os isolados 4 (amostra de leite individual) e 5 (amostra de leite de mistura) visualizados na Figura 13, oriundos da mesma propriedade leiteira apresentaram similaridade genotípica, comprovando a transferência de $S$. aureus de um animal infectado para o leite de mistura. Da mesma forma, os isolados 2 (amostra de leite individual) e 12 (amostra de leite de mistura) oriundos de propriedades diferentes, porém pertencentes a mesma região (Ribeirão Preto) também apresentaram bandas semelhantes, logo, apresentando similaridade genética (Figura 13). A disseminação de S. aureus entre diferentes propriedades, possivelmente pode ter sido através da troca ou venda de animais entre as propriedades ou devido a falhas decorrentes dos procedimentos de coleta de leite, visto que ambas as propriedades entregavam o leite na mesma cooperativa. 
Tabela 30: Especificação dos isolados de S. aureus analisados por PFGE no Grupo 1, quanto à fazenda, região e origem da amostra de leite.

\begin{tabular}{cccc}
\hline Isolados S. aureus & Fazenda & Região & Origem do leite \\
\hline 1 & 2 & $1^{\text {a }}$ & Individual \\
2 & 22 & $2^{\text {b }}$ & Individual \\
3 & 22 & 2 & Individual \\
4 & 3 & 1 & Individual \\
5 & 3 & 1 & Mistura \\
6 & 5 & 1 & Individual \\
7 & 8 & 1 & Individual \\
8 & 8 & 1 & Individual \\
9 & 9 & 1 & Mistura \\
10 & 23 & 2 & Individual \\
11 & 23 & 2 & Individual \\
12 & 23 & 2 & Mistura \\
13 & 14 & 1 & Individual
\end{tabular}

a Propriedades pertencentes à região de São Carlos; ${ }^{b}$ Propriedades pertencentes à região de Ribeirão Preto.

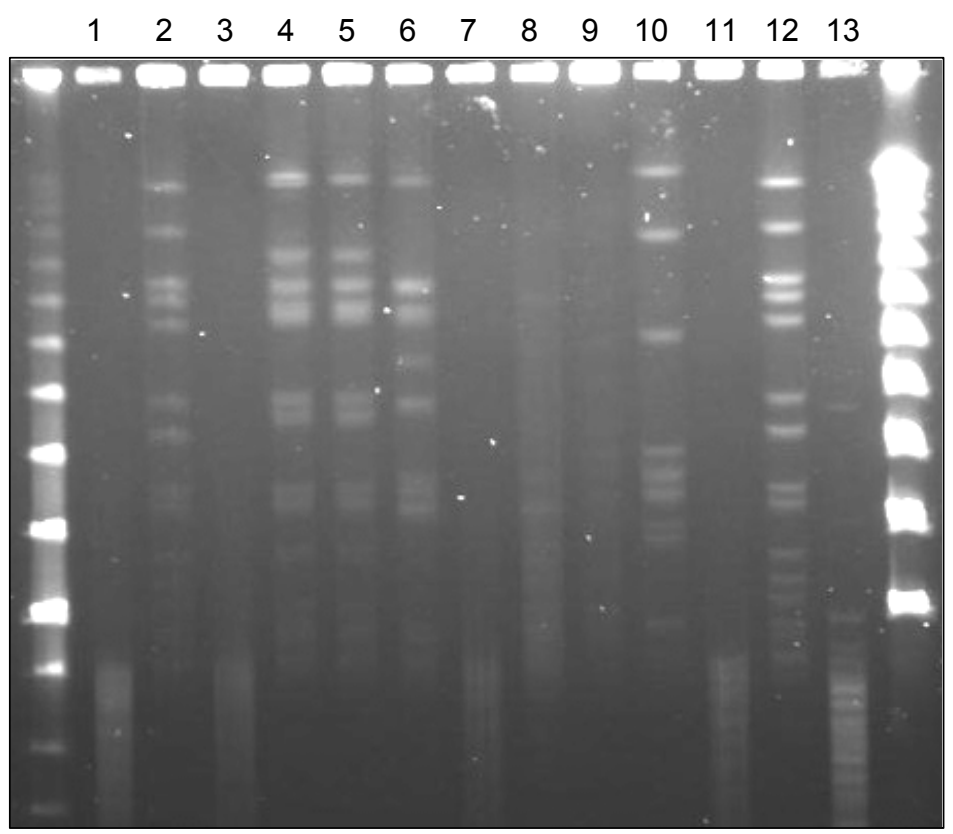

FIGURA 13: Leitura da PFGE do grupo 1 (isolados de $S$. aureus de 1 a 13). Seqüência da esquerda para direita: padrão lambda, isolados $1,2,3,4,5,6,7,8,9,10,11,12$ e 13, padrão concatâmeros. 
Os isolados de S. aureus do Grupo 2 (14 a 26) estão especificadas na Tabela 31, quanto à fazenda, região e origem das amostras. A leitura da PFGE pode ser visualizada na Figura 14. Similarmente ao que ocorreu na análise do Grupo 1, alguns isolados não apresentaram banda (isolados 14, 15, 16, 18, 24, 25 e 26).

Os isolados 19, 20, 21 e 22, provenientes de amostras de leite de mistura de uma mesma propriedade, foram todos similares, indicando não haver diversidade genética entre os isolados de S. aureus encontrados nesta propriedade. Este resultado demonstra um possível caráter endêmico de infecções intramamárias (mastites) neste rebanho, uma vez que os isolados de $S$. aureus eram todos similares geneticamente.

Tabela 31: Especificação dos isolados de S. aureus analisados por PFGE no Grupo 2, quanto à fazenda, região e tipo de amostra de leite.

\begin{tabular}{cccc}
\hline Isolados S. aureus & Fazenda & Região & Origem do leite \\
\hline 14 & 25 & $2^{\text {a }}$ & Individual \\
15 & 26 & 2 & Individual \\
16 & 17 & $1^{\text {b }}$ & Mistura \\
17 & 17 & 1 & Mistura \\
18 & 17 & 1 & Mistura \\
19 & 29 & 2 & Mistura \\
20 & 29 & 2 & Mistura \\
21 & 29 & 2 & Mistura \\
22 & 29 & 2 & Mistura \\
23 & 19 & 1 & Individual \\
24 & 20 & 1 & Mistura \\
25 & 33 & 2 & Individual \\
26 & 33 & 2 & Individual \\
\hline
\end{tabular}

a Propriedades pertencentes à região de Ribeirão Preto; ${ }^{\text {b }}$ Propriedades pertencentes à região de São Carlos. 


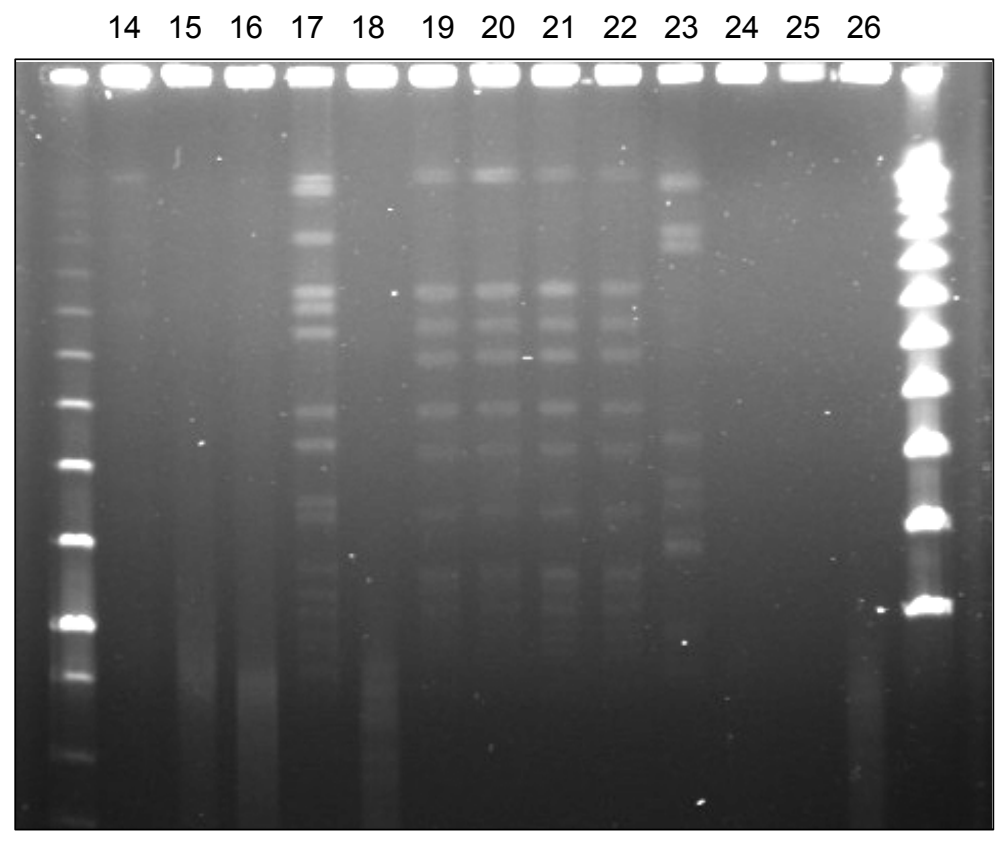

FIGURA 14: Leitura da PFGE do grupo 2 (isolados de S. aureus 14 a 26). Seqüência da esquerda para direita: padrão lambda, isolados 14, 15, 16, 17, 18, 19, 20, 21, 22, 23, 24, 25 e 26, padrão concatâmeros.

Os isolados de S. aureus do Grupo 3 (27 a 35), analisados através da PFGE, estão especificados na Tabela 32.

Tabela 32: Especificação dos isolados de S. aureus analisados por PFGE no Grupo 3, quanto à fazenda, região, tipo de amostra de leite.

\begin{tabular}{cccc}
\hline Isolados S. aureus & Fazenda & Região & Origem do leite \\
\hline 27 & 36 & $2^{\text {a }}$ & Individual \\
28 & 37 & 2 & Individual \\
29 & 38 & 2 & Individual \\
30 & 38 & 2 & Individual \\
31 & 41 & 2 & Individual \\
32 & 41 & 2 & Individual \\
33 & 41 & 2 & Mistura \\
34 & 42 & 2 & Individual \\
35 & 42 & 2 & Mistura \\
\hline
\end{tabular}

\footnotetext{
${ }^{\mathrm{a}}$ Propriedades pertencentes à região de Ribeirão Preto.
} 
A leitura do gel de agarose do Grupo 3 pode ser visualizada na Figura 15. Similarmente ao que ocorreu na análise do Grupo 1, alguns isolados não apresentaram banda (isolados 33, 34, 35). Com relação aos isolados que apresentaram bandas no gel, não foi observada nenhuma similaridade entre eles.

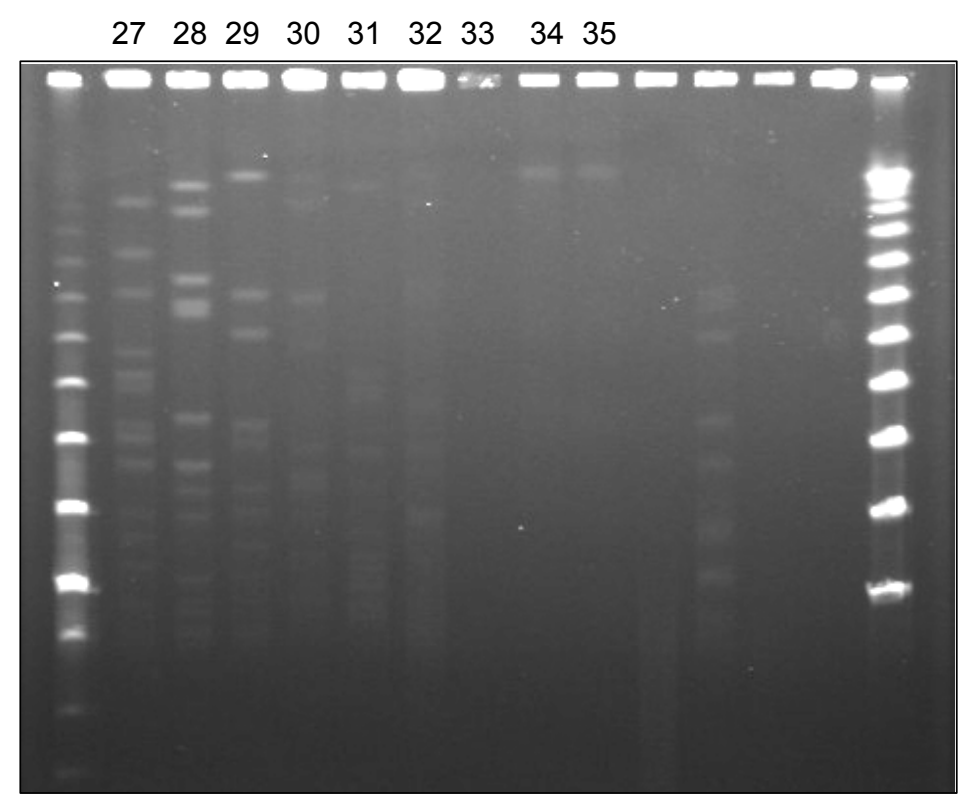

FIGURA 15: Leitura da PFGE do grupo 3 (isolados de S. aureus de 27 a 35). Seqüência da esquerda para direita: padrão lambda, isolados $27,28,29,30,31,32,33,34,35$, padrão concatâmeros.

$\mathrm{Na}$ Tabela 33 estão apresentados os 13 padrões distintos encontrados para os isolados de Staphylococcus aureus do leite de mistura e individual provenientes das 42 propriedades leiteiras avaliadas.

Houve heterogeneidade genética entre os isolados, visto o grande número de padrões encontrados. A elevada variabilidade entre os padrões fenotípicos e genotípicos pode decorrer da diversidade dos locais nos quais os $S$. aureus são encontrados, uma vez que estes microrganismos podem ser isolados do leite de vacas acometidas de mastite clínica e subclínica, da superfície da pele dos tetos, dos conjuntos de teteiras utilizados para a ordenha, e dos ordenhadores (ROBERSON et al. 1994).

Devido à contaminação de alguns $S$. aureus utilizados na análise, o número de isolados na população-teste foi reduzida de 35 para 18. Assim, a capacidade discriminatória do método de PFGE entre as amostras analisadas foi de $D=0,95$, demonstrando a eficácia do método para a identificação genotípica desta espécie. 
Tabela 33: Padrões de identificação de Staphylococcus aureus isolados de vacas leiteiras e tanques de resfriamento.

\begin{tabular}{cc}
\hline Padrões & Isolados \\
\hline 1 & 2 e 12 \\
2 & 4 e 5 \\
3 & 6 \\
4 & 10 \\
5 & 17 \\
6 & $19,20,21$ e 22 \\
7 & 23 \\
8 & 27 \\
9 & 28 \\
10 & 29 \\
11 & 30 \\
12 & 31 \\
13 & 32 \\
\hline
\end{tabular}

5.6 Isolamento e identificação de Escherichia coli O157: $\mathrm{H} 7$

5.6.1 Amostras de leite Individual (vacas leiteiras em produção)

O número de animais amostrados e o número de animais positivos para $E$. coli 0157: H7 em cada propriedade de acordo com a região avaliada encontram-se na Tabela 34. Na região 1 (São Carlos) foram amostrados 307 animais, sendo que 3 (1\%) foram positivos para E. coli O157: H7. Na região 2 (Ribeirão Preto) foram avaliados 311 animais e $5(1,6 \%)$ foram positivos para E. coli O157: H7.

Pode-se verificar que a taxa de isolamento de E. coli 0157 : $\mathrm{H} 7$ foi muito baixa nas condições em que este estudo foi desenvolvido. Segundo Forsythe (2002), a E. coli 0157: H7 pode se abrigar nas fezes do bovino durante um período médio de 21 dias, podendo variar de 5 a 124 dias e este pode ser considerado o portador desta bactéria por longos períodos. No entanto, como causadora de mastite e principalmente mastite subclínica, a E. coli O157: H7 não parece ser um agente importante.

Os resultados encontrados na literatura quanto a $E$. coli causar mastite clínica e/ou subclínica, sua intensidade e duração são bastante controversos (COSTA et al. (1998); CULLOR (1993); DUNN (1994); DOPFER et al. (1999); BRADLEY e GREEN (2000)). Estes autores relatam que normalmente os casos de mastite causados por $E$. coli se manifestam 
de forma clínica e aguda, porém afirmam que pode haver casos subclínicos e a $E$. coli persistir na glândula mamária por longos períodos.

No entanto, poucos estudos relatam o sorotipo 0157: H7 como causadora de mastite bovina. Stephen e Kuhn (1999) encontraram 6\% de E. coli em amostras de leite obtidas assepticamente de quartos mamários de diferentes animais com mastite clínica aguda. Destes isolados de E. coli, 2,8\% foram confirmados como ECVT.

Tabela 34: Número de animais amostrados por região e por fazenda e o número de animais positivos encontrado em cada propriedade para E. coli O157: $\mathrm{H} 7$.

\begin{tabular}{|c|c|c|c|c|c|c|c|}
\hline \multicolumn{4}{|c|}{ Região 1} & \multicolumn{4}{|c|}{ Região 2} \\
\hline Fazenda & $\begin{array}{c}N \text { animais } \\
\text { amostrados }\end{array}$ & $\begin{array}{c}\text { O157: H7 } \\
+\end{array}$ & $\%$ & Fazenda & $\begin{array}{c}N \text { animais } \\
\text { amostrados }\end{array}$ & $\begin{array}{c}\text { O157: H7 } \\
+\end{array}$ & $\%$ \\
\hline 1 & 9 & 0 & 0,0 & 22 & 13 & 2 & 15,4 \\
\hline 2 & 14 & 0 & 0,0 & 23 & 20 & 1 & 5,0 \\
\hline 3 & 15 & 0 & 0,0 & 24 & 20 & 0 & 0,0 \\
\hline 4 & 20 & 0 & 0,0 & 25 & 20 & 0 & 0,0 \\
\hline 5 & 20 & 0 & 0,0 & 26 & 20 & 0 & 0,0 \\
\hline 6 & 2 & 0 & 0,0 & 27 & 20 & 0 & 0,0 \\
\hline 7 & 20 & 0 & 0,0 & 28 & 12 & 0 & 0,0 \\
\hline 8 & 8 & 0 & 0,0 & 29 & 3 & 0 & 0,0 \\
\hline 9 & 16 & 0 & 0,0 & 30 & 5 & 0 & 0,0 \\
\hline 10 & 20 & 0 & 0,0 & 31 & 20 & 0 & 0,0 \\
\hline 11 & 17 & 0 & 0,0 & 32 & 20 & 0 & 0,0 \\
\hline 12 & 14 & 0 & 0,0 & 33 & 15 & 0 & 0,0 \\
\hline 13 & 11 & 0 & 0,0 & 34 & 10 & 0 & 0,0 \\
\hline 14 & 11 & 0 & 0,0 & 35 & 20 & 2 & 10,0 \\
\hline 15 & 9 & 0 & 0,0 & 36 & 15 & 0 & 0,0 \\
\hline 16 & 16 & 0 & 0,0 & 37 & 18 & 0 & 0,0 \\
\hline 17 & 18 & 0 & 0,0 & 38 & 15 & 0 & 0,0 \\
\hline 18 & 19 & 0 & 0,0 & 39 & 12 & 0 & 0,0 \\
\hline 19 & 20 & 3 & 15,0 & 40 & 11 & 0 & 0,0 \\
\hline 20 & 9 & 0 & 0,0 & 41 & 12 & 0 & 0,0 \\
\hline 21 & 19 & 0 & 0,0 & 42 & 10 & 0 & 0,0 \\
\hline Total & 307 & 3 & 1,0 & Total & 311 & 5 & 1,6 \\
\hline
\end{tabular}

Não foram observadas diferenças estatisticas significativas, pelo teste "Z" a 5\%, nos percentuais totais indicados na última linha. 
A distribuição dos animais positivos para E. coli O157: H7 de acordo com o volume de produção de leite (L/dia) na propriedade encontra-se na Tabela 35. Não houve diferença estatística entre os grupos avaliados. Entretanto, as propriedades do grupo de menor produção (< 400 L/dia) não apresentaram amostras positivas para E. coli O157: H7, enquanto que as propriedades de média e alta produção apresentaram taxas de ocorrência de E. coli O157: $\mathrm{H} 7$ bastante semelhantes.

Tabela 35: Número de animais amostrados positivos para E. coli O157: $\mathrm{H} 7$ de acordo com o volume de leite produzido na propriedade (L/dia).

\begin{tabular}{ccccccccc}
\hline & \multicolumn{2}{c}{$<\mathbf{4 0 0}$ L/dia } & \multicolumn{2}{c}{$\mathbf{4 0 0}-\mathbf{1 . 0 0 0}$ L/dia } & \multicolumn{2}{c}{$\mathbf{1 . 0 0 0}$ L/ dia } & \multicolumn{2}{c}{ Total } \\
\hline & $\mathbf{N}$ & $\mathbf{\%}$ & $\mathbf{N}$ & $\mathbf{\%}$ & $\mathbf{N}$ & $\mathbf{\%}$ & $\mathbf{N}$ & $\mathbf{\%}$ \\
\hline O157: H7 + & 0 & 0,0 & 2 & 2,0 & 6 & 1,8 & 8 & 1,3 \\
O157: H7 - & 194 & 100,0 & 97 & 98,0 & 319 & 98,2 & 610 & 98,7 \\
\hline Total & $\mathbf{1 9 4}$ & $\mathbf{1 0 0 , 0}$ & $\mathbf{9 9}$ & $\mathbf{1 0 0 , 0}$ & $\mathbf{3 2 5}$ & $\mathbf{1 0 0 , 0}$ & $\mathbf{6 1 8}$ & $\mathbf{1 0 0 , 0}$
\end{tabular}

Não foram observadas diferenças estatísticas significativas, pelo teste "Z" a 5\%, nos percentuais indicados em uma mesma linha.

Em relação à contagem de células somáticas (CCS), as propriedades foram categorizadas da mesma maneira descrita para S. aureus: Grupo de baixa CCS $(<200.000$ céls / mL de leite - ausência de processo inflamatório) e Grupo de alta CCS (> 200.000 céls / $\mathrm{mL}$ de leite - presença de qualquer grau de mastite subclínica). O número de animais positivos encontrados em cada grupo está apresentado na Tabela 36. Pode-se observar que, dos 8 animais positivos para $E$. coli 0157: $\mathrm{H} 7$ encontrados neste estudo, 7 deles apresentaram CCS acima de 200.000 céls $/ \mathrm{mL}$, indicando que estes animais, em que foi isolado $E$. coli $\mathrm{O} 157: \mathrm{H}$, possuíam algum grau de processo inflamatório no momento da colheita das amostras. Os dados obtidos no experimento indicam que a ocorrência de $E$. coli 0157: H7 no leite, embora pequena, é preocupante, uma vez que os animais com mastite subclínica causada por este agente representam uma importante fonte de infecção para o rebanho e para o leite de mistura da propriedade. 
Tabela 36: Número de animais amostrados positivos para E. coli $\mathrm{O} 157$ : $\mathrm{H} 7$ de acordo com a contagem de células somáticas (CCS).

\begin{tabular}{ccccccc}
\hline & \multicolumn{2}{c}{$\mathbf{2 0 0 . 0 0 0}$ céls/mL } & \multicolumn{2}{c}{$>\mathbf{2 0 0 . 0 0 0}$ céls/mL } & \multicolumn{2}{c}{ Total } \\
\hline & $\mathbf{N}$ & $\mathbf{9}$ & $\mathbf{N}$ & $\mathbf{\%}$ & $\mathbf{N}$ & $\%$ \\
\hline O157: H7 + & 1 & 0,6 & 7 & 1,5 & 8 & 1,3 \\
O157: H7 - & 159 & 99,4 & 451 & 98,5 & 610 & 98,7 \\
\hline Total & $\mathbf{1 6 0}$ & $\mathbf{1 0 0 , 0}$ & $\mathbf{4 5 8}$ & $\mathbf{1 0 0 , 0}$ & $\mathbf{6 1 8}$ & $\mathbf{1 0 0 , 0}$
\end{tabular}

Não foram observadas diferenças estatisticas significativas, pelo teste "Z" a $5 \%$, nos percentuais indicados em uma mesma linha.

O número de animais positivos para E. coli $\mathrm{O} 157$ : $\mathrm{H} 7$ de acordo com o sistema de ordenha utilizado em cada propriedade está descrito na Tabela 37. Verificou-se que houve uma maior ocorrência de E. coli O157: $\mathrm{H} 7$ entre os animais ordenhados através de sistema canalizado, no entanto não foi detectada diferença estatística significativa entre os grupos testados.

Em valores absolutos, houve um maior isolamento de $E$. coli $\mathrm{O} 157: \mathrm{H} 7$ entre os animais ordenhados através de equipamentos canalizados (salas de ordenha com fosso). Deve-se ressaltar que a $E$. coli é considerada como um microrganismo de origem ambiental e, conseqüentemente, pode ser disseminado em todos os ambientes, incluindo a sala de ordenha. Assim, o equipamento de ordenha é uma fonte importante de contaminação do leite por este microrganismo, principalmente se houver falhas nos procedimentos de higienização, ou mesmo durante as operações de ordenha, através do contato direto do leite com as superfícies dos equipamentos contaminados.

Tabela 37: Número de animais amostrados positivos para E. coli $\mathrm{O} 157$ : $\mathrm{H} 7$ de acordo com o sistema de ordenha utilizado na propriedade.

\begin{tabular}{ccccccc}
\hline & \multicolumn{2}{c}{ Canalizada } & \multicolumn{2}{c}{ Balde ao pé } & \multicolumn{2}{c}{ Total } \\
\hline & $\mathbf{N}$ & $\mathbf{\%}$ & $\mathbf{N}$ & $\mathbf{\%}$ & $\mathbf{N}$ & $\%$ \\
\hline O157: $\mathrm{H7}+$ & 6 & 1,3 & 2 & 1,1 & 8 & 1,3 \\
O157: $\mathrm{H7}-$ & 439 & 98,7 & 169 & 98,9 & 610 & 98,7 \\
\hline Total & $\mathbf{4 4 7}$ & $\mathbf{1 0 0 , 0}$ & $\mathbf{1 7 1}$ & $\mathbf{1 0 0 , 0}$ & $\mathbf{6 1 8}$ & $\mathbf{1 0 0 , 0}$
\end{tabular}

Não foram observadas diferenças estatisticas significativas, pelo teste "Z" a 5\%, nos percentuais indicados em uma mesma linha. 
A E. coli O157: $\mathrm{H} 7$ pertence ao grupo de bactérias relacionadas à contaminação ambiental e é conhecida por seu comportamento oportunista. Desta forma, relacionou-se sua presença com as condições de higiene e práticas de ordenha encontradas nas propriedades avaliadas (Tabelas 38 a 43).

Dentre as práticas de ordenha, o pré dipping é a que mais controla a contaminação do leite e a ocorrência de mastite por bactérias de origem ambiental na rotina de ordenha. Na Tabela 38, estão dispostos os resultados quanto ao número de animais amostrados e positivos de acordo com esta prática. Não foi detectada diferença estatística entre a aplicação do pré dipping e a ocorrência de E. coli O157: H7. No entanto, pode-se verificar que a taxa de ocorrência de E. coli O157: $\mathrm{H} 7$ foi $50 \%$ menor entre os animais que eram submetidos a este procedimento.

Quanto à utilização do pré e pós dipping como importantes práticas de desinfecção e controle de mastite, pode-se notar, através do número de animais que ambas as práticas são freqüentemente utilizadas entre as propriedades avaliadas neste estudo.

Tabela 38: Número de animais amostrados positivos para E. coli O157: H7 de acordo com a prática de pré dipping.

\begin{tabular}{|c|c|c|c|c|c|c|}
\hline \multicolumn{7}{|c|}{ Pré Dipping } \\
\hline & \multicolumn{2}{|c|}{ Sim } & \multicolumn{2}{|c|}{ Não } & \multicolumn{2}{|c|}{ Total } \\
\hline & $\mathbf{N}$ & $\%$ & $\mathbf{N}$ & $\%$ & $\mathbf{N}$ & $\%$ \\
\hline O157: H7 + & 4 & 1,0 & 4 & 2,0 & 8 & 1,3 \\
\hline O157: H7 - & 410 & 99,0 & 200 & 98,0 & 610 & 98,7 \\
\hline Total & 414 & 100,0 & 204 & 100,0 & 618 & 100,0 \\
\hline
\end{tabular}

Não foram observadas diferenças estatisticas significativas, pelo teste "Z" a 5\%, nos percentuais indicados em uma mesma linha.

Tabela 39: Número de animais amostrados positivos para E. coli $\mathrm{O} 157$ : $\mathrm{H} 7$ de acordo com a prática de pós dipping.

Pós Dipping

\begin{tabular}{cccccccc}
\hline & \multicolumn{2}{c}{ Sim } & \multicolumn{2}{c}{ Não } & \multicolumn{2}{c}{ Total } \\
\hline & $\mathbf{N}$ & $\mathbf{9}$ & $\mathbf{N}$ & $\mathbf{\%}$ & $\mathbf{N}$ & $\%$ \\
\hline O157: H7 & 4 & 1,0 & 4 & 2,0 & 8 & 1,3 \\
O157: H7 - & 428 & 99,0 & 182 & 98,0 & 610 & 98,7 \\
\hline Total & $\mathbf{4 3 2}$ & $\mathbf{1 0 0 , 0}$ & $\mathbf{1 8 6}$ & $\mathbf{1 0 0 , 0}$ & $\mathbf{6 1 8}$ & $\mathbf{1 0 0 , 0}$
\end{tabular}

Não foram observadas diferenças estatisticas significativas, pelo teste "Z" a 5\%, nos percentuais indicados em uma mesma linha. 
Tabela 40: Número de animais amostrados positivos para $E$. coli $\mathrm{O} 157$ : $\mathrm{H} 7$ de acordo com a prática de uso de luvas descartáveis durante a ordenha.

Luvas descartáveis

\begin{tabular}{ccccccc}
\hline & \multicolumn{2}{c}{ Sim } & \multicolumn{2}{c}{ Não } & \multicolumn{2}{c}{ Total } \\
\hline & $\mathbf{N}$ & $\mathbf{N}$ & $\mathbf{N}$ & $\mathbf{\%}$ & $\mathbf{N}$ & $\%$ \\
\hline O157: H7 + & 3 & 1,2 & 5 & 1,3 & 8 & 1,3 \\
O157: H7 - & 245 & 98,8 & 365 & 98,7 & 610 & 98,7 \\
\hline Total & $\mathbf{2 4 8}$ & $\mathbf{1 0 0 , 0}$ & $\mathbf{3 7 0}$ & $\mathbf{1 0 0 , 0}$ & $\mathbf{6 1 8}$ & $\mathbf{1 0 0 , 0}$
\end{tabular}

Não foram observadas diferenças estatisticas significativas, pelo teste "Z" a 5\%, nos percentuais indicados em uma mesma linha.

Tabela 41: Número de animais amostrados positivos para E. coli $\mathrm{O} 157$ : $\mathrm{H} 7$ de acordo com o uso do teste da caneca de fundo preto para detecção de mastite clínica.

\begin{tabular}{ccccccc}
\hline \multicolumn{7}{c}{ Teste da caneca de fundo preto } \\
& \multicolumn{2}{c}{ Sim } & \multicolumn{3}{c}{ Não } & \multicolumn{2}{c}{ Total } \\
\hline & $\mathbf{N}$ & $\mathbf{N}$ & $\mathbf{N}$ & $\%$ & $\mathbf{N}$ & $\%$ \\
\hline O157: $\mathrm{H} 7+$ & 6 & 1,4 & 2 & 1,0 & 8 & 1,3 \\
O157: $\mathrm{H} 7-$ & 428 & 98,6 & 182 & 99,0 & 610 & 98,7 \\
\hline Total & $\mathbf{4 3 4}$ & $\mathbf{1 0 0 , 0}$ & $\mathbf{1 8 4}$ & $\mathbf{1 0 0 , 0}$ & $\mathbf{6 1 8}$ & $\mathbf{1 0 0 , 0}$
\end{tabular}

Não foram observadas diferenças estatisticas significativas, pelo teste "Z" a 5\%, nos percentuais indicados em uma mesma linha.

Tabela 42: Número de animais amostrados positivos para $E$. coli $\mathrm{O} 157$ : $\mathrm{H} 7$ de acordo com a prática de desinfecção de teteiras.

\begin{tabular}{cccccccc}
\hline & \multicolumn{9}{c}{ Desinfecção de Teteiras } & \multicolumn{2}{c}{ Total } \\
\hline & \multicolumn{2}{c}{ Sim } & $\mathbf{N}$ & $\mathbf{N}$ & $\mathbf{N a ̃ o}$ & $\mathbf{N}$ & $\%$ \\
\hline O157: H7 + & 3 & 2,0 & 5 & 1,0 & 8 & 1,3 \\
O157: H7 - & 144 & 98,0 & 466 & 99,0 & 610 & 98,7 \\
\hline Total & $\mathbf{1 4 7}$ & $\mathbf{1 0 0 , 0}$ & $\mathbf{4 7 1}$ & $\mathbf{1 0 0 , 0}$ & $\mathbf{6 1 8}$ & $\mathbf{1 0 0 , 0}$
\end{tabular}

Não foram observadas diferenças estatisticas significativas, pelo teste "Z" a 5\%, nos percentuais indicados em uma mesma linha. 
Tabela 43: Número de animais amostrados positivos para E. coli $\mathrm{O} 157$ : $\mathrm{H} 7$ de acordo com o tipo de desinfetante utilizado no pré e pós dipping.

\begin{tabular}{|c|c|c|c|c|c|c|c|c|}
\hline \multicolumn{9}{|c|}{ Desinfetantes } \\
\hline & \multicolumn{2}{|c|}{ Iodo } & \multicolumn{2}{|c|}{ Cloro } & \multicolumn{2}{|c|}{ Nenhum } & \multicolumn{2}{|c|}{ Total } \\
\hline & $\mathbf{N}$ & $\%$ & $\mathbf{N}$ & $\%$ & $\mathbf{N}$ & $\%$ & $\mathbf{N}$ & $\%$ \\
\hline O157: H7 + & 4 & 1,0 & 0 & 0,0 & 4 & 3,5 & 8 & 1,3 \\
\hline O157: H7 - & 434 & 99,0 & 65 & 100,0 & 111 & 96,5 & 610 & 98,7 \\
\hline Total & 438 & 100,0 & 65 & 100,0 & 115 & 100,0 & 618 & 100,0 \\
\hline
\end{tabular}

Não foram observadas diferenças estatísticas significativas, pelo teste "Z" a 5\%, nos percentuais indicados em uma mesma linha.

5.6.2 Amostras de leite de mistura (tanques de expansão)

A E. coli O157: H7 não foi detectada nas amostras de leite de mistura das 42 propriedades leiteiras avaliadas neste estudo.

A taxa de isolamento de E. coli $\mathrm{O} 157$ : $\mathrm{H} 7$, de acordo com vários autores, é baixa. Jayarao e Wang (1999) encontraram somente 7,3\% das amostras de leite contaminadas com E. coli, concluindo que o risco de contaminação do leite de mistura com E. coli patogênica é baixo. Estudos anteriores sobre a prevalência de isolados ECVT em amostras de leite cru indicaram valores de 3,8\% (JAYARAO e HENNING, 2001), 3,9\% (KLIE et al. 1997) e $0,87 \%$ (STEELE et al. 1997).

De acordo com Stephen e Kuhn (1999), significado especial na contaminação do leite com ECVT deve ser atribuído à contaminação fecal. No entanto, de acordo com os autores, em amostras de leite colhidas assepticamente de quartos mamários deve-se considerar os isolados de ECVT como possíveis causadores de mastites em vacas lactantes.

No presente estudo, a contagem presuntiva de E. coli O157: H7 em Agar MacConkey Sorbitol MUG no leite de mistura das propriedades avaliadas variou de $10^{3}$ a $10^{5}$ $\mathrm{UFC} / \mathrm{mL}$ de leite.

Segundo Silva et al. (2001), o principal método de isolamento de Escherichia coli 0157: H7 em alimentos consiste na observação de colônias típicas em ágar SorbitolMacConkey suplementado com MUG. No entanto, verifica-se que quando se emprega este meio na análise de leite in natura, outras bactérias não fermentadoras de sorbitol típicas deste alimento, como Proteus spp., Aeromonas spp. e outras E. coli, também se desenvolvem, levando a um excesso de colônias na placa e dificultando o isolamento de colônias de E. coli O157: H7 para testes confirmatórios (FAGUNDES et al. 2005). 
Considerando as limitações da técnica utilizada, é possível que a baixa taxa de isolamento de $E$. coli $\mathrm{O} 157: \mathrm{H} 7$ encontrada neste estudo no leite individual dos animais (média geral nas duas regiões: $1,3 \%$ ) tenha sido acarretada pela dificuldade de isolamento do agente em amostras de leite cru, devido à contaminação inicial elevada. Com relação ao leite de mistura, pode-se afirmar que a baixa freqüência encontrada nas amostras individuais contribuiu para que houvesse um efeito de diluição no leite de mistura, não sendo detectada a presença de E. coli O157: H7.

Com base nos resultados obtidos neste estudo, não é possível concluir se a $E$. coli O157: H7 é um potencial agente causador de mastite. É importante ressaltar, porém, que o delineamento experimental do trabalho não contemplou este objetivo, pois foram utilizadas amostras compostas de leite colhidas após a ordenha dos animais e não amostras individuais colhidas assepticamente dos quartos mamários. Entretanto, o isolamento de $E$. coli O157: H7 no leite de animais com mastite subclínica pode ser considerado como um importante indicador desta relação de causalidade, a qual necessita de confirmação através de estudos direcionados para esta finalidade. 


\section{CONCLUSÕES}

I. S. aureus e E. coli O157: $\mathrm{H} 7$ podem ser isolados do leite de vacas leiteiras sadias e de vacas com mastite subclínica, assim consideradas aquelas com leite contendo CCS abaixo ou acima de 200.000 céls. $/ \mathrm{mL}$, respectivamente.

II. A detecção de isolados de $S$. aureus enterotoxigênicos evidencia a existência do risco de veiculação de intoxicações decorrentes do consumo de leite e derivados.

III. Houve similaridade genética entre os isolados de $S$. aureus, de leites de uma mesma propriedade e entre propriedades distintas, indicando a dispersão epidemiológica deste agente entre os rebanhos leiteiros estudados.

IV. Propriedades leiteiras com volume de produção diária entre $400 \mathrm{~L}$ e $1.000 \mathrm{~L}$ apresentaram maior risco de veiculação de $S$. aureus através do leite.

V. As condições de manejo de ordenha (tipo de ordenhadeira, uso de luvas, pré e pós dipping, desinfecção de teteiras e tipo de sanitizante), diagnóstico de mastite (teste de caneca de fundo preto) e a contagem de células somáticas não apresentaram relação com a ocorrência de S. aureus e E. coli O157: H7 no leite.

VI. A contagem de células somáticas no leite de mistura apresentou-se, de modo geral, de acordo com o limite estabelecido pela IN 51, indicando boa capacidade de adequação dos produtores a este parâmetro.

VII. A contagem de aeróbios mesófilos no leite de mistura da maioria das propriedades ultrapassou o limite estabelecido pela IN 51, o que revela a existência de dificuldades enfrentadas pelos produtores para a obtenção de leite em condições higiênicosanitárias de acordo com a legislação em vigor. 


\section{REFERÊNCIAS}

ALMEIDA, R. A. K. R. et al. Staphylococcus aureus invasion of bovine mammary epithelial cells. J. Dairy Sci., Savoy, IL v. 79, n. 6, p. 1021-1026, 1996.

ALVES, A. et al. Tipagem genética de microrganismos. Disponível em:

$<$ http://sweet.ua.pt/ f426/posters/Manual\%20Metodos\%20de\%20Tipagem.pdf>. Acesso em: 11 de dez. 2006.

AMARAL, L. A. et al. Avaliação da eficiência da desinfecção de teteiras e dos tetos no processo de ordenha mecânica de vacas. Pesq. Vet. Bras., Rio de Janeiro, v. 24, n. 4, p.173-177, 2004.

AMMON, A. Surveillance of enterohaemorrhagic Escherichia coli (ECEH) infections and haemolytic uraemic syndrome (HUS) in Europe. Euro Surveill. Berlim, 2, 91-96, 1997. Disponível em: http://www.eurosurveillance.org/em/v02n12/0212-221.asp. Acessado em: Jul. de 2006.

ARAÚJO, W. P. et al. Staphylococcus aureus em leite cru. I. Contagem, verificação da enterotoxigenicidade e fagotipagem das cepas isoladas. Rev. Fac. Med. Vet. e Zoot. USP, São Paulo. v. 26, p. 187-198, 1989.

BAM - Bacteriological Analytical Manual. FDA/Center for Food Safety e Applied Nutrition. Disponível em: <http://www.cfsan.fda.gov/ ebam/bam-toc.html>. Acessado em: 10 de Mar. de 2001.

BABAK, V.; RYSANEK, D. Inter-laboratory trials milk cell counts: comparison of the Fossomatic and Somacount systems. Milchwissenschaft, v. 54, p. 126-128, 1999.

BALABAN, N.; RASOOLY, A. Staphylococcal enterotoxins: a review. Int. J. Food Microbiol, v. 61, p.1-10, 2000.

BANNERMAN, T. L. et al. Pulsed-field gel electrophoresis as a replacement for bacteriophage typing of Staphylococcus aureus. J. Clin. Microbiol., Washington, v. 33, n. 3, p. 551-555, 1995.

BENNETT, R. W. Atypical Toxigenic Staphylococcus and Non-Staphylococcus aureus Species on the Horizon? An update. J. Food Prot., Des Moines, v.59, p.1123-1126, 1996.

BERGDOLL, M. S. Staphylococcus aureus. In: DOYLE, M. P. Food-borne bacterial pathogens. New York: Marcel Dekker, p. 464-523. 1989.

BERQUÓ, E. S.; SOUZA, J. M. P.; GOTLIEB, S. L. D. Bioestatística. São Paulo: EPU, 1981.

BONE, F. J., BOGIE, D., MORGAN-JONES, S. C. Staphylococcal food poisoning from sheep milk cheese. Epidemiol Infect, Cambrigde, v.103, p.449-458, 1989.

BRABES, K. et al. Participação de espécies coagulase positivas e negativas produtoras de enterotoxinas de gênero Staphylococcus na etiologia de casos de mastite bovina em propriedades de produção leiteira dos estados de São Paulo e Minas Gerais. Rev. Napgama, São Paulo, v.3, p. 4-11, 1999. 
BRADLEY, A. J.; GREEN, M. J. A study of the incidence and significance of intramammary enterobacterial infections acquired during the dry period. J. Dairy Sci., Savoy, IL v. 83, p. 1957-1965, 2000.

BRASIL. Instrução Normativa 51, de 20 de setembro de 2002. Aprova os regulamentos técnicos de produção, identidade e qualidade do leite tipo... Diário Oficial da União, Seção I, p.13, 2002b.

BRITO, J. R. F. Contagem bacteriana da superfície de tetas de vacas submetidas a diferentes processos de higienização, incluindo a ordenha manual com participação do bezerro para estimular a descida do leite. Rev. Univ. Fed. Santa Maria, Santa Maria, v. 30, n. $5,2000$.

BRYAN, F. L. Staphylococcus aureus. In: DEFIGUEIREDO, M. P.; SPLITTSTOESSER, D. F. (eds.) Food Microbiology: public health and spoilage aspects. Westport: AVI Publishing, 1976. p. $12-128$.

CAPURRO, A. et al. Identification of coagulase positive Staphylococci isolated from bovine millk. Acta Vet. Scandinavia, v. 40, p. 315 - 321, 1999.

CARDOSO, H. F. T. et al. Detecção da toxina - 1 da síndrome do choque tóxico em amostras de Staphylococcus aureus isoladas de mastite bovina. Arq. Bras. Med. Vet. Zootec., Belo Horizonte, v. 52, p.7-10, 2000.

CARUSO, J. G. B.; OLIVEIRA, A. J. Leite: obtenção, controle de qualidade e processamento. Piracicaba: FEALQ, 1984. p. 47-61.

CDC - Centers for Disease Control and Prevention, EUA. Disponível em: www.cdc.gov. Acessado em: 13 de dez. de 2006.

CHAPAVAL, L. Detecção de enterotoxinas produzidas por Staphylococcus aureus no leite bovino por eletroforese capilar e identificação dos isolados enterotoxigênicos via PCR. 1999. 25 f. (Plano de doutorado) - Escola Superior de Agricultura Luiz de Queiroz, Universidade de São Paulo, Piracicaba, 1999.

CHRISTEN, G. L. Analyses. In: HUY, Y.H. Dairy science and technology handbook. New York: VCH Publishers, 1993. v. 1, p. 83-156.

COSTA, E. O. et al. Índices de mastite bovina clínica e subclínica nos Estados de São Paulo e Minas Gerais. Rev. Bras. Med. Vet. São Paulo, v. 17, n. 5, p. 215 - 217, 1995a.

et al. Estudo etiológico da mastite bovina. São Paulo. Rev. Bras. Med. Vet., São Paulo, v.17, p.156-158, 1995.

. et al. Mastite subclínica: prejuízos causados e os custos de prevenção em propriedades leiteiras. São Paulo. Rev. Napgama. São Paulo, v. 2, p.16-20, 1999.

et al. Infectious bovine mastitis caused by environmental organisms. J. Vet. Med. B., São Paulo, 45: 65-71, 1998.

COUSIN, M. A. Presence and activity psychotropic microorganisms in milk and dairy products. J. Food Prot, Des Moines, v. 45, p. 172, 1982.

CULLOR, J. S. The control, treatment and prevention of various types of bovine mastitis.

Vet. Med.. v. 88, p. 571-579, jun. 1993. 
CRUMP, J. A., et al. An Outbreak of Escherichia coli O157: H7 Infections among visitors to a Dairy Farm. The New Eng. J. Med. Waltham, n. 8, v. 347, p. 555 - 560, 2002.

CVE - CENTRO DE VIGILÂNCIA SANITÁRIA DO ESTADO DE SAO PAULO. Disponível em: <http://www.cve.saude.sp.gov.br>. Acesso em: 12 de dez. 2006.

DE FREITAS, M. A. Q.; MAGALHÃES, H. Enterotoxigenicidade de Staphylococcus aureus isolados de vacas com mastite. Rev. Microbiol., v. 21, p. 315-319, 1990.

DESMASURES et al., Monitoring the microbiology of high quality milk by monthly sampling over 2 years. J. Dairy Res, Cambridge, v. 64, p. 271-280, 1997.

DOPFER, D. et al. Recurrent clinical mastitis caused by Escherichia coli in dairy cows. J. Dairy Sci., Savoy, 82: 80-85, 1999.

DUNN, C. Acute coliform mastitis in a dairy cow. Can. Vet. J., Ottawa, v 35: 301-302. 1994.

DÜRR, J. W. Controle da qualidade e aumento da competitividade da indústria láctea. In: Tendências e avanços do agronegócio do leite nas Américas: Mais leite = Mais saúde. Montevidéu: FEPALE; Juiz de Fora: Embrapa Gado de leite; Porto Alegre: Associação Gaúcha dos Laticinistas, 2006. 96 p.

EBERHART, R. J. Coliform Mastitis. Vet. Clinics North Am., v. 6, p. 287-300, 1984.

EBLING, T. L. et al. Bovine mammary immune response to an experimental intramammary infection with a Staphylococcus aureus strain containing a gene for staphylococcal enterotoxin C1. J. Dairy Sci. Savoy, 84, 2044-2050. 2001.

EDMONDSON, P. W. Estratégias para a produção de leite de alta qualidade. In: CONGRESSO PAN-AMERICANO DE QUALIDADE DO LEITE E CONTROLE DE MASTITE, 2002, São Paulo. Anais... São Paulo: Instituto Fernando Costa, 2002. 198 p.

EDWARDS, P. R.; EWING, W. H. Identification of enterobacteriaceae. Mineapolis: Burgess Publishing Company, 1972.

ELLIS, J. A., GODSON, D., CAMPOS, M. Capture immunoassay for ruminant tumor necrosis factor - alpha: comparison with bioassay. Vet Immunol Immunopathol, v.35, p.289-300, 1993.

ERSKINE, R. J. J. et al. Theory, use, and realities of efficacy and food safety of antimicrobial treatment of acute coliform mastitis. J. Am. Vet. Med. Assoc. Schaumburg, v. 198, p. 980984. 1991.

EVENSON, M. L., HINDS, M. W., BERNSTEIN, R. S. Estimation of human dose of staphylococcal enterotoxin A from a large outbreak of staphylococcal food poisoning involving chocolate milk. Int. J. Food Microbiol, v. 7, p. 311-316, 1988.

FAGUNDES, $\mathrm{H}$.; et al. Uso do telurito de potássio como agente eletivo no isolamento de Escherichia coli O157: $\mathrm{H} 7$ em leite in natura. In: XXIII CONGRESSO BRASILEIRO DE MICROBIOLOGIA, Sociedade Brasileira de Microbiologia, 2005, Santos. Anais... Santos, 2005. 
FARIA, V. P. Qualidade: um tema atual para o futuro do leite. Rev. Balde Branco, v. 405, p.20-26, 1998.

FERREIRA, L. M. Variabilidade fenotípica e genotípica das estirpes de Staphylococcus aureus isoladas dos casos de mastite subclínica bovina. 2004. 28 f. Dissertação (Mestrado) - Universidade Estadual Paulista, Jaboticabal, 2004.

FONSECA, L. F. L. Estudo da prevalência da mastite bovina e sua relação com práticas de manejo, higiene e terapia em fazendas produtoras de leite tipo B no Estado de São Paulo. 1992. 148 f. Dissertação (Mestrado) - Universidade de São Paulo, ESALQ, Piracicaba, 1992.

FONSECA, L. F. L.; SANTOS, M. V. Qualidade do leite e controle de mastite. São Paulo: Lemos Editorial, 2000. 175p.

FORSYTHE, S. J. Microbiologia da segurança alimentar. Porto Alegre: Artmed, 2002. 424 p.

FRENAY, H. et al., Molecular typing of methicillin-resistant Staphylococcus spp. On the basis of protein A gene polymorphism. Eur. J. Clin. Microbiol. Infect. Dis. v. 15, p. 60 - 64, 1996.

GANDRA, E.A. et al. Biochemical differentiation among S. aureus, S. intermedius and S. hyicus isolated from bovines with subclinical mastitis. Arch. Vet. Sci, Curitiba, v. 10, n. 1, p. 75-81, 2005.

GENIGEORGIS, C. A. Present state of knowledge on staphylococcal intoxication. Int. J. of Food Microbiol., v. 9, p. 327-360. 1989.

GILMOUR, A.; HARVEY, J. Staphylococci in milk and milk products. J. Applied Bacteriol, Symposium Supplement 19, 147 S - 166 S. 1990.

GUERREIRO, P. K. et al. Qualidade microbiológica de leite em função de técnicas profiláticas no manejo de produção. Ciênc. agrotec., Lavras, v. 29, n. 1, p. 216-222, 2005.

GUIA ALIMENTAR PARA A POPULAÇAO BRASILEIRA. Brasília: Ministério da Saúde, 2006. 210 p. Disponível em: www.saude.gov.br/nutricao. Acessado em: 13 de Dez. de 2006.

GODDEN, S. M. et al., The effect of sampling time and sample handling on the detection of Staphylococcus aureus in milk from quarters with subclinical mastitis. Can. Vet. J. Ottawa, v. 43, p. 38- 42, 2002.

GOLDBERG, J. J.; MURDOUGH, P. A.; HOWARD, A. B.; DRECHSLER,P. A. Evaluation of a 1 percent iodophor post milking teat sanitizer. J. Dairy Sci., Savoy, v.77, n.33, p.740-747, 1994.

HARMON, R. J. Physiology of mastitis and factors affecting somatic cell counts. J. Dairy Sci, Savoy, v.7, p.2103-2112, 1994.

HILLERTON, J. E. Controle da mastite bovina. In: BRITO, J.R. F., BRESSAN, M., (ed).

Controle integrado da mastite bovina. Juiz de Fora: Embrapa - CNPGL, 1996. p.10-52.

HINTON, M.; BALE, M. J. Bacterial pathogens in domesticated animals and their environment. J. Applied Bact. Symposium supplements 70: 81 S- 90 S, 1991. 
HUNTER, P. R.; GASTON, M. A. Numerical index of discriminatory ability of typing systems: an application of Simpson's index of diversity. J. Clin. Microbiol., Washington, v.26, p.24652466, 1988.

IGARASHY, $\mathrm{H}$. et al. Latex agglutination test for staphylococcal toxic shock syndrome toxin 1. J. Clin. Microbiol. Washington, v. 23, p. 509 - 512. 1986.

JAY, J. M. Microbiología moderna de los alimentos. Zaragoza: Acribia, 1994. 804p.

JAYARAO, B. M., HENNING, D. R. Prevalence of food borne pathogens in bulk tank milk. J. Dairy Sci. Savoy, v. 84, p. 2157 - 2162. 2001.

JAYARAO, B. M. et al., Guidelines for monitoring bulk tank milk somatic cell and bacterial counts. J. Dairy Sci. Savoy, v. 87, n. 10, p. 3561-3573, 2004.

JAYARAO, B. M., WANG, L. A study on the prevalence of gram-negative bacteria in bulk tank milk. J. Dairy Sci. Savoy, v. 82, p. 2620-2624. 1999.

JEKEL, J. F. et al., Epidemiologia, Bioestatística e Medicina Preventiva. ArtMed, Porto Alegre, 1999. $200 \mathrm{p}$.

JONES, G. M. Milking practices recommended to assure milk quality and prevent mastitis. Dairy Science, Virginia Cooperative Extension, p.404-227, 1998.

JONES, T.O., WIENEKE, A.A. Staphylococcal toxic shock syndrome. Vet Rec, Londres v.119, p.435, 1986.

KAPUR, V. Molecular population genetic analysis of Staphylococcus aureus recovered from cows. J. Clin. Microbiol. Washington, v. 33, p. 376-380, 1995.

KATSUYA, E. M., LERNER, L. H. Escherichia coli O157: H7, um enteropatógeno emergente. Revista CIP, São Paulo, n.1, set. 1998. Disponível em: <http://www.cip.saude.sp.gov.br>. Acesso em: 10 de out. de 2006.

KENNY, K. et al., Production of enterotoxins and toxic shock syndrome toxin by bovine mammary isolates of Staphylococcus aureus. J. Clin. Microbiol, Washington, v.31, p.796707, 1993.

KLIE, H. M. et al., Detection and occurrence of verotoxin-forming and or shigatoxin producing Escherichia coli (VTEC and/or STEC in milk). Berl. Munch. Tierarzlt. Wochenschr. V. 110, p. 337-341. 1997.

LAMAITA, H. C. et al., Contagem de Staphylococcus sp. e detecção de enterotoxinas estafilocócicas e toxina da síndrome do choque tóxico em amostras de leite cru refrigerado. Arq. Bras. Med. Vet. Zootec, Belo Horizonte, v. 57, n. 5, p. 702-709, 2005.

LANGE C. C.; BRITO, J. R. F. Influencia da qualidade do leite na manufatura e vida de prateleira dos produtos lácteos: papel das altas contagens microbianas. In: Diagnostico da qualidade do leite, impacto para a indústria e a questão dos resíduos de antibióticos. Juiz de Fora: Embrapa Gado de Leite; EPAMIG/CT/ILCT, 2003. 168 p.

LANGE, C. et al. Molecular sub typing of Staphylococcus aureus isolates from cases of bovine mastitis in Brazil. Vet. Microbiol., Amsterdam, v.67, p.127-141, 1999. 
LANGENEGGER, B., COELHO, N. M., LANGENEGGER, C. H. Estudo da incidência de mastite bovina na bacia leiteira do Rio de Janeiro. Pesq. Agropec. Bras, Brasília, v.5, p.437, 1970.

LANGONI, H. et al. Aspectos etiológicos na mastite bovina. Rev. Bras. Med. Vet, v.20, p.204-210, 1998.

LOPES, C. A. M. et al. Characteristics of Staphylococcus aureus from subclinical bovine mastitis in Brazil. Braz. Vet. J., São Paulo, v. 146, p. 443-448, 1990.

MACHADO, P. F. et al. O panorama da qualidade do leite na Região Sudeste - São Paulo. In: Diagnóstico da qualidade do leite, impacto para a indústria e a questão dos resíduos de antibióticos. Juiz de Fora: Embrapa Gado de Leite; EPAMIG/CT/ILCT, 2003. 168 p.

MARIANO, F. A. et al. Cepas de Staphylococcus spp enterotoxigênicos isolados de leite caprino. Isolamento e identificação automatizada de cepas de Staphylococcus spp enterotoxigênicos oriundos de leite caprino. In: ENCONTRO DE INICIAÇÃO CIENTÍFICA, 7, 2002. Campos dos Goytacazes, RJ. Anais... Campos dos Goytacazes: Universidade Estadual do Norte Fluminense, 2002.

MASSA, S. et al. Fate of Escherichia coli $\mathrm{O} 157$ : $\mathrm{H} 7$ in unpasteurized milk stored at $8^{\circ} \mathrm{C}$. Letters in Applied Microbiol. v. 28, p. 89-92, 1999.

MASUD, T. et al. Enterotoxigenicity of Staphylococcus aureus isolated from dairy products. Aust. J. Dairy Technol, n. 48, p. 30-32, 1993.

MATSUNAGA, T., et al. Characteristics of Staphylococcus aureus isolated from peracute, acute and chronic bovine mastitis. J. Vet. Med. Sci, v. 55, p. 297-300, 1993.

McDOUGAL, L. K. et al. Pulsed-Field Gel Electrophoresis Typing of Oxacillin-Resistant Staphylococcus aureus isolates from the United States: Establishing a National Database. J. Clin. Microbiol., Washington, v. 41, n. 11, p. 5113-5120, 2003.

MILTENBURG, J. D. et al. Incidence of clinical mastitis in a random sample of dairy herds in the southern Netherlands. Vet. Rec., Londres, 139: 204-207, 1996.

MINISTÉRIO DA SAÚDE. Sistema de Informações Hospitalares - DATASUS, Ministério da Saúde, 1999.

MONARDES, H. Reflexões sobre a qualidade do leite. In: O compromisso com a qualidade do leite no Brasil. Passo Fundo. Ed. Universitária - Universidade de Passo Fundo. 2004. $331 \mathrm{p}$.

MURRAY, P. R. et al. Medical Microbiology. 3th ed. Mosby-Year Book. p. 175-188. 1998.

NATIONAL MASTITIS COUNCIL Current concepts of bovine mastitis. 4 ed. Madison : NMC, 1996. 64p.

NERO, L. A. et al. Leite cru de quatro regiões leiteiras brasileiras: Perspectivas de atendimento dos requisitos microbiológicos estabelecidos pela Instrução Normativa 51.

Ciênc. Tecnol. Aliment., Campinas, n. 25 v. 1, p. 191-195, 2005.

NG, D. L. K., TAY, L. Enterotoxigenic strains of coagulase-positive Staphylococcus aureus in drinks and ready to eat foods. Food Microbiol, v.10, p.317-320, 1993. 
PANKEY, J. W. Hygiene at milking time in the prevention of bovine mastitis. British Vet. J., v. 145, p. 401-409, 1989.

PEDRINI, S. C. B.; MARGATHO, L. F. F. Sensibilidade de microrganismos patogênicos isolados de casos de mastite clinica em bovinos frente a diferentes tipos de desinfetantes. Arq. Inst. Biol. São Paulo, v. 70, n. 4, p. 391-395, 2003.

Philpot W. N. e Nickerson S. C. Mastitis: counter attack. Babson Bros, Naperville. 150p. 1991.

PEREIRA, M. L. et al. Comportamento de estafilococos coagulase negativos pauciprodutores de enterotoxinas em alimentos experimentalmente inoculados. Ciênc. Tecnol Aliment, Campinas, v. 21, p. 171-175, 2001.

PRATA, L. F. Fundamentos de ciência do leite. São Paulo: Unesp, 1998. 119 p.

RADOSTITS, O. M.; GAY, C. C. BLOOD, D. C. Veterinary Medicine. A textbook of the diseases of cattle, sheep, pigs, goats, and horses. 9. ed. London: W. B. Saunders, 2000. p. 603-700.

REFAI, M. et al. Correlation between antibiotic resistance, enterotoxigenicity and enzimatic activities of Staphylococcus aureus recovered from foods. Vet. Med. J, v. 36, p. 107-109, 1998.

RISTOW, L.E. e PEREZ JUNIOR, A. A. Mastite: interpretação dos resultados de análises microbiológicas e antibiograma (Parte II). Rev. Tecn. da Bov. de leite, v. 1, n. 3, p. 51-55. 2006.

ROBERSON, J.R. et al., Ecology of Staphylococcus aureus isolated from various sites on dairy farms. J. Dairy Sci. Savoy, v. 77, p. 3354-3364, 1994.

ROBERSON, J.R. et al. Evaluation of methods for differentiation of coagulase-positive staphylococci. J. Clin. Microbiol. Washington, v. 30, p. 3217-3219, 1992.

ROSEC, J.P. et al. Enterotoxin production by staphylococci isolated from foods in France. Int J Food Microbiol, v.35, p.213-221, 1997.

SÁ, M. E. P. et al. Importância do Staphylococcus aureus nas mastites subclínicas: pesquisa de enterotoxinas e toxina do choque tóxico, e a relação com a contagem de células somáticas. Braz. J. Vet Res. Anim. Sci. São Paulo, v. 41, p. 320-326. 2004.

SANT'ANA, A. S. et al. Comparação entre os métodos rápidos Simplate TPC - Cl e Petrifilm AC e os métodos convencionais de contagem em placas para a enumeração de aeróbios mesófilos em sorvetes. Ciênc. Tecnol. Aliment., Campinas, 22 v. 1, p. 60-64, 2002.

SANTOS, M. V.; FONSECA, L. F. L. Importância e efeito de bactérias psicrotróficas sobre a qualidade do leite. Rev. Hig. Alim., São Paulo, v. 15, n. 82, p. 13-19, 2001.

SANTOS, F. G. B. et al. Tipagem molecular de Staphylococcus aureus isolados do leite de vacas com mastite subclínica e equipamentos de ordenha procedentes do estado de Pernambuco. Rev. Napgama. São Paulo, v. 6, n. 1, p. 19-23, 2003. 
SCHALM, O. W.; NOORLANDER, D. O. Experimental and observation lading to development of California mastitis test. J. Am. Vet. Med. Assoc., Schaumburg, v. 130, n. 5, p. 199 - 204, 1957.

SCHMITT, A. Influência das bactérias sobre a qualidade do leite. Disponível em: http://www.upf.br). Acessado em 08 de outubro de 2003.

SENA, M. J. Perfil epidemiológico, resistência de antibióticos e aos conservantes nisinalactoperoxidase de Staphylococcus spp. isolados de queijos coalho comercializados em Recife-PE. 2000 Tese (Doutorado) - Instituto de Veterinária da UFMG Belo Horizonte. 2000.

SHPIGEL, N. Y. et al. Clinical, bacteriological and epidemiological aspects of clinical mastitis in Israeli dairy herds. Prev. Vet. Med. v. 35 n. 1, p. 1-9, 1998.

SILVA, N., et al. Occurrence of Escherichia coli O157: $\mathrm{H} 7$ in meat products and sensibility of the detection methods. Ciênc. Tecnol. Aliment. Campinas, v. 21, n. 2, p. 223-227. 2001.

SILVA, N.; et al. Manual de métodos de análise microbiológica de alimentos. 2 ed. São Paulo: Livraria Varela, 2001.

SILVEIRA, T. M. L. et al. Comparação entre o método de referência e a análise eletrônica na determinação da contagem de células somáticas do leite bovino. Arq. Bras. Med. Vet. Zootec., São Paulo v. 57, n. 1, p.128-132, 2005.

SMITH, J. L. et al. Effect of environment on staphylococcal enterotoxin synthesis: a review. J Food Prot., Des Moines, v. 46, p. 545-555, 1983.

SMITH, K. L. e HOGAN, J. S. Environmental mastitis. Vet. Clinics North Am. Food Anim Pract., v. 9, p. 489- 498, 1993.

SMITH, K. L. et al. National Mastitis Council guidelines on normal and abnormal raw milk based on somatic cell counts and signs of clinical mastitis. Disponível em:

http://www.nmconline.org/docs/abmilk.pdf. 2001.

STEELE, M.L. et al., Survey of Ontario bulk tank milk for food borne pathogens. J. Food Prot. Des Moines, v. 60, p. 1341-1346, 1997.

STEPHEN, R.; KUHN, K. Prevalence of verotoxin - producing Escherichia coli (VTEC) in bovine coli mastitis and their antibiotic resistance patterns. J. Vet. Med. v. 46, p. $423-427$, 1999.

TAKEUCHI, S., et al. Production of toxic shock syndrome toxin by Staphylococcus aureus isolated from mastitic cow's milk and farm bulk tank. Vet Microbiol, v. 59, p. 251-258, 1998.

TAVERNA, M. Reflexões sobre a qualidade do leite. In: O compromisso com a qualidade do leite no Brasil. Passo Fundo. Ed. Universitária - Universidade de Passo Fundo. 331 p. 2004.

TONDO, E. C. et al. Assessing and analyzing contamination of a dairy products processing plant by Staphylococcus aureus using antibiotic resistance and PFGE. Can. J. Microbiol. Ottawa, v. 46, p. 1108 - 1114, 2000.

TENOVER, F. C. et al. Comparison of traditional and molecular methods of typing isolates of Staphylococcus aureus. J. Clin. Microbiol., Washington, v.32, p.407, 1994. 
VALLE, J., GOMEZ-LUCIA, E., PIRIZ, S., Enterotoxin production by staphylococci isolated from healthy goats. Appl. Environ. Microbiol, v.56, p.1323-1326, 1990.

WATANABE, E. T. Avaliação do uso de antibióticos por via intramamária e sistêmica no tratamento de mastite clínica em vacas em lactação e subclínica na interrupção da lactação. São Paulo, 1999. 121p. Dissertação (Mestrado) - Instituto de Ciências Biomédicas Universidade de São Paulo, 1999.

YI, C. S., LEE-WONG, A. C. Current perspectives on detection of staphylococcal enterotoxins. J Food Prot., Des Moines v.60, p.195-202, 1997.

YOUNIS et al. Staphylococcus aureus Exosecretions and Bovine Mastitis. J. Vet. Med. n. 1, v. 50 , p. 1, 2003.

ZECCONI, A., HAHN, G. Staphylococcus aureus in raw milk and human health risk. Bulletin of IDF, v.345, p.15-18, 2000. 
ANEXO 1 